\title{
Bibliografia historii wychowania, szkolnictwa i myśli pedagogicznej w Polsce za rok 2016 ( $\mathrm{z}$ uzupelnieniami za lata poprzednie)
}

DOI: $10.14746 /$ bhw.2017.37.13

\begin{abstract}
Wstęp
Bibliografia rejestruje druki zwarte, artykuły z czasopism i prac zbiorowych, wydane w 2016 roku oraz pozycje z lat wcześniejszych, które nie zostały ujęte w poprzednich częściach bibliografii, zamieszczanych na łamach Biuletynu Historii Wychowania od 2002 roku. Nie uwzględniono recenzji, opublikowanych w 2016 roku, a dotyczących publikacji zarejestrowanych we wcześniejszych częściach bibliografii. Bibliografia ma układ według podanego niżej schematu. W poszczególnych działach i poddziałach (z wyjątkiem poddziału 5. Szkoły wyższe w Dziale III, gdzie zastosowano układ według nazw szkół oraz poddziału 2. Poszczególne biografie w Dziale IV, w którym pozycje ułożone zostały według nazwisk osób) zastosowano układ alfabetyczny według haseł autorskich lub tytułowych. Opisy w razie potrzeby zostały uzupełnione adnotacjami, a w przypadku prac zbiorowych wyszczególniono składające się na nie artykuły, dotyczące historii oświaty i wychowania.
\end{abstract}

Schemat układu bibliografii:

I. Opracowania ogólne. Bibliografie

II. Rozwój oświaty, wychowania i myśli pedagogicznej

1. Opracowania ogólne

2. Okres do 1795 roku

3. Okres $1795-1918$

4. Okres 1918-1939

5. Okres 1939-1945

6. Okres 1945-1989

7. Okres 1989-2016

8. Oświata polonijna

III. Dzieje szkół różnych stopni

1. Szkoły podstawowe i zakłady wychowawcze

2. Szkoły ponadpodstawowe ogólnokształcące

3. Szkoły zawodowe

4. Zakłady kształcenia nauczycieli (z wyjątkiem szkół wyższych)

5. Szkoły wyższe 
IV. Biografie

1. Zbiory życiorysów

2. Poszczególne biografie

V. Dzieje oświaty pozaszkolnej

1. Oświata dorosłych

2. Biblioteki

VI. Dzieje ruchu nauczycielskiego

1. Opracowania ogólne

2. Pamiętniki nauczycieli

VII. Organizacje młodzieżowe

1. Harcerstwo

2. Inne 


\section{OPRACOWANIA OGÓLNE. BIBLIOGRAFIE}

1. APANEL Danuta, Dąbrowska Joanna E.: Sprawozdanie z VI Walnego Zebrania Towarzystwa Historii Edukacji, Warszawa, 14 stycznia 2016 roku. Przegląd Historyczno-Oświatowy. R. 59: 2016 nr 3/4 s. 288-292.

2. BARABAS Magdalena: Wartości w życiu i spuściźnie pedagogicznej Janusza Korczaka. Roczniki Teologiczne. T. 63: 2016 s. 91-204.

3. BEDNARZ-GRZYBEK Renata: Kwestia kobieca. Rodzina, wychowanie, edukacja. Bibliografia adnotowana zawartości czasopisma „Bluszcz”(wybór za lata 1865-1905). Lublin 2016 Wydaw. UMCS ss. 274.

4. BOUŻYK Maria M.: Wychowanie otwarte na religię na podstawie wybranych prac Jacka Woronieckiego [1878-1948]. [W:] Pedagogika wobec duchowości - duchowość wobec pedagogiki. Praca zbiorowa. Pod red. Zbigniewa Babickiego i Dariusza Stępkowskiego. Warszawa 2016 s. $77-114$.

5. BOUŻYK M. M.: Uczeń czy książka? Pedagogika Jacka Woronieckiego [1878-1959] jako podpowiedź dla współczesnych systemów wychowawczych. Forum Pedagogiczne. 2016 nr 2 cz. 1 s. 229-243.

6. CHMURA-RUTKOWSKA Iwona, Głowacka-Sobiech Edyta, Skórzyńska Izabela: Sprawozdanie z Międzynarodowej Konferencji Naukowej „Szkolna edukacja historyczna. Historia ludzi. Historia dla ludzi”. Poznań, 25-26.10.2012 r. Studia Edukacyjne. Nr 22: 2012 s. 376-379.

7. CUKRAS-STELĄGOWSKA Joanna: Sprawozdanie z konferencji naukowej pt. „Pamięć w pedagogice" (Toruń, 1-2.03.2016). Acta Universitatis Nicolai Copernici. Nauki Humanistyczno-Społeczne. Z. 426: Pedagogika. Z. 435: 2016 [nr] 32 s. 231-235.

8. FILOZOFIA życia profesora Kazimierza Denka (1932-2016). Red. Aleksandra Kamińska, Ewa Kraus, Piotr Oleśniewicz. Sosnowiec 2016 Wyższa Szkoła Humanitas. Oficyna Wydawnicza Humanitas ss. 240, il. (Edukacja Jutra; 4).

Treść: Lewandowski Marek: Wstęp. O czasie podróży przez życie i poszukiwaniu prawdy s. 9-16; Ćwikliński Andrzej, Piotrowski Eugeniusz: Wspomnienia o Profesorze zw. dr. hab. Kazimierzu Denku [1932-2016] s. 19-28; Jasiński Zenon: Credo pedagogiczne Kazimierza Denka s. 31-42; Duraj-Nowakowa Krystyna: Całościowość systemowa edukacji Kazimierza Denka s. 45-59; Kaliszewska Małgorzata: Projektowanie Życia szkic na kanwie książek Profesora Kazimierza Denka s. 63-74; Palka Stanisław: Podstawy dydaktyki akademickiej w ujęciu Kazimierza Denka s. 77-83; Kabat Małgorzata: Dostojeństwo i nowoczesność uniwersytetu. Pamięci Mistrza s. 87-100; Włoch Stanisława: Uniwersyteckie kształcenie nauczycieli w poglądach prof. zw. dr hab. Kazimierza Denka s. 103-111; Grzesiak Jan: W kontynuacji myśli naukowych Profesora Kazimierza Denka - w trosce o tożsamość i rozwój dydaktyki s. 115-134; Kocór Maria: Myśl Profesora Kazimierza Denka inspiracją naukowych dociekań i badań nad ,dziś i jutro" edukacji szkolnej s. 137-150; Szulc Bogdan M.: Patriotyzm i sprawność jako element pedagogiki Kazimierza Denka w odniesieniu do oficerów WP (ze wspomnień wspólnych dyskursów) s. 173-189; Neckar-Ilnicka Teresa: Krajoznawstwo i turystyka jako wyzwanie dla edukacji s. 191-206; Mamroł Andrzej: Zdrowie a sposoby spędzania czasu wolnego przez uczniów szkół podstawowych i gimnazjalnych s. 209-221; Czaja Ewa: Zatrzymać czas s. 225-229; Wiesner Wojciech: Profesor Kazimierz Denek - takiego go zapamiętam s. 233-236; Juř́ková Jana: Wspomnienie Pana Profesora Kazimierza Denka s. 239-240.

9. GLIER Joachim Paweł: Podstawy filozoficzne pedagogiki serca oraz psychologiczna koncepcja człowieka Marii Łopatkowej [1927-2016]. Przegląd Pedagogiczny. 2015 nr 2 s. 38-57. 
10. GOLA Beata, Pauluk Dorota: II Seminarium Polskiej Myśli Pedagogicznej „Realizm filozoficzny jako podstawa koncepcji i kierunków rozwoju polskiej myśli pedagogicznej”, Kraków, 29 kwietnia 2016 roku. Przegląd Historyczno-Oświatowy. R. 59: 2016 nr 3/4 s. 293-297.

11. GRABOWSKA-PIEŃKOSZ Dorota: Sprawozdanie z konferencji naukowej „Pamięć w pedagogice", Toruń 1-2 marca 2016. Studia Paedagogica Ignatiana. Vol. 19: 2016 [nr] 3 s. 283-287.

12. GRABOWSKA-PIEŃKOSZ D.: Sprawozdanie z konferencji naukowej pt. „Pamięć w pedagogice" (1-2 marca 2016, Toruń). Biuletyn Historii Wychowania. [Nr] 34: 2016 s. 221-225.

13. GRUCA Anna: Bibliografia historii wychowania, szkolnictwa i myśli pedagogicznej w Polsce za rok 2014 (z uzupełnieniami za lata poprzednie). Biuletyn Historii Wychowania. [Nr] 34: 2016 s. $159-219$.

14. GUMUŁA Teresa, Majewski Stanisław: Badania Profesora Stanisława Mauersberga (1924-2012) nad szkolnictwem w Polsce w XX stuleciu. Przegląd Historyczno-Oświatowy. R. 59: 2016 nr 3/4 s. $180-195$.

15. KAMIŃSKA Aneta: Report from the international conference: „Multidisciplinary academic conference on education, teaching and e-learning”, Prague, 16-17.10.2014. Studia Paedagogica Ignatiana. Vol. 17: 2014 s. 267-268.

16. KORCZAK Janusz: Carnet de Janusz Korczak. Avec des extraits de ses oeuvres litt,raires et pédagogiques. Choix de textes et traduction du polonais Zofia Bobowicz. Cracovie-Budapest 2016 Austeria; Musée de Varsovie ss. 147, nlb. 12, il.

17. KOSTKIEWICZ Janina: Humanistyczna pedagogika społeczna jako pogranicze i obszar wspólny z katolicką nauką społeczną. Szkic zagadnienia. Polska Myśl Pedagogiczna. Nr 2: 2016 s. $51-81$.

18. KRAWIEC Grzegorz: Wychowanie do czystości w Prawie Mojżeszowym. Roczniki Pedagogiczne. T. 8: $2016 \mathrm{nr} 3$ s. 101-119.

19. KULBAKA Jacek: Korczakian dilemmas in the pedagogical theory and practice. Rocznik Komisji Nauk Pedagogicznych. R. 68: 2015 s. 111-127.

20. KUNISZEWSKA Teresa Leonarda: Pedagogia i apostolstwo błogosławionej Bolesławy Lament (1862-1946). Lublin 2016 Tow. Nauk. KUL ss. 333, nlb. 3, il. Tow. Nauk. KUL. (Źródła Monografie; 435).

21. LEGUTKO Justyna: Promocja statusu rodziny i kobiety w pedagogicznych poglądach Aleksandra Wóycickiego [1878-1954]. Polska Myśl Pedagogiczna. Nr 2: 2016 s. 411-425.

22. MEISSNER Andrzej: Profesor Julian Dybiec - przedstawiciel krakowskiego środowiska naukowego historyków wychowania. Studia i Prace Pedagogiczne. Nr 1: 2014 s. 253-260.

23. MURAWSKA Ewa: Ojciec polskiej pedeutologii naukowej - Jan Władysław Dawid [1859-1914]. Re(interpretacja poglądów. Edukacja w Dyskursie. Nr 4: 2016 s. 7-20.

24. NAUKOWA wspólnota uczących się. XXX-lecie Letniej Szkoły Pedagogów przy Komitecie Nauk Pedagogicznych PAN. Praca zespołowa. Pod red. Ewy Bochno, Alicji Korzenieckiej -Bondar. Białystok 2016 Wydaw. Uniw. w Białymstoku ss. 535, nlb. 12, il.

Treść: Bochnio E., Korzeniecka-Bondar A.: Letnia Szkoła Młodych Pedagogów jako naukowa wspólnota uczących się - wprowadzenie s. 11-24; Cz. 1. Z okazji Jubileuszu s. 25-113; Cz. 2. Naukowa wspólnota LSMP z perspektywy Mistrza - uczestnika Letnich Szkół Młodych Pedagogów s. 115-288; Cz. 3. Letnia Szkoła 
Młodych Pedagogów w procesie wzrastania od magistra od samodzielnego pracownika nauki - bycie w drodze s. 289-323; Cz. 4. Naukowa wspólnota Letnich Szkół Młodych Pedagogów z perspektywy szkolniaków s. 325-352; Cz. 5. ...I powaga, i żarty s. 353-445; Cz. 6. Co „wypączkowało” ze wspólnoty Letnich Szkół Młodych Pedagogów s. 447-511; Cz. 7. Zakończenia nie będzie... s. 513-535.

25. OBRYCKA Małgorzata: Etyka niezależna Tadeusza Kotarbińskiego w świetle fenomenograficznych badań nad wychowaniem religijnym. Universitas Gedanensis. R. 27: 2015 t. 50 s. $73-76$.

26. OPIELA Maria: Rola miłości we wczesnym wychowaniu w systemie pedagogicznym Edmunda Bojanowskiego [1814-1871]. Społeczeństwo i Rodzina. 2016 nr 1 s. 155-169.

27. PIEKARSKI Marian: Polska „szkoła twórcza” Henryka Rowida [1877-1944]: implikacja dla rozwoju zawodowego. Lubelski Rocznik Pedagogiczny. Vol. 35: 2016 no 1 s. 274-282.

28. PUDŁOWSKI Tomasz: Idea uniwersytetu według Romana Dyboskiego [1883-1945]. Rocznik Komisji Nauk Pedagogicznych. T. 69: 2016 s. 155-173.

29. REALIZM filozoficzny Szkoły Lubelskiej jako podstawa pedagogiki. Polska Myśl Pedagogiczna. Nr 2: 2016 s. 103-311.

Treść: Maryniarczyk Andrzej: Antropologiczno-metafizyczne podstawy adekwatnej teorii wychowania w ujęciu twórców Filozoficznej Szkoły Lubelskiej s. 103-115; Mioduszewski Tomasz: Po co pedagogom metafizyka realistyczna? s. 117-124; Starnawski Witold: Czym jest realizm w pedagogii osoby? s. 125-134; Rembierz Marek: Realizm metafizyczny jako inspiracja myśli pedagogicznej. O refleksji antropologiczno-pedagogicznej Stefana Swieżawskiego [1907-2004] i jej znaczeniu dla teorii wychowania oraz analiz metapedagogicznych s. 135-174; Śleziński Krzysztof: Założenia realizmu ontologicznego i aksjologicznego w koncepcji wychowania Jacka Woronieckiego [1878-1949] s. 175-187; Ryk Andrzej: Wątki realizmu klasycznego w „Pedagogii polskiej” Władysława Seredyńskiego [1841-1893] czytane w perspektywie „Rozmyślań o wychowaniu” o. Mieczysława Alberta Krąpca [1921-2008] s. 189-197; Opiela Maria: Znamiona realizmu w koncepcji pedagogicznej Edmunda Bojanowskiego [1814-1871] oraz w podstawach procesu jej zmian adaptacyjnych i zachowania tożsamości s. 199-214; Boużyk Maria M.: Realizm filozoficzny Polskiej Szkoły Filozofii Klasycznej jako podstawa modelu wychowania otwartego na religię s. 215-229; Horowski Jarosław: Wstyd a rozwój moralny - o antropologicznych fundamentach neotomistycznej teorii wychowania moralnego s. 231-244; Sztaba Mariusz: Realizm doświadczenia etycznego u podstaw adekwatnych koncepcji wychowania moralnego, Refleksja w świetle personalizmu etycznego Karola Wojtyły [1920-2005] i jego uczniów s. 245-269; Kiereś Barbara: Personalizm w pedagogice s. 271-281; Mółka Janusz: Personalizm chrześcijański podstawą życiowego sukcesu s. 283-293; Tytko Marek Mariusz: Wychowanie moralne - kształcenie charakteru dziecka (ujęcie realistyczne) s. 295-310; Małdrzykowska Anna: Implikacje pedagogiczne realizmu filozoficznego Szkoły Lubelskiej s. 311-321.

30. ROTKIEWICZ Halina: Nadzwyczajny Zjazd Delegatów Polskiego Towarzystwa Pedagogicznego, Warszawa, 11 maja 2016 roku. Przegląd Historyczno-Oświatowy. R. 59: 2016 nr 1/2 s. $248-255$.

31. RÓŻAŃSKI Tomasz: Sprawozdanie z seminarium naukowego pt. „Wzbudzanie sił społeczeństwa wychowującego. 40 lat pedagogiki społecznej i socjologii edukacji w Toruniu" (Toruń, 4.04.1916). Acta Universitatis Nicolai Copernici. Nauki Humanistyczno-Społeczne. Z. 426: Pedagogika. Z. 435: 2016 [nr] 32 s. 237-239.

32. SAJDAK-MICHNOWSKA Eulalia: Antoniego Bolesława Dobrowolskiego [1872-1954] wizja ludności wykształconej. Zeszyty Naukowe Koszalińskiej Wyższej Szkoły Nauk Humanistycznych. Z. 14: 2015 s. 162-167. 
33. SAJDAK-MICHNOWSKA E.: Koncepcja organizacyjno-programowa gimnazjum w poglądach Antoniego Dobrowolskiego [1872-1954]. Zeszyty Naukowe Koszalińskiej Wyższej Szkoty Nauk Humanistycznych. Z. 12: 2013 s. 163-167.

34. SALEZJAŃSKA ars educandi. Red. Karolina Kmiecik-Jusięga, Bogdan Stańkowski. Kraków 2016 Akad. Ignatianum; Wydaw. WAM ss. 306.

Z treści: Kmiecik-Jusięga K., Stańskowski B.: Wstęp s. 7-9; Grządziel Dariusz: Wychowanie dobrych obywateli według systemu prewencyjnego s. 13-35; Szymańska Maria: Miłość wychowawcza i jej egzemplifikacja w myśli wybranych pedagogów w ciągu wieków s. 67-99; Wierzbicki Mirosław Stanisław: Wychowanie przez sport w szkolnictwie salezjańskim s. 101-118; Lubieniecka Małgorzata: Muzyka w początkach działalności salezjanów w Krakowie s. 121-139; Wierzbicki M. S.: Edukacja religijna w szkołach salezjańskich s. 179-198; Rayzacher-Majewska Aneta: Twórczość katechetyczna ks. Wincentego Zaleskiego SDB [1913-1983] i jej aktualność w dzisiejszej katechezie s. 199-233.

35. SARAN Jan: Biografia jako metoda badań pedagogicznych. Studia i Prace Pedagogiczne. Nr 3: 2016 s. 13-35.

36. STAWOSKA-JUNDZIŁŁ Bożena: Czy studentom pedagogiki potrzebna jest historia wychowania? Niepetnosprawność. Nr 22: 2016 s. 232-242.

37. STĘPKOWSKI Dariusz: Filozofia doświadczenia osobistego Stefana Pawlickiego [1839-1916] a pedagogika ogólna. Polska Myśl Pedagogiczna. Nr 2: 2016 s. 339-344.

38. SZALKIEWICZ Marek: Problematyka wychowania w koncepcji pedagogicznej Heliodora Muszyńskiego [ur. 1931]. Zeszyty Naukowe - Państwowa Wyższa Szkoła Zawodowa im. Witelona w Legnicy. $2016 \mathrm{nr} 4$ s. 93-105.

39. SZCZUPAŁ Bernadeta: Maria Grzegorzewska [1888-1967] o godności człowieka. W konfrontacji ze współczesnością. Lubelski Rocznik Pedagogiczny. Vol. 35: 2016 nr 3 s. 9-18.

Pedagogika specjalna.

40. SZMYD Kazimierz: Lwowska Szkoła Filozoficzna w rozwoju nauk o wychowaniu (1914-1939). Współtwórcy, dokonania, kontynuacje. Lubelski Rocznik Pedagogiczny. Vol. 35: 2016 no 4 s. $175-196$.

41. ŚLIWERSKI Bogusław: Recepcja i aplikacja pedagogiki oraz psychologii krytycznej. Polska Myśl Pedagogiczna. Nr 2: 2016 s. 19-49.

42. TRACZYKOWSKI Dominik: Cele nauczania w myśli Kazimierza Twardowskiego [1866-1938]. Roczniki Pedagogiczne. T. 82016 nr 1 s. 9-22.

43. WERBIŃSKI Ireneusz: Aktualność duchowego przesłania Janusza Korczaka. Ateneum Kampańskie. T. 164: 2015 s. 268-282.

44. WOKÓŁ badań biograficznych w andragogice. Red. nauk. Olga Czerniawska, Katarzyna Wypiorczyk-Przygoda. Łódź 2015 Wydaw. Akad. Humanist.-Ekonomicznej ss. 124.

Z treści: Czerniawska O.: Andragogika z perspektywy badań biograficznych s. 9-22; Gołębiowski Andrzej: Dialog jako forma budowania wychowawczej przestrzeni międzypokoleniowej s. 37-58; Sulik Monika: W ogrodach pamięci i zaroślach niepamięci, czyli o motywach spisywania swoich wspomnień s. 59-75; Szafarz Maciej: Niewykorzystany czas a rozumienie potrzeby służby w oczach dorosłych instruktorów ZHP s. 77-98;

45. Z BADAŃ nad tradycją polskiej pedagogiki. T. 1: Indywidualizm - Edukacja - Kolektywizm. Red. nauk. Elżbieta Magiera. Szczecin 2015 Wydaw. Nauk. Wydz. Humanist. Uniw. Szczecińskiego „Minerwa” ss. 172.

Treść: Magiera E.: Wstęp s. 7-14; Andrukowicz Wiesław: Wokół historycznego fenomenu szkoły i jej współczesnych wyzwań s. 15-36; Andrukowicz W.: Indywiduum oraz indywidualizacja w ujęciu retrospektyw- 
nym s. 37-63; Jankowski Robert: O nauczycielu w myśli pedagogicznej Lucjana Zarzeckiego (1873-1925) s. 63-89; Koźmian Danuta: S. Barbara Żulińska (1881-1962) i jej miejsce w polskiej myśli pedagogicznej i religijnej XX wieku s. 91-110; Magiera E.: Praca w zespole jako podstawowa kategoria wychowania państwowego w zreformowanej szkole powszechnej w Polsce międzywojennej s. 111-138; Król Joanna: Indywidualizm versus kolektywizm w teorii i praktyce wychowawczej Związku Młodzieży Polskiej (1948-1957) s. 139-155; Nowotniak Justyna: Nowe wyzwania dotyczące badań indywidualizmu i kolektywizmu w naukach o wychowaniu w kontekście przemian więzi społecznych s. 157-172.

Rec.: Głowacka-Sobiech Edyta, Biuletyn Historii Wychowania. [Nr] 34: 2016 s. 145-147.

\section{ROZWÓJ OŚWIATY, WYCHOWANIA I MYŚLI PEDAGOGICZNEJ}

\section{Opracowania ogólne}

46. ADAMCZAK Stanisław, Jastrzębski Cezary, Borys Andrzej: 200 lat tradycji wyższego szkolnictwa technicznego na ziemiach polskich. Kielce 2016 Jedność ss. 95, nlb. 1, il.

XIX-XXI w.

47. AKADEMICKI Szczecin. XVI-XXI wiek. Pod red. Piotra Niedzielskiego i Waldemara Tarczyńskiego. Szczecin 2016 Wydaw. Nauk. Uniw. Szczecińskiego ss. 270, il.

Treść: Włodarczyk Edward: Kilka uwag w związku z jubileuszem 70-lecia szkolnictwa ekonomicznego s. 9-11; Niedzielski Piotr, Tarczyński Waldemar: Słowo wstępne dziekanów s. 13-14; Gaziński Radosław: Pedagogium Książęce (lata 1544-1667) s. 15-46; Gut Paweł: Szczecińskie akademickie szkoły średnie w II połowie XVII i XVIII wieku s. 47-80; Gut P.: Budowa uczelni wyższych w Szczecinie pod koniec XIX i w I połowie XX wieku s. 81-106; Gut P.: Polskie początki akademickiego Szczecina (lata 1945-1955) s. 107-128; Gut P.: Dla gospodarki Szczecina i regionu. Szkoły wyższe w Szczecinie w latach 1955-1989/1990 s. 129-157; Gaziński R.: Droga do Uniwersytetu Szczecińskiego s. 159-185; Frąckowiak Piotr: Uczelnie Szczecina w III RP s. 187-212; Sawicki Kazimierz, Tarczyński W.: Wydział Nauk Ekonomicznych [Uniwersytetu Szczecińskiego] s. 213-225; Niedzielski P.: Subiektywne spojrzenie (dziekana) na Szczecińską Szkołę Ekonomiki Transportu i Ekonomiki Usług s. 227-233; Flejterski Stanisław, Sobczak Tomasz: Szkoły naukowe i mistrzowie w szczecińskim ośrodku nauk ekonomicznych w latach 1946-2016 s. 235-270.

48. BARTKOWIAK Edyta: Z historii opieki. Szpitale i zakłady zakonne dla dzieci w tradycji polskiej. Relacje. $2016 \mathrm{nr} 2$ s. 41-60.

XIII-XX w.

49. BIEŚ Andrzej Paweł: Jezuickie instytucje edukacyjne w Orszy 1773-1820. Studia Paedagogica Ignatiana. Vol. 19: 2016 [nr] 3 s. 15-34.

50. BURZYŃSKA-WENTLAND Lidia: Kształcenie i doskonalenie zawodowe nauczycieli języka ukraińskiego w województwie gdańskim (pomorskim) z perspektywy lat 1956-2010. Studia i Badania Naukowe - Ateneum Szkoła Wyższa w Gdańsku. R. 8: 2014 nr 1 s. 19-28.

51. [CHROBAK Dariusz, Zglińska Anna]: Monografia szkolnictwa w Czernikowie i okolicy. Historia szkolnictwa w gminie Czernikowo i promocja lokalnego dziedzictwa kulturowo-historycznego. Oprac. ... Toruń 2014 Pol. Wydawnictwa Reklamowe ss. 149, nlb. 1, il.

XVIII-XXI w.

52. CIEŚLIK Marian: Oświaty kaganek czyli Zarys dziejów oświaty w Gminie Tokarnia. Tokarnia 2015 Gm. Ośr. Kultury i Sportu ss. 230, il.

Lata $1790-2015$. 
53. HISTORIA starożytna na polskich uniwersytetach. Wczoraj, dziś i jutro. Red. Ryszard Kulesza. Warszawa 2016 Inst. Hist. UW; Stow. Historyków Starożytności ss. 237. (Akme. Studia Historica; nr 14/2016).

Materiały z konferencji, 5 grudnia 2015 r., Warszawa.

Treść: Kulesza R.: Wstęp s. 7-9; Kaczanowicz Wiesław: Katowicki ośrodek starożytniczy. Przeszłość teraźniejszość - przyszłość s. 11-18; Balbuza Katarzyna, Tatarkiewicz Anna: Historia antyku w Poznaniu teraźniejszość i przyszłość dydaktyki s. 19-27; Nawotka Krzysztof, Pawlak Małgorzata: Historia starożytna na Uniwersytecie Wrocławskim s. 29-34; Okoń Danuta: Historia starożytna na Uniwersytecie Szczecińskim - stan obecny s. 35-42; Słapek Dariusz: Rekonstrukcje, repliki, eksperyment... - odtwórstwo historyczne a dydaktyka historii starożytnej w Instytucie Historii UMCS w latach 2002-2015 s. 43-58; Janiszewska-Sieńko Daria: Miejsce historii starożytnej w kursach uniwersyteckich na Uniwersytecie Zielonogórskim s. 59-66; Szopa Adrian, Wilczyński Marek: Czy można promować nauczanie historii i kultury starożytnej w warunkach reformy szkolnictwa wyższego, realizacji Krajowych Ram Kwalifikacji i nauczania na odległość? Kilka doświadczeń z Katedry Historii Starożytnej Uniwersytetu Pedagogicznego im. KEN w Krakowie s. 67-85; Sprawski Sławomir: Historia starożytna na Uniwersytecie Jagiellońskim s. 87-95; Olbrycht Marek Jan: Historia starożytna na Uniwersytecie Rzeszowskim s. 97-103; Wolny Miron: Historia starożytna na Uniwersytecie Jana Kochanowskiego w Kielcach s. 123-132; Stępień Marek: Historia starożytna w Instytucie Historycznym Uniwersytetu Warszawskiego s. 133-154; Kompa Andrzej: Historia starożytna na Uniwersytecie Łódzkim - przeszłość, specyfika, perspektywy s. 155-198; Historia starożytna na polskich uniwersytetach. Książka korespondencyjna. Oprac. Sebastian Rajewicz s. 199-229; Bibliografia. Oprac. Anna M. Kruszyńska s. 231-237.

54. JAKUBIAK Krzysztof, Jamrożek Wiesław: Dziejowe konteksty oraz tendencje reform szkolnych na ziemiach polskich od XVIII do XX wieku (do 1939 roku). Studia Edukacyjne. Nr 32: 2014 s. 7-19.

55. JAROWIECKI Jerzy: Czasopisma dla dzieci i młodzieży oraz prasa młodzieżowa w Polsce w latach 1918-2000. Wrocław 2016 Wydaw. Wyższej Szkoły Zarządzania „Edukacja” ss. 311, il. (Monografie Wyższej Szkoły Zarządzania „Edukacja” we Wrocławiu).

56. KĄKOL Barbara: Zaczarowany świat dziecka. Gry i zabawki na Kaszubach. Kartuzy 2016 Muzeum Kaszubskie im. Franciszka Tretera; Tow. Muzeum Kaszubskiego im. F. Brzezińskiego ss. 30, il. Muzeum Kaszubskie im. Franciszka Tretera; Tow. Muzeum Kaszubskiego im. F. Brzezińskiego.

Wystawa; Kartuzy, Muzeum Kaszubskie, 1-18 VI 2016 r.

57. KOSMALSKA Beata: Początki organizowania opieki nad dzieckiem w Europie i Polsce. Zeszyty Naukowe Gdańskiej Szkoty Wyższej. Nr 13: 2013 s. 325-338.

58. KOWALIŃSKA Anna, Paszkowski Wiesław: Z dziejów opieki nad dzieckiem żydowskim w Częstochowie. Prace Naukowe Akademii im. Jana Dlugosza. Pedagogika. T. 24: 2015 s. 599-616.

XIX-XX w.

59. KOWALSKI Stanisław: Szkice do dziejów oświaty i szkolnictwa na terenie Gminy Sieciechów. Sieciechów-Kozienice 2016 Stanisław Kowalski; Tow. Miłośn. Ziemi Kozienickiej ss. 112, il.

Lata $1687-2015$.

60. KROWICKI Stanisław Ludwik: Spacerkiem po dziejach polskiej edukacji. (Wybór artykułów publicystycznych). Kielce 2016 Wydaw. Pedagog. ZNP ss. 289.

61. KRÓLIKOWSKA Anna: Pamięć szkoły w czasopismach chyrowskich. Acta Universitatis Nicolai Copernici. Nauki Humanistyczno-Społeczne Z. 426: Pedagogika. Z. 435: 2016 [nr] 32 s. $50-70$.

XIX-XX w. 
62. KRZEŚNIAK-FIRLEJ Danuta, Firlej Stanisław: Szkolnictwo wyższe w Polsce w pierwszej połowie XX stulecia - zarys dziejów, przemiany i organizacja. Studia Pedagogiczne. T. 26: 2015 s. $35-56$.

Lata $1915-1939$.

63. KUREK-KOKOCIŃSKA Stanisława: Studia bibliotekoznawcze w Polsce. Historia i ewolucja w latach 1945-2015 ze szczególnym uwzględnieniem przykładu Uniwersytetu Łódzkiego. Łódź 2016 Wydaw. UŁ ss. 202, il. (Bibliologia - Kształcenie Pracowników Książki i Informacji).

64. ŁAPOT Mirosław: Placówki wychowania przedszkolnego we Lwowie do roku 1939. Przegląd Historyczno-Oświatowy. R. 59: $2016 \mathrm{nr}$ 1/2 s. 63-87.

XIX-XX w.

65. ŁAPOT M.: Szkolnictwo żydowskie we Lwowie (1772-1939). Częstochowa 2016 Wydaw. im. Stanisława Podobińskiego Akad. im. Jana Długosza ss. 591. Akad. im. Jana Długosza w Częstochowie.

66. MAMES Tomasz Dariusz: Oświata mariawitów w latach 1906-1935. Warszawa 2016 Wydaw. DiG; Bellerive-sur-Allier; Edition La-Rama ss. 302, nlb. 2, il. PTH.

67. MARKIEWICZOWA Hanna: Rzecz o Polskiej Macierzy Szkolnej. Warszawa 2016 Wydaw. Akad. Pedagogiki Specjalnej ss. 296, il.

W 1. 1906-1940.

Rec.: Grabowska-Pieńkosz: Z badań nad przeszłością polskich towarzystw społeczno-oświatowych na marginesie książki ... Studia Paedagogica Ignatiana. Vol. 19: 2016 [nr] 3 s. 273-280.

68. MIKLER-CHWASTEK Anna: Opieka nad małym dzieckiem dawniej i dziś. Prace Naukowe Akademii im. Jana Dtugosza. Pedagogika. T. 25: 2015 nr 2 s. 537-548.

69. MIŜIŠIN İrina: Kul'turno-osvìtnâ diâl'nìst' tovaristva „Zorâ” u L'vovì (1884-1939). Prace Naukowe Akademii im. Jana Dlugosza. Pedagogika. T. 25: 2015 nr 2 s. 423-433.

70. NAMENANIK Janusz: Z dziejów dzierżoniowskiego szkolnictwa. Prowincja. $2016 \mathrm{nr} 3$ s. $129-138$.

XIX-XX w.

71. NAWROT-BOROWSKA Monika, Małek Agnieszka: Wychowanie zdrowotne i higiena dzieci i młodzieży w świetle poradników dla rodziców z lat 1850-1970. Zarys problematyki. Przegląd Pedagogiczny. 2015 nr 2 s. 85-124.

72. NOWACKI Leszek: Sokoły wrzesińskie 1894-1939. Września 2016 Muzeum Region. im. Dzieci Wrzesińskich ss. 208, il. Muzeum Region. im. Dzieci Wrzesińskich.

73. OBRAZ rodziny i szkoły w ujęciu interdyscyplinarnym. Pod red. Olgi Zameckiej-Zalas, Izabeli Kiełtyk-Zabrowskiej. Piotrków Trybunalski 2016 Nauk. Wydaw. Piotrkowskie przy Filii UJK ss. 450, nlb. 1, il. UJK. Filia w Piotrkowie Trybunalskim.

Z treści: Bojko Pelagia: Nauczycielska rola dziecka w ujęciu pisarzy dziewiętnastowiecznych. Szkic s. 185-195; Bojko P.: Dzieci nieedukowane (?) - wychowanie przez kulturę w pierwszej połowie XIX wieku s. 197-208; Kiełtyk-Zaborowska Izabela: O dziecku i nie tylko - na marginesie powieści wspomnieniowej Marii Dąbrowskiej „Uśmiech dzieciństwa” s. 209-219; Majchrzyk-Mikuła Joanna, Kisiel Katarzyna: Stan higieniczno-sanitarny szkół powiatu kieleckiego w latach 20. II Rzeczypospolitej s. 221-243; Szymczyk Katarzyna: Sytuacja dziecka sierocego w Piotrkowie Trybunalskim w okresie międzywojennym s. 243-268; Sztanke Grażyna: Kultywowanie tradycji rodzinnych w świetle polskiego czasopiśmiennictwa pedagogicznego s. 269-279; Zamecka-Zalas Olga: Współpraca rodziny i szkoły w zakresie wychowania ojczystego dziecka w szkołach sobotnich w Wielkiej Brytanii s. 281-293. 
74. ORDYŁOWSKI Marek, Szymański Leonard: Problemy higieniczno-zdrowotne i edukacja fizyczna w polskiej myśli medycznej i pedagogicznej oraz praktyce oświatowej od średniowiecza po I wojnę światową. Wrocław-Trzebnica 2016 Dolnośląska Szkoła Wyższa; „,RKa-Print” Roman Kolasa ss. 333 , il.

75. PIETKIEWICZ Iwona, Komorowski Antoni F., Nowakowski Krzysztof: Szkolnictwo i uczelnie polskiej Marynarki Wojennej w latach 1922-2014. Cz. 1. Kwartalnik Bellona. [R. 10]: 2016 nr 1 s. $134-141$.

Toż. Cz. 2. Tamże. [R. 10]: 2016 nr 2 s. 108-118.

76. POLSKIE dziedzictwo pedagogiczne. Rozważania o ideach i instytucjach. Pod red. Joanny Falkowskiej. Toruń 2016 Wydaw. Nauk. UMK ss. 171. (Pedagogika Toruńska; t. 7).

Treść: Falkowska J.: Przedmowa s. 7-12; Ryś Jan: Rola tradycji w wychowaniu żołnierskim XVI-XVII wieku s. 13-27; Opiela Maria: Edukacja dla podtrzymania tradycji i ochrony dziedzictwa kulturowego w pismach Edmunda Bojanowskiego [1814-1871] s. 29-45; Skrzypek Agnieszka: Pamięć o dziedzictwie pierwszych pokoleń służebniczek źródłem kształtowania tożsamości Zgromadzenia Służebniczek Dębickich s. 47-57; Wałęga Agnieszka: Dziedzictwo polskiej teorii i praktyki pedagogicznej na kartach „Szkoły” s. 59-75; Jamrożek Wiesław: Dziedzictwo kulturowe Polaków kresowych - współczesne konteksty edukacyjne (wprowadzenie do problemu) s. 77-94; Chmielewski Witold: Kwestia podtrzymania tradycji i dziedzictwa kulturowego w założeniach edukacyjnych uchodźstwa w czasie drugiej wojny światowej s. 95-110; Jaworska Kazimiera: Piastowie śląscy w pamięci uczniów i nauczycieli pierwszego powojennego Liceum Ogólnokształcącego w Legnicy (1945-1960) s. 111-123; Radziszewska Maria: Szkolne izby pamięci narodowej na Warmii i Mazurach. Ciągłość i zmiana s. 125-139; Bołdyrew Aneta: Pamięć o dziejach „małej ojczyzny”. Edukacyjne i wychowawcze walory historii regionalnej i lokalnej s. 141-155; Śpica Paweł: Pamięć rodzinna a kształtowanie własnej tożsamości - doświadczenie autobiograficzne s. 157-171.

77. PROBLEMY i sukcesy polskiej rodziny w przeszłości i teraźniejszości. Studia historyczno -społeczne. Pod red. Jarosława Durki. Kalisz 2013 Kaliskie Tow. Przyj. Nauk ss. 182, il.

Z treści: Durka J.: Wstęp s. 5-6; Studnicka-Mariańczyk Karolina: Życie codzienne ziemiaństwa na przykładzie rodziny Ostrowskich z Maluszyna s. 8-28; Ziółek Sebastian: Pomoc rodzinom żołnierskim w czasie powstania listopadowego s. 29-37; Białokur Marek: Zabrakło szczęścia. Historia rodzinna pierwszego prezydenta Rzeczypospolitej Gabriela Narutowicza s. 38-63; Werra Jarosław: Rodzina w czasie działań wojennych 1939-1945 s. 64-85; Durka J.: „Młode pokolenie [...] pragnie aby rodzina polska była chrześcijańska” - problematyka wychowania młodzieży w dokumentach Służby Bezpieczeństwa, dotyczących pielgrzymek na Jasną Górę w 1977 roku s. 86-102.

Rec.: Radziszewska Maria, Zeszyty Kaliskiego Towarzystwa Przyjaciót Nauk. Nr 16: 2016 s. 216-218.

78. PUSZKA Alicja: Wpływ systemu wychowawczego św. Jana Bosko na działalność opiekuńczo-wychowawczą zgromadzeń zakonnych w Polsce. Lubelski Rocznik Pedagogiczny. Vol. 35: 2016 no 4 s. $11-29$.

Od końca XIX w.

79. RADZISZEWSKA Maria: Sprawozdanie z I Ogólnopolskiej Konferencji Naukowej „Życie codzienne nauczycieli w XIX i XX wieku. Związki i organizacje nauczycielskie”, Kalisz, 18-19 kwietnia 2016 roku. Przegląd Historyczno-Oświatowy. R. 59: 2016 nr 3/4 s. 302-309.

80. REFLEKSJE i wspomnienia zebrane z okazji 230-lecia szkolnictwa w Pogwizdowie. Nauczanie, wychowanie, rozwój. Red. Ewa Cieńciała. Cieszyn 2016 Oficyna Drukarstwo-Wydawnicza Akant ss. 103, nlb. 1, il.

81. ROLA nauczyciela w wychowaniu. Wczoraj, dziś, jutro. Red. nauk. Barbara Dagmara Niziołek. Tarnów-Łapczyca 2016 Samorządowe Centrum Edukacji; Regis Anita Własnowolska-Bielak ss. 189 , il.

Z treści: Niziołek B. D.: Wprowadzenie s. 4-7; Gretkowski Andrzej: Edukacja i aktywizacja środowiska wiejskiego w ramach działalności Katolickiego Uniwersytetu Ludowego w Proboszczewicach (1938-39) 
s. 26-36; Jaworski Piotr, Kamieński Krzysztof: Wychowawcza i edukacyjna rola Korpusu Ochrony Pogranicza s. 38-55; Juśko Edmund: Nauczyciele galicyjscy w armii austriackiej i Legionach Polskich s. 56-59; Kapuścińska Monika: Ideologiczne uwarunkowania pracy wychowawczej nauczycieli w Polsce w latach 1945-1989 s. 70-81; Niedojadło Andrzej: Uroczystości państwowe ważnym i praktycznym komponentem w realizacji podstawowych założeń i teleologii wychowania państwowego w szkołach powszechnych Okręgu Szkolnego Krakowskiego w II Rzeczypospolitej (1926-1939). Wybrane zagadnienia s. 94-116; Nizołek B. D.: Higiena i zdrowie w pracy wychowawczej szkół galicyjskich w czasie I wojny światowej s. 118-133; Sigda Karolina: Tajne nauczanie w szkołach powszechnych w pierwszych latach II wojny światowej s. 170-182.

82. STAWIAK-OSOSIŃSKA Małgorzata: Początki kształcenia akuszerek w Krakowie (1780-1805). Studia Paedagogica Ignatiana. Vol. 19: 2016 [nr] 3 s. 35-54.

83. SZYBIAK Irena: Szkoła, nauczyciel, wychowanie. Wybór studiów z okazji jubileuszu 75. urodzin i wieloletniej pracy naukowej. Red. nauk. Janina Kamińska, Adam Fijałkowski. Warszawa 2016 Wydawnictwa Uniw. Warszawskiego ss. 592, tabl. 8, il. Wydz. Pedagog. Uniw. Warszawskiego; Tow. Historii Edukacji.

XVIII-XXI w.

84. SZYSZKA Bogdan: Związki kulturalno-oświatowe Lwowa i Zamościa. Zamojskie Studia i Materiaty. Ser. Pedagogika. T. 18: 2016 z. 1 s. 263-275.

Lata 1901-2016.

85. WIĘCEK Katarzyna Małgorzata: Status prawny nauczycieli w szkołach prowadzonych przez osoby prawne Kościoła katolickiego. Katowice 2016 Księg. św. Jacka ss. 264.

Lata 1918-2016.

86. Z BADAŃ nad tradycją polskiej pedagogiki. T. 2: Księga jubileuszowa dedykowana profesor Danucie Koźmian. Red. nauk. Elżbieta Magiera i Joanna Król. Szczecin 2016 Wydaw. Nauk. Wydz. Humanist. US „Minerwa” ss. 727, il. Uniw. Szczeciński.

Toż. Wyd. 2 uzup. Szczecin 2016 ss. 739, il.

Treść: Król J., Magiera E.: Słowo wstępne s. 15-16; Król J., Magiera E.: Słowo wstępne do wydania drugiego s. 17-18; Włodarczyk Edward: Historyk wśród pedagogów. Pedagog wśród historyków s. 19-20; Kromolicka Barbara: Jubileusz Pani Profesor Danuty Koźmian [ur. 1936] s. 21-23; Żółkowska Teresa: Z okazji Jubileuszu Profesor Danuty Koźmian s. 25-26; Jankowski Robert: Jubileusz 80. urodzin Profesor Danuty Koźmian s. 27-39; Jankowski R., Kość Ilona, Magiera E.: Dorobek naukowy prof. zw. dr hab. Danuty Koźmian s. 41-56; Cz. 1. Metodologiczny i formacyjny charakter historii wychowania jako dyscypliny pedagogicznej: Jakubiak Krzysztof: Znaczenie historii wychowania dla pedagogiki kształcenia pedagogicznego w Polsce. Tradycje i aktualne postulaty s. 59-65; Dormus Katarzyna: Historia wychowania w poglądach Stanisława Łempickiego s. 67-77; Gumuła Teresa: Wybrane kierunki badań historyczno-oświatowych w minionym dwudziestoleciu (bez ingerencji cenzury) s. 79-85; Cz. 2. Konteksty społeczno-edukacyjne na przestrzeni dziejów: Ratajczak Krzysztof: Jerozolima ziemska czy niebieska? Co uczestnicy pierwszej krucjaty wiedzieli o celu swej podróży? (Uwagi na marginesie stanu wiedzy geograficznej Europejczyków w XI wieku) s. 89-100; Magiera E.: Początki ruchu spółdzielczego w Europie Zachodniej oraz jego rozwój w XIX i u progu XX wieku s. 101-110; Haratyk Anna: Pozycja społeczna kobiet na Huculszczyźnie w XIX i XX wieku s. 111-120; Bołdyrew Aneta: Formy doraźnej pomocy i wsparcia społecznego w działaniach dobroczynnych w Królestwie Polskim w drugiej połowie XIX i na początku XX wieku s, 121-135; Walak Bogumiła: Historia polskiej książki ilustrowanej dla dzieci i młodzieży w XIX i XX wieku na tle europejskiego dorobku ilustracji książkowej s. 137-151; Głowacka-Sobiech Edyta: Wychowanie i działalność społeczno-edukacyjna kobiet w rodzinach ziemiańskich na przykładzie rodu Zachertów s. 153-160; Woźniak Robert B.: Mikrokręgi społeczne Polaków na pograniczu niemieckim. Ciągłość i zmiana s. 161-173; Orłowska Beata: Pedagogika wobec potrzeb dzieci pochodzących z mniejszości narodowych i etnicznych s. 175-187; Chęcińska Urszula: Miłosz pajdocentryczny s. 189-197; Kość I.: Historie z dzieciństwa uwięzione we wspomnieniach seniorów s. 199-213; Cz. 3. Instytucje społeczno-oświatowe w wymiarze historyczno-pedagogicznym do 1939 roku: Dybiec Julian: Historia wychowania w pracach Towarzystwa Naukowego Krakowskiego (1815-1872) s. 215-226; Michalski Grzegorz: Okoliczności powstania pierwszych na Ziemi Obiecanej gimnazjów rządowych w świetle doniesień „Dziennika Łódzkie- 
go" z lat 1884-1892 s. 227-237; Żołądż-Strzelczyk Dorota: Szkoły i warsztaty zabawkarskie na ziemiach polskich u schyłku XIX i na początku XX wieku s. 239-247; Rędziński Kazimierz: Szkolnictwo żydowskie w Europie Środkowo-Wschodniej w XIX i na początku XX wieku (ze szczególnym uwzględnieniem Galicji) s. 249-257; Maliszewski Tomasz: Problematyka oświatowa na łamach włościańskiego pisma „Siewba” (1906-1908) s. 259-269; Michalska Iwonna: Wspieranie funkcjonowania bibliotek dla dzieci i młodzieży w dwudziestoleciu międzywojennym s. 271-282; Apanel Danuta: Szkolnictwo powszechne w powiecie wrzesińskim w latach 1918-1939 s. 283-295; Cz. 4. Instytucje społeczno-oświatowe w wymiarze historyczno-pedagogicznym w drugiej połowie XX i na początku XXI wieku: Chmielewski Witold: Szkoła „oficerów oświatowych”. Państwowy kurs pedagogiczno-oświatowy w Łodzi w latach 1948-1952 s. 299-325; Wilczyński Zenon: Odbudowa i rozwój szkolnictwa w województwie pomorskim w latach 1945-1948 s. 327-341; Radziszewska Maria: Powstanie i działalność pierwszego uniwersytetu ludowego w Okręgu Mazurskim pod kuratelą Instytutu Mazurskiego w Olsztynie s. 343-358; Więckowski Paweł: Kaganek oświaty na „Dzikim Zachodzie”. Rola szkolnictwa w procesie integracji społeczeństwa na Pomorzu Zachodnim po 1945 roku s. 359-369; Horyń Lidia: Warunki lokalowe i materialne placówek wychowania przedszkolnego w województwie szczecińskim po drugiej wojnie światowej s. 371-384; Wiażewicz-Wójtowicz Paula: Podstawowe szkoły muzyczne Szczecina na przełomie XX i XXI wieku s. 403-413; Cz. 5: Różne wymiary teorii i praktyki edukacyjnej: Łapot Mirosław: Warunki sanitarno-higieniczne szkolnictwa ludowego w dobie autonomii galicyjskiej na przykładzie szkół żydowskich we Lwowie s. 417-430; Nawrot-Borowska Monika: Obrazki z dziejów lalki s. 431-455; Walasek Stefania: Nauka rysunku w teorii i praktyce szkolnej II Rzeczypospolitej. Wybrane problemy s. 457-467; Sapia-Drewniak Eleonora: Nauka języka polskiego w pracy edukacyjnej na Śląsku Opolskim w okresie międzywojennym s. 469-476; Wolter Edyta: Edukacja ekologiczna w II Rzeczypospolitej inspiracją dla praktyki edukacyjnej w XXI wieku s. 477-490; Gołdyn Piotr: „Kościelczanka” - gazeta wychowanek Szkoły Gospodarczej w Kościelcu s. 491-502; Kabzińska Łucja: Nurt psychologiczny w badaniach pedagogicznych nad dzieckiem w II Rzeczypospolitej s. 503-517; Gulczyńska Justyna: Postawy licealisty wobec szkoły w okresie PRL-u zarys problematyki s. 519-528; Grzybowski Romuald: Przygotowanie uczniów do odbioru przekazu propagandy komunistycznej jako element ukrytego programu realizowanego w szkołach z lat PRL-u (na przykładzie wychowania obywatelskiego) s. 529-543; Król Joanna: Model normatywny członka Związku Młodzieży Polskiej (1948-1957) i jego weryfikacja w rzeczywistości szkolnej średnich szkół ogólnokształcących s. 545-554; Cz. 6. Twórcy myśli pedagogicznej i działacze oświatowi: Kamińska Janina: Roman Symonowicz - wychowanek Szkoły Głównej Wielkiego Księstwa Litewskiego s. 557-570; Andrukowicz Wiesław: Człowiek dobry istotnie. W 80. rocznicę urodzin Profesor Danuty Koźmian s. 571-580; Sztobryn Sławomir: Zygmunta Mysłakowskiego ocena stanu pedagogiki u progu II Rzeczypospolitej s. 581-589; Wenta Kazimierz: W dyskusji nad książką Profesor Danuty Koźmian pt. „Janusz Jędrzejewicz - polityk i pedagog (1889-1951)” s. 605-617; Wlazło Marcin: Współczesna pedagogika specjalna wobec dziedzictwa Marii Grzegorzewskiej s. 619-626; Cz. 7. Wokół zawodu nauczyciela: Dziaczkowska Lucyna: Autorytet nauczyciela jako źródło rozwoju ucznia s. 629-649; Topij-Stemplińska Beata: W poszukiwaniu nauczyciela doskonałego. Biografie pedagogiczne nauczycieli XX wieku s. 651-660; Gorloff Elżbieta: Kształcenie nauczycieli edukacji wczesnoszkolnej w PRL-u w latach 60. I 70. XX wieku - koncepcje zmian i ich realizacja s. 661-672; Materne Agnieszka: Niekompetentny pedagog czy pseudoartysta? Najczęstsze błędy w edukacji plastycznej s. 673-683; Cz. 8. Z praktyki resocjalizacyjnej: Kołakowski Andrzej: Landeserzehungsastallt 0/8 w Grodkowie jako egzemplifikacja systemu resocjalizacji nieletnich w III Rzeszy s. 685-700; Jarzębińska Aneta, Bytniewski-Judasz Mateusz: Uwarunkowania i przykłady działalności resocjalizacyjnej w środowisku Aresztu Śledczego w Szczecinie s. 701-711; Popek Paweł: Paradygmaty pracy pedagogicznej a funkcjonowanie nieletnich w placówkach resocjalizacyjnych s. 713-724.

87. ZALAS Katarzyna: Działalność Sekcji Wsparć Niezamożnej Młodzieży Szkolnej w Częstochowie w latach 1916-1925. Zarys problematyki. Prace Naukowe Akademii im. Jana Długosza. Pedagogika. T. 24: 2015 s. 617-626.

88. ZBYRAD Teresa: W trosce o dziecko - kształtowanie się form opieki od średniowiecznych szpitali do domów pomocy społecznej. Polska Myśl Pedagogiczna. Nr 2: 2016 s. 391-409.

Do współczesności.

89. ŻYMIERSKI Mariusz: Dzieje szkolnictwa gminy Woźniki. Woźniki 2016 OSP ss. 110, il. 


\section{Okres do 1795 roku}

90. BIEŚ Andrzej Paweł: Periodyzacja obecności Towarzystwa Jezusowego na ziemiach polskich. Struktury organizacyjne oraz edukacyjno-oświatowe i pastoralne formy aktywności. Cz. 1. Studia Paedagogica Ignatiana. Vol. 17: 2014 s. 57-87.

XVI-XVIII w.

91. CZERNIECKA-HABERKO Anna: Oddziaływanie wychowawcze na wychowanka czyli wychowanie ostatniego Jagiellona w ujęciu Józefa Skoczka. Prace Naukowe Akademii im. Jana Dlugosza. Zeszyty Historyczne. T. 15: 2016 s. 57-70.

92. CZERNIECKA-HABERKO A.: Upbringing and education of the last Jagiellonian king inthe perspektive of Antoni Danysz. Prace Naukowe Akademii im. Jana Dlugosza. Pedagogika. T. 25: 2015 nr 2 s. 411-422.

A. Danysz „O wychowaniu Zygmunta Augusta”, Kraków 1915.

93. DOKUMENT pergaminowy - ,świadectwo ukończenia nauki w zawodzie leśnego i polnego myśliwego" ze zbiorów Muzeum w Gliwicach. [Wyd.] Anna Kulczyk. Rocznik Muzeum w Gliwicach. T. 26: 2016 s. 283-289.

Z 7 IX $1761 \mathrm{r}$.

94. DORMUS Katarzyna: Dziecko w czasach Komisji Edukacji Narodowej. Rocznik Komisji Nauk Pedagogicznych. R. 68: 2015 s. 129-142.

95. DURBAS Małgorzata: Szkoła kadetów w Lunéville w latach 1737-1766. Polscy wychowankowie. Prace Naukowe Akademii im. Jana Dlugosza. Pedagogika. T. 24: 2015 s. 429-443.

96. DURBAS M.: Szkoła Kadetów w Lunéville króla Stanisława Leszczyńskiego w świetle regulaminów. Rozprawy z Dziejów Oświaty. T. 53: 2016 s. 27-43.

97. DZIECIŃSTWO i starość w ujęciu historyków. Red. Anna Obara-Pawłowska, Małgorzata Kołacz-Chmiel. Lublin 2016 Wydaw. UMCS ss. 312, il.

Z treści: Łozowski Piotr: Sytuacja sierot i starców w mieście późnośredniowiecznym na ziemiach polskich. Przegląd badań s. 49-63; Konarska-Zimnicka Sylwia: „Przyszłość dziecka zapisana w gwiazdach” - czyli krakowskie horoskopy urodzeniowe do 1550 roku. Stan badań s. 65-81; Pielas Jacek: Opieka nad nieletnimi w rodzinach szlacheckich w Koronie do końca XVIII wieku w świetle polskiej historiografii s. 83-95; Bubczyk Robert: Gry i zabawy okresu dzieciństwa jako składnik edukacji arystokracji feudalnej w średniowiecznej Europie s. 153-166; Teterycz-Puzio Agnieszka: Niebezpieczne dzieciństwo i sędziwa starość - refleksje średniowiecznych kronikarzy i hagiografów o początku i schyłku życia s. 167-188; Kołacz-Chmiel Małgorzata: Nieletni pochodzenia chłopskiego w praktyce sądów kościelnych w późnośredniowiecznej Małopolsce s. 207-226; Żołądź-Strzelczyk Dorota: Dzieciństwo w epoce staropolskiej - możliwości źródłowe i kierunki badań s. 227-242; Justyniarska-Chojak Katarzyna: Dziecko w rodzinie mieszczańskiej w XVI-XVIII wieku w świetle przepisów prawa magdeburskiego (pomiędzy normą a praktyką) s. 243-266.

98. GAD Paweł: „Ojcowskim sercem i słowem”. Instrukcja wychowawcza autorstwa Hieronima Floriana Radziwiłła [1715-1760]. Ogrody Nauk i Sztuk. T. 6: 2016 s. 215-226.

99. HAŠKOVÁ Veronika, Zubal Pavol: Polnische Studenten am Kollegium der Piaristen in Podolinec auf dem Slowakischen Gebiet im 17.-18. Jahrhundert. Roczniki Pedagogiczne. T. 8: 2016 nr 2 s. 109-120.

100. JABŁOŃSKA Anna: Nauczyciel szkoły parafialnej w siedemnastowiecznej Rzeczypospolitej na przykładzie archidiakonatu gnieźnieńskiego - założenia a rzeczywistość. Przeglad Historyczno-Oświatowy. R. 59: 2016 nr 1/2 s. 7-25. 
101. JABŁOŃSKA A.: Obraz szkolnictwa parafialnego archidiakonatu gnieźnieńskiego z końca XVII wieku w świetle wizytacji Stanisława Lipskiego. Przeglad Historyczno-Oświatowy. R. 59: $2016 \mathrm{nr} 3 / 4$ s. $7-26$.

102. KAMIŃSKA Janina, Kula Ewa: Źródła do dziejów Komisji Edukacji Narodowej w zasobach Rosyjskiego Państwowego Archiwum Akt Dawnych w Moskwie. Rozprawy z Dziejów Oświaty. T. 53: 2016 s. $135-147$.

103. KULA Ewa: Nauczyciele i uczniowie szkoły podwydziałowej w Kamieńcu Podolskim w czasach Komisji Edukacji Narodowej. Prace Naukowe Akademii im. Jana Dtugosza. Pedagogika. T. 25: $2015 \mathrm{nr} 2$ s. 347-360.

104. KULA E.: Organizacja i funkcjonowanie szkoły podwydziałowej w Kamieńcu Podolskim w czasach Komisji Edukacji Narodowej. Prace Naukowe Akademii im. Jana Dlugosza. Pedagogika. T. 25: $2015 \mathrm{nr} 1$ s. 621-633.

Lata $1781-1793$.

105. MROZIUK Tadeusz: Poglądy Hugona Kołłątaja na oświatę przed rozpoczęciem przez niego działalności związanej z pracami Sejmu Czteroletniego w świetle publicystyki epoki. Ogrody Nauk i Sztuk. T. 6: 2016 s. 39-50.

106. [POSOHOVA Lûdmila ] Posochowa Ludmiła: „Narodziny” szlachcica. Ideały i praktyka wychowawcza dzieci starszyzny kozackiej na Hetmańszczyźnie i Ukrainie Słobodzkiej w drugiej połowie XVIII wieku. Zeszyty Naukowe Uniwersytetu Jagiellońskiego. Prace Historyczne. [T.] 143: 2016 z. 2 s. $361-369$.

107. SROGOSZ Tadeusz, Wołyniec Iwona: Oświata ludowa jako czynnik poprawy stanu zdrowia ludności według populacjonistów polskich w XVIII wieku. Prace Naukowe Akademii im. Jana Dlugosza. Pedagogika. T. 25: 2015 nr 2 s. 325-246.

108. TARASZKIEWICZ Jacek: Pierwsze stulecie zakonu pijarów na ziemiach Rzeczypospolitej Obojga Narodów (1642-1740). Gdańsk 2015 Wydaw. Uniw. Gdańskiego ss. 362.

Rec.: Kostkiewicz Janina, Polska Myśl Pedagogiczna. Nr 2: 2016 s. 455-460.

109. TARASZKIEWICZ J.: Wychowanie religijne elementem edukacji pijarskiej w Rzeczypospolitej Obojga Narodów na przełomie XVII i XVIII wieku. Colloquium. 2016 nr 1 s. 101-116.

110. WIŚNIEWSKA Halina: Nazwy dzieci i młodzieży w słowniku Grzegorza Knapiusza (1643). [W:] Dziecko. Literatura, sztuka, język. Pod red. Romana Starza. Kielce 2016 s. 445-456.

111. WÓJCIK Jacek: Relacja Thomasa Plattera jako źródło do życia codziennego uczniów wrocławskich szkół na początku XVI wieku. Biuletyn Historii Wychowania. [Nr] 34: 2016 s. 7-19.

\section{Okres 1795-1918}

112. BANAŚ-BARAN Ewa: Wychowanie moralne i religijne ubogich i sierot w Krakowskim Towarzystwie Dobroczynności w latach 1816-1918. Studia Paedagogica Ignatiana. Vol. 19: 2016 [nr] 2 s. $65-88$.

113. BARNAŚ-BARAN E.: Nauczyciele sierot w Krakowskim Towarzystwie Dobroczynności w latach 1817-1912. Lubelski Rocznik Pedagogiczny. Vol. 35: 2016 no 4 s. 31-48. 
114. BARNAŚ-BARAN E.: Świętowanie w wiejskiej rodzinie galicyjskiej. Studia i Prace Pedagogiczne. Nr 1: 2014 s. 273-288.

115. BEDNARCZUK Monika: Wielojęzyczność w kontekście akademickim. Sieci naukowe, samokształcenie i polityka w Wilnie (w końcu XVIII i pierwszych dekadach XIX wieku). Wielogłos. 2016 nr 2 s. $27-62$.

116. BEDNARZ-GRZYBEK Renata: Kształtowanie charakteru dzieci i młodzieży na ziemiach polskich w drugiej połowie XIX i na początku XX wieku. Studia Edukacyjne. Nr 31: 2014 s. $267-287$.

117. BIEŚ Andrzej Paweł, Królikowska Anna, Topij-Stempińska Beata: Konferencja naukowa „Instytucje edukacyjne w Krakowie i na ziemiach polskich w XIX wieku i początkach XX wieku”, Kraków, 1-2 kwietnia 2016 roku. Przegląd Historyczno-Oświatowy. R. 59: 2016 nr 1/2 s. 239-247.

118. BOŁDYREW Aneta: Źródła do badań nad ochronkami jako instytucjami opiekuńczo-wychowawczymi w Królestwie Polskim w XIX i na początku XX wieku. Studia Paedagogica Ignatiana. Vol. 19: 2016 [nr] 2 s. 271-289.

119. BUCZEK Katarzyna: Karola Kaczkowskiego publiczne lekcje higieny w Liceum Wołyńskim. Rozprawy z Dziejów Oświaty. T. 53: 2016 s. 11-27.

120. DOBKOWSKA Joanna: Poglądy w kwestii potrzeby oraz zakresu edukacji kobiet panujące w drugiej połowie XIX i na przełomie XIX i XX wieku. Acta Univeristatis Lodziensis. Folia Historica. [Vol.] 96: Studia i szkice do dziejów Polski i powszechnych od XVI do XX w.: 2016 s. 89-107.

121. DOLATA Elżbieta: Galicyjscy popularyzatorzy zdrowia i higieny przełomu XIX i XX wieku. Lubelski Rocznik Pedagogiczny. Vol. 35: 2016 no 4 s. 79-95.

122. DOLATA E.: Obraz dzieciństwa galicyjskiego z przełomu XIX i XX wieku. Kwartalnik Edukacyjny. $2016 \mathrm{nr} 3$ s. 14-28.

123. DOLATA E.: „Rodzina i Szkoła” wobec zagrożeń dzieciństwa na przełomie XIX i XX wieku. [W:] Dzieciństwo i starość w ujęciu historyków. Red. Anna Obara-Pawłowska, Małgorzata Kołacz-Chmiel. Lublin 2016 s. 267-278.

124. DORMUS Katarzyna: Krakowskie gimnazjum żeńskie przełomu XIX i XX wieku. Studia Paedagogica Ignatiana. Vol. 19: 2016 [nr] 2 s. 87-103.

125. DZIKI Tomasz: Z dziejów oświaty wsi Kujaw wschodnich w pierwszej połowie XIX wieku. Zapiski Kujawsko-Dobrzyńskie. T. 31: 2016 s. 81-100.

126. FASZCZA Łukasz: Szkolnictwo na terenie guberni wileńskiej w okresie I wojny światowej. Perspektywa widziana oczami polskiej społeczności. Biuletyn Historii Pogranicza. Nr 15: 2015 s. 13-35.

127. GALEK Czesław: Kary w szkołach galicyjskich przełomu XIX i XX wieku. Studia i Prace Pedagogiczne. Nr 1: 2014 s. 303-312.

128. GALEK Cz.: Postawy patriotyczne uczniów zaboru pruskiego przełomu XIX i XX wieku w świetle literatury pamiętnikarskiej i beletrystycznej. Przegląd Historyczno-Oświatowy. R. 59: $2016 \mathrm{nr} 3 / 4$ s. $73-86$. 
129. GALEK Cz.: Szkolnictwo w zaborze pruskim na przełomie XIX i XX wieku w świetle literatury pamiętnikarskiej i beletrystycznej. Przegląd Historyczno-Oświatowy. R. 59: 2016 nr 1/2 s. $40-62$.

130. GALEK Cz.: Szkoła polska drugiej połowy XIX wieku w zaborze pruskim w świetle pamiętników i literatury pięknej. Zamość 2016 Wyższa Szkoła Zarządzania i Administracji ss. 270.

131. GARCZYK Bartłomiej: Petersburg jako ośrodek akademicki przełomu XIX i XX wieku. Studia Ekonomiczne. Zarządzanie. 2016 nr 6 s. 115-134.

Również o Polakach.

132. GLUGLA Paweł: Szkolnictwo zawodowe w Galicji na początku XX wieku. Nowa Szkoła. R. 72[73]: $2016 \mathrm{nr} 4$ s. $42-52$.

133. GŁOWACKI Marian: Walka o szkołę polską w latach 1906-1914 w Częstochowie i późniejsza aktywność jej uczestników. Ziemia Częstochowska. [T.] 42: 2016 s. 11-27.

134. GÓRSKA Urszula: Drogi wolności. Ruch emancypacyjny kobiet w monarchii habsburskiej na podstawie publicystyki i twórczości literackiej w latach 1867-1918. Warszawa 2016 IBL PAN. Wydaw. ss. 271.

M.in. działalność edukacyjna.

135. GRABOWSKA-PIEŃKOSZ Dorota: Zapisani w pamięci. Nauczyciele zaboru austriackiego w literaturze pamiętnikarskiej. Toruń 2016 Wydaw. Nauk. UMK ss. 382, il. (Pedagogika Toruńska; t. 10).

136. GRZEBIEŃ Ludwik: Początki instytucjonalnej „Opieki” nad młodzieżą przemysłową i rękodzielniczą w Krakowie na przełomie XIX i XX wieku. Studia Paedagogica Ignatiana. Vol. 19: 2016 [nr] 3 s. 163-180.

Opieka św. Stanisława Kostki nad Młodzieżą Terminatorską w Krakowie.

137. HARBIG Anna Maria: Die aufgezwungene Sprache. Deutsch in galizischen Schulen (1772-1848). Białystok 2016 Wydaw. Uniw. w Białymstoku ss. 416.

138. IWAŃSKA Marzena: Nauczycielskie integracje i dezintegracje w Łodzi przed I wojną światową. Rocznik Łódzki. T. 64: 2016 s. 101-123.

139. JAKUBIAK Krzysztof, Nawrot-Borowska Monika: Rodzina polska w XIX wieku jako środowisko wychowawcze i jej funkcja edukacyjna. Studia Paedagogica Ignatiana. Vol. 19: 2016 [nr] 2 s. 15-47.

140. JASIŃSKI Paweł: Życie oświatowe na podstawie „Głosu Płockiego” wydawanego w latach 1908-1914. Notatki Płockie. 2016 [nr] 3 s. 36-46.

141. JĘDRYCHOWSKI Zbigniew: [Juliusz] Słowacki na uniwersytecie. Pamiętnik Teatralny. R. 65: 2016 z. 1/2 s. 114-138.

W Wilnie w 1. 1824-1828.

142. JURKOWSKI Roman: Wileńskie instytucje i towarzystwa dobroczynne w latach 1905-1907 w świetle doniesień „Kuriera Litewskiego” i „Dziennika Wileńskiego”. Cz. 1. Przegląd Wschodnioeuropejski. [T.] 7: 2016 [nr] 1 s. 29-44.

143. JUŚKO Edmund: Szkolnictwo polskie na terenie Galicji w dobie Wielkiej Wojny. Wyd. 2. uzup. i rozsz. Tarnów-Łapczyca-Stalowa Wola 2016 Katedra Pedagogiki Szkolnej i Zarządzania 
Oświatą. Inst. Pedagogiki WZPiNOS KIL JP II; Regins Anita Własnowolska-Bielak ss. 317, nlb. 1 , il.

Wyd. 1 pt.: Z dziejów polskiego szkolnictwa na terenie Galicji w dobie wielkiej wojny. Tarnów-Stalowa Wola 2015.

144. KABACIŃSKA- $€ U C Z A K$ Katarzyna: Relacje rodzinne na łamach wybranej codziennej prasy wielkopolskiej w II połowie XIX wieku. Studia Edukacyjne. Nr 35: 2015 s. 297-325.

145. KALINOWSKA-WITEK Barbara: Rola lalki w socjalizacji i wychowaniu dziewcząt w XIX wieku. Kwartalnik Edukacyjny. 2016 nr 3 s. 3-13.

146. KALINOWSKA-WITEK B.: Wkład Elizy Orzeszkowej w propagowanie kwestii kobiecej oraz kształtowania dążeń edukacyjnych młodych Polek w II połowie XIX wieku. Lubelski Rocznik Pedagogiczny. Vol. 35: 2016 no 4 s. 49-63.

147. KNOP Marcelina: Wychowanie dziewcząt w działalności i poglądach bł. Marceliny Darowskiej [1827-1911]. Biuletyn Historii Wychowania. [Nr] 34: 2016 s. 101-115.

148. KSIĄŻEK Magdalena: Dzieje dobroczynności w Kielcach w XIX i początkach XX wieku. Kielce 2016 Muzeum Historii Kielc ss. 284, il.

Do 1914 r.

149. KULA Ewa: Język wykładowy w szkołach zaboru rosyjskiego jako przedmiot obrad Komitetu do Spraw Królestwa Polskiego. Przegląd Historyczno-Oświatowy. R. 59: 2016 nr 1/2 s. $159-172$.

W 1869 r.; aneks źródłowy.

150. KULA E.: Nauczyciele języka polskiego w szkołach średnich Królestwa Polskiego na tle polityki oświatowej w okresie przejściowym (1864-1873). Prace Naukowe Akademii im. Jana Dlugosza. Pedagogika. T. 24: 2015 s. 445-457.

151. LEŻAŃSKA Wiesława: Wizerunek nauczyciela wczesnej edukacji w pedagogice Henryka Wernica [1829-1905]. Przegląd Historyczno-Oświatowy. R. 59: 2016 nr 1/2 s. 26-39.

152. LIACHOŬSKI Uladzimir: Niemiecka polityka edukacyjna w okręgu administracyjnym Białystok-Grodno w latach 1915-1918. Komunikaty Mazursko-Warmińskie. [R. 59]: 2015 nr 2 s. $325-337$.

153. ŁAPOT Mirosław: Edukacja dziewcząt żydowskich w Szkole Ludowej im. Abrahama Kohna we Lwowie (1844-1914). Prace Naukowe Akademii im. Jana Dlugosza. Pedagogika. T. 24: 2015 s. 483-504.

154. MADZIAR Dawid: Trudnie ścieżki zawodowe dydaktyków Śląska Cieszyńskiego w XIX i na początku XX wieku. Wieki Stare i Nowe. T. 11: 2016 s. 184-188.

155. MAGIERA Elżbieta: Zarys rozwoju ruchu spółdzielczego na ziemiach polskich pod zaborem pruskim w drugiej połowie XIX i na początku XX wieku oraz jego edukacyjny charakter. Studia Paedagogica Ignatiana. Vol. 19: 2016 [nr] 3 s. 181-200.

156. MARKIEWICZOWA Hanna: Działalność opiekuńcza na ziemiach polskich w XIX wieku na przykładzie Towarzystw Dobroczynności: Wileńskiego i Warszawskiego. Prace Naukowe Akademii im. Jana Dlugosza. Pedagogika. T. 25: 2015 nr 1 s. 635-664.

157. MOLIK Witold: Polscy studenci na uniwersytetach niemieckich od końca XVIII do początku XX wieku. T. 1. Poznań 2016 Wydaw. Nauka i Innowacja ss. 365, nlb. 1. PTH. 
158. MOTOW Irena: Ponadczasowość inicjatyw reformatorskich Fryderyka Skarbka [1792-1866] w resocjalizacji. Prace Naukowe Akademii im. Jana Dlugosza. Pedagogika. T. 25: 2015 nr 1 s. $645-657$.

159. NAWROT-BOROWSKA Monika: „Nikt nam polskości z serca wyrwać nie jest zdolny” - ze wspomnień Leokadii Boniewicz o wychowaniu na wsi chełmińskiej w okresie strajków szkolnych. Rozprawy z Dziejów Oświaty. T. 53: 2016 s. 61-82.

160. NIEPODLEGŁOŚCIOWE koncepcje i programy wychowania przełomu XIX i XX wieku. I Seminarium Polskiej Myśli Pedagogicznej myśl o wychowaniu dla Polski niepodległej 1863-1914/18. Red. nauk. Beata Gola, Dominika Jagielska, Janina Kostkiewicz. Kraków 2015 Poligrafia Salezjańska ss. 197.

Treść: Gola B., Jagielska D., Kostkiewicz J.: Wstęp s. 7-9; Cz. 1. Problemy badań nad polską myślą pedagogiczną: Kostkiewicz J.: O potrzebie badań nad polską myślą pedagogiczną - obszary zaniechane, obszary wymagające reinterpretacji s. 13-27; Palka Stanisław: Uwarunkowania rozwoju polskiej myśli pedagogicznej (uwagi ogólne) s. 29-34; Gola B.: Program nauczania a kontekst jego funkcji społecznych s. 35-51; Cz. 2. Ramy czasowe w myśleniu o „wychowaniu dla niepodległej” na przełomie XIX i XX wieku - dwugłos: Hejnicka-Bezwińska Teresa: Niektóre problemy związane z koncepcją badań nad „Myślą o wychowaniu dla Polski niepodległej (1863-1914/18)" s. 55-65; Kostkiewicz J.: Kwestia ram czasowych tematu I Seminarium Polskiej Myśli Pedagogicznej „Myśl o wychowaniu dla Polski niepodległej (1863-1914/18)”. Uzasadnienie s. 67-73; Cz. 3. Polskie koncepcje i programy wychowania do niepodległości 1863-1914/18: Dziaczkowska Lucyna: Nauczyciel a program kształcenia w świetle refleksji pedeutologicznej Jana Władysława Dawida s. 77-92; Sajdek Wiesława: Program wychowania kobiet wedle wskazówek Eleonory Ziemięckiej s. 93-104; Ryk Andrzej: Pedagogia polska Władysława Seredyńskiego i jej niepodległościowe aspekty s. 105-121; Hajduk Łukasz: Skauting jako program wychowania młodzieży. Andrzej Małkowski i zakorzenienie idei Roberta Baden -Powella na polskim gruncie s. 123-135; Mółka Janusz: Wychowanie młodzieży w Sodalicji Mariańskiej s. 137-147; Michel Małgorzata: Rozwój opieki nad dzieckiem przestępczym pod zaborami. Działalność Towarzystwa Osad Rolnych i Przytułków Rzemieślniczych na rzecz wolności jednostki wykluczonej s. 149-160; Kusztal Justyna: Studzieniec - praktyczna realizacja idei ochrony dziecka zaniedbanego moralnie na ziemiach polskich zaboru rosyjskiego s. 161-172; Dybiec Julian: Idee pedagogiczne w polskiej literaturze 1795-1918 s. 173-187; Załączniki: Komunikat założycielski i programowy Seminarium Polskiej Myśli Pedagogicznej s. 191-193; Program I Seminarium Polskiej Myśli Pedagogicznej s. 194-197.

161. NIEWĘGŁOWSKA Aneta: Średnie szkolnictwo żeńskie w dziewiętnastowiecznym Grudziądzu. Rocznik Grudziądzki. T. 23: 2015 s. 111-127.

162. NOWAK Gabriela: Żydowskie szkolnictwo w Płocku w latach 1865-1914 w świetle źródeł archiwalnych. Rocznik Muzeum Mazowieckiego w Płocku. Nr 20: 2016 s. 182-198.

163. ONISZCZUK Aleksandra: Doświadczenia Księstwa Warszawskiego w zakresie edukacji prawniczej. Krytyka Prawa. T. 8: 2016 s. 67-90.

164. [PAPENKO Evgen] Papenko Yevgen: Participation of the Ukrainian „Sokil” movement in a military-patriotic education of youth before the I World War. Studia Warmińskie. T. 53: 2016 s. $421-430$.

165. PELCZAR Roman: Sieć szkolna w koloniach niemieckich (józefińskich) do 1873 r. (na przykładzie terenu łacińskiej diecezji przemyskiej). Studia i Prace Pedagogiczne. Nr 3: 2016 s. $143-166$.

166. PIEKARSKI Michał: Ks. Wacław Sierakowski - propagator wiedzy o muzyce i organizator szkolnictwa muzycznego w okresie działalności Komisji Edukacji Narodowej. Biuletyn Historii Wychowania. [Nr] 34: 2016 s. 85-99. 
167. PISARSKI Grzegorz: Studenci śląskiego Uniwersytetu im. Fryderyka Wilhelma we Wrocławiu pochodzący z powiatu jeleniogórskiego (bez Jeleniej Góry) w czasie I wojny światowej (1914-1918). Rocznik Jeleniogórski. T. 48: 2016 s. 77-86.

170. PODOLAK-ZAJĄC Jolanta: Galicyjscy przedstawiciele pedagogiki opiekuńczej. Ich działalność i dorobek naukowy. Studia i Prace Pedagogiczne. Nr 1: 2014 s. 289-301.

168. PODOLAK-ZAJĄC J.: Udział galicyjskich lekarzy i higienistów w pracach opiekuńczo-wychowawczych. Studia i Prace Pedagogiczne. Nr 2: 2015 s. 183-196.

169. PODOLAK-ZAJĄC J.: Udział galicyjskich prawników w kształtowaniu się prawnych podstaw opieki nad dziećmi i młodzieżą. Studia i Prace Pedagogiczne. Nr 3: 2016 s. 193-209.

171. POTOCZNY Jerzy: Udział galicyjskich towarzystw oświatowych w popularyzowaniu włościańskiej kultury teatralnej. Studia i Prace Pedagogiczne. Nr 3: 2016 s. 167-181.

172. POTOCZNY J.: Udział Towarzystwa Oświaty Ludowej w krzewieniu czytelnictwa i popularyzacji wiedzy wśród plebejskich warstw społeczeństwa galicyjskiego. Studia i Prace Pedagogiczne. $\mathrm{Nr}$ 1: 2014 s. 261-271.

173. POTOCZNY J.: Wkład towarzystw oświatowo-naukowych Galicji Wschodniej doby autonomicznej w rozwój świadomości i tożsamości narodowej Ukraińców. Studia i Prace Pedagogiczne. Nr 2: 2015 s. 197-212.

174. POZNAŃSKI Karol: Raport ministra Oświecenia Narodowego Awraama Norowa z wizytacji szkół Okręgu Naukowego Warszawskiego w 1856 roku. Przegląd Historyczno-Oświatowy. R. 59: $2016 \mathrm{nr} 3 / 4$ s. 144-179.

175. PUCHOWSKA Małgorzata: Sprawozdanie z konferencji „Instytucje edukacyjne w Krakowie i na ziemiach polskich w XIX i początkach XX wieku". Akademia Ignatianum w Krakowie, 1-2 kwietnia 2016. Biuletyn Historii Wychowania. [Nr] 34: 2016 s. 227-235.

176. RĘDZIŃSKI Kazimierz: Początki szkolnictwa w Sosnowcu (1870-1914). Studia i Prace Pedagogiczne. Nr 1: 2014 s. 313-337.

177. SADURSKI Ireneusz: Działalność pedagogiczna Eugeniusza Stepanowa - profesora języka i literatury rosyjskiej w Gimnazjum Lubelskim w latach 1856-1863. Rocznik Instytutu Europy Środkowo-Wschodniej. R. 14: 2016 z. 1 s. 119-133.

178. SAJDEK Wiesława: Jakiej filozofii pedagodzy potrzebują? O początkach pedagogiki uniwersyteckiej w Krakowie. Polska Myśl Pedagogiczna. Nr 2: 2016 s. 345-358.

Trzy pierwsze dekady XIX w.

179. SAMSEL Agata, Wróblewska Urszula: Uczniowie białostockich szkół w walce z rusyfikacją (1807-1915). Przegląd Historyczno-Oświatowy. R. 59: 2016 nr 3/4 s. 40-56.

180. SAPIA-DREWNIAK Eleonora: Działalność oświatowa towarzystw na Górnym Śląsku na przełomie XIX i XX stulecia. Studia Paedagogica Ignatiana. Vol. 19: 2016 [nr] 2 s. 47-63.

181. [SOKOLOV Aleksandr Rostislavovič] Sokołow Aleksander R.: Dobroczynność w Rosji Carskiej od czasów dawnych do początku XX wieku. Tł. Krystyna Bogucka. Warszawa 2013 Wyższa Szkoła Pedagogiczna Tow. Wiedzy Powszechnej ss. 150, nlb. 1, il.

Rec.: Markiewiczowa Hanna, Przegląd Historyczno-Oświatowy. R. 59: 2016 nr 3/4 s. 277-282. 
182. STANKIEWICZ-KOPEĆ Monika: Poglądy Klementyny z Tańskich Hoffmanowej 1798-1845 w refleksji uczennic. Zarys zagadnienia. Studia Paedagogica Ignatiana. Vol. 19: 2016 [nr] 3 s. 99-121.

183. STUDNICKA-MARIAŃCZYK Karolina: Wzór wielokulturowości w wychowaniu panien i kawalerów z dworów ziemiańskich w Królestwie Polskim. Prace Naukowe Akademii im. Jana Dlugosza. Pedagogika. T. 25: 2015 nr 2 s. 375-389.

184. SZKOLNICTWO, opieka i wychowanie w Królestwie Polskim. Od jego ustanowienia do odzyskania przez Polskę niepodległości 1815-1918. Pod red. Hanny Markiewiczowej i Iwony Czarneckiej. Warszawa 2016 Wydaw. Akad. Pedagogiki Specjalnej ss. 248, il. (Wokół Historii Wychowania).

Treść: Markiewiczowa H.: Wstęp s. 7-9; Poznański Karol: Krótko o działalności oświatowej Pawła Muchanowa w Królestwie Polskim w latach 1842-1861 s. 11-34; Winiarz Adam: Geneza i rozwój polityki oświatowej Królestwa Polskiego doby autonomicznej oraz krótko- i długofalowe rezultaty s. 35-53; Suplicka Agnieszka: Wpływ strajku szkolnego na rozwój szkolnictwa prywatnego s. 54-64; Markiewiczowa H.: Geneza, organizacja i działalność polskiej Macierzy Szkolnej w latach 1905-1907 s. 65-79; Wałęga Agnieszka: „Z zaborów...”. Galicyjska „Szkoła” wobec problemów rozwoju oświaty w Królestwie Polskim (1905-1918) s. 80-89; Michalski Grzegorz: Propagowanie pedagogiki Fryderyka Froebla w warszawskim piśmiennictwie periodycznym drugiej połowy XIX i początków XX wieku s. 90-99; Michalski Jarosław: Wokół myśli o nauczycielu Feliksa Jezierskiego s. 100-110; Falkowska Joanna: Recepcja zachodniej myśli pedagogicznej w twórczości Izabeli Moszczeńskiej (1864-1941) s. 111-122; Bugajska-Więcławska Joanna: „Przyszłym historykom szkół w Polsce...”. Myśli o wychowaniu Henryka Wiercieńskiego s. 123-133; Czarnecka I.: Jan Papłoński - rektor warszawskiego Instytutu Głuchoniemych i Ociemniałych s. 133-143; Kula Ewa: Warszawska Szkoła Rabinów w protokołach posiedzeń Rady Wychowania Publicznego w latach 1845-1850 s. 144-156; Gliński Waldemar: Formacja intelektualna i ascetyczna w Seminarium Głównym Warszawskim s. 157-163; Stawiak-Ososińska Małgorzata: Początki kształcenia akuszerek w Częstochowie s. 164-173; Kempa Grażyna: Formy edukacji żeńskiej w Królestwie Polskim (1815-1864) na tle poglądów naukowych i publicystycznych s. 174-189; Jaszczyszyn Elżbieta, Dąbrowska Joanna E.: Instytut Rządowy Wychowania Płci Żeńskiej z perspektywy XXI wieku s. 190-197; Kulbaka Jacek: Tradycje kształcenia specjalnego w Królestwie Polskim s. 198-215; Bołdyrew Aneta: Opieka i wychowanie dzieci osieroconych w Królestwie Polskim na przełomie XIX i XX wieku s. 216-226; Wolter Edyta: Wychowanie do ochrony przyrody w Królestwie Polskim (w latach 1910-1914) s. 227-236; Galek Czesław: Wychowanie młodzieży szkolnej w Królestwie Polskim na przełomie XIX i XX wieku w świetle literatury memuarystycznej i beletrystycznej s. 237-248.

185. SZMYT Andrzej: Russia's educational policy aimed at the Poles and the Polish territories annected during the reign of tsar Alexander I. Przeglad Wschodnioeuropejski. [T.] 7: 2016 [nr] 1 s. $11-28$.

186. SZMYT A.: Wpływ idei Komisji Edukacji Narodowej na organizację szkolnictwa w Rosji w pierwszej połowie XIX wieku. Studia Paedagogica Ignatiana. Vol. 19: 2016 [nr] 3 s. 55-78.

187. SZPYTMA Cezary: Szkoły typu Open-Air: eksperymenty architektoniczno-pedagogiczne szkolnictwa w pierwszym dziesięcioleciu XX wieku. Problemy Wczesnej Edukacji. R. 11: 2013 nr 4 s. $23-41$.

188. ŚPICA Paweł: Kierunki działalności edukacyjnej organizacji polskich w Prusach Zachodnich na przełomie XIX i XX wieku. Studia Paedagogica Ignatiana. Vol. 19: 2016 [nr] 2 s. 171-191.

189. ŚPICA P.: Wychowanie domowe i edukacja szkolna dzieci polskich w Prusach Zachodnich w połowie XIX wieku w świetle czasopisma „Nadwiślanin” i dodatku pt. „Gospodarz”. Przegląd Historyczno-Oświatowy. R. 59: 2016 nr 3/4 s. 57-72.

190. TOPIJ-STEMPIŃSKA Beata: Źródła do działalności edukacyjnej konwiktu szlacheckiego w Tarnopolu. Studia Paedagogica Ignatiana. Vol. 19: 2016 [nr] 3 s. 227-241.

W 1. 1820-1886. 
191. WALASEK Stefania: Nauczycielki i działaczki oświatowe w Wilnie na przełomie XIX i XX wieku. [W:] Kobiety na Kresach na przełomie XIX i XX wieku. Pod red. nauk. Adriany Dawid i Joanny Lusek. Warszawa 2016 s. 61-72.

192. WAŁEK Bożena: Czytelnie uczniowskie i kółka naukowe w procesie kształcenia i wychowania uczniów w galicyjskich szkołach średnich (w świetle sprawozdań szkolnych z lat 1904-1917). Nowa Biblioteka. 2016 nr 3 s. 65-90.

193. WAŁĘGA Agnieszka: „Szkoła” źródłem w badaniach historyczno-pedagogicznych polskich instytucji edukacyjnych doby zaborów. Studia Paedagogica Ignatiana. Vol. 19: 2016 [nr] 2 s. $253-270$.

194. WĄSACZ-KRZTOŃ Jolanta, Posłuszna Joanna: Kształcenie muzyczne młodzieży w Galicji Zachodniej w dobie autonomii. Annales UMCS. Sec. J: Paedagogia-Psychologia. Vol. 29: 2016 [nr] 3 s. 149-159.

195. WESOŁOWSKA Małgorzata: Uczelnie galicyjskie doby autonomii. Zeszyty Naukowe Uniwersytet Ekonomiczny w Krakowie. 2016 nr 12 s. 107-124.

196. WINIARZ Adam: Literatura pedagogiczna nauczyciela szkoły elementarnej w Księstwie Warszawskim i Królestwie Polskim (1807-1831). Prace Naukowe Akademii im. Jana Dlugosza. Pedagogika. T. 25: 2015 nr 2 s. 361-374.

197. WITT Bronisław: Jerzy Benjamin Flatt (1768-1860) ze Skoków i początki polskiej wyższej uczelni rolniczej. Wangrovieciana Studia et Fontes. T. 3: 2016 s. 101-109.

198. ZIMMERMANN Peter: Uwarunkowania historyczne roli i statusu języka polskiego w systemie edukacji Galicji 1. połowy XIX wieku. Poznańskie Studia Polonistyczne. Ser. Językoznawcza. T. 23: 2016 z. 2 s. 245-262.

199. ZJAWIN Jacek: Koncepcja wychowawcza Edmunda Bojanowskiego na tle prądów pedagogicznych dziewiętnastego wieku. Katecheza, Rodzina, Parafia i Szkoła. T. 14: 2016 s. 55-64.

200. ZUBIŃSKI Paweł: Życie oświatowe i kulturalne Suchedniowa pod koniec XIX i na początku XX wieku. Zeszyty Suchedniowskie. [T.] 1: 2016 s. 11-35.

\section{Okres 1918-1939}

201. BAJERSKI Artur: Szkolnictwo wyższe międzywojennej Polski. Ujęcie geograficzne. Poznań 2016 Wydaw. Nauk. UAM ss. 198, nlb. 1, il. UAM w Poznaniu. (Geografia; nr 97).

202. BARNAŚ-BARAN Ewa: Działalność opiekuńcza Krakowskiego Towarzystwa Dobroczynności w latach 1919-1939. Studia i Prace Pedagogiczne. Nr 2: 2015 s. 213-224.

203. [CARIK Ol'ga] Tsaryk Olga: Założenia i praktyka kształcenia językowego uczniów w szkołach polskich okresu międzywojennego. Studia i Prace Pedagogiczne. Nr 3: 2016 s. 211-220.

204. CHODKOWSKA Maria, Bednarz-Grzybek Renata: Problemy adaptacji dziecka w okresie międzywojennym. Biuletyn Historii Wychowania. [Nr] 34: 2016 s. 37-55.

205. CYWIŃSKA Marta: Misja narodowa szkoły i nauczyciela. Na podstawie „Dydaktyki ogólnej” oraz „O zadaniach nauczyciela polskiego” Lucjana Zarzeckiego. Glaukopis. Nr 33: 2016 s. 361-373. 
206. CYWIŃSKA M.: Rola prasy młodzieżowej i dziecięcej w edukacji oraz wychowaniu patriotycznym. Na przykładzie zbiorów Domu Kresowego w Białymstoku. Glaukopis. Nr 34: 2016 s. $41-58$.

Lata $1918-1939$.

207. CZEPCZYŃSKA Emilia: Kształtowanie się jednolitego systemu oświaty w II Rzeczypospolitej. Studia Prawnicze KUL. [T.] 4: 2016 s. 33-51.

208. DĄBROWSKI Karol: Działalność oświatowa samorządu przemysłowo-handlowego w latach 1929-1939 na przykładzie Izby Przemysłowo-Handlowej w Lublinie. Studia z Dziejów Państwa i Prawa Polskiego. [T.] 19: 2016 s. 297-314.

209. DIAGNOZA i postulaty zmian w szkolnictwie wyższym na podstawie wybranych fragmentów wypowiedzi uczestników II Zjazdu Naukowego w 1927 roku. Wybór i oprac. Dorota Pauluk. Polska Myśl Pedagogiczna. Nr 2: 2016 s. 427-439.

210. DZIENIAKOWSKA Jolanta: Czasopismo „Oświata i Wychowanie” (1929-1939) w systemie prasowym władz szkolnych Drugiej Rzeczypospolitej. Przeglad Historyczno-Oświatowy. R. 59: 2016 nr 3/4 s. 104-121.

211. GOŁDYN Piotr: Działalność Państwowego Instytutu Robót Ręcznych w Warszawie w świetle protokołów rad pedagogicznych. Studia Paedagogica Ignatiana. Vol. 19: 2016 [nr] 2 s. $123-143$.

W 1. 1928-1939.

212. GRZYBOWSKI Romuald: Szkic do portretu edukacji gdyńskiej: okoliczności powstania i rozwój szkół zawodowych w Gdyni w latach Drugiej Rzeczypospolitej. Przegląd Historyczno-Oświatowy. R. 59: 2016 nr 3/4 s. 87-103.

213. GUCIA Dobrosława: Jeżyccy darczyńcy Towarzystwa Naukowej Pomocy im. Karola Marcinkowskiego w 1921 roku. Kronika M. Poznania. 2016 [nr] 4 s. 172-177.

Dla młodzieży męskiej.

214. HENSCHE Eleonora: Wychowanie i kształcenie sióstr Zgromadzenia zmartwychwstania Pańskiego w archidiecezji poznańskiej w latach 1919-1939. Nasza Przeszłość. T. 126: 2016 s. $321-375$.

215. IZDEBSKI Paweł: Metody psychologii dziecka i ich praktyczne zastosowania w odrodzonej Polsce w ujęciu Anieli Szycówny [1869-1921]. Studia Psychologica. R. 15: 2016 t. 1 s. 35-45.

216. KALINOWSKA-WITEK Barbara: Dla dobra szkoły i „dla dobra służby”... Kwestie ustrojowe szkolnictwa i sprawy zawodowe nauczycieli w czasopismach Towarzystwa Nauczycieli Szkół Średnich i Wyższych oraz Związku Zawodowego Nauczycielstwa Polskich Szkół Średnich (1918-1939). Lublin 2016 Wydaw. UMCS ss. 432, il.

217. KALINOWSKA-WITEK B.: Troska o wychowanie - w poglądach i działalności pedagogów II Rzeczypospolitej (1918-1939). Lubelski Rocznik Pedagogiczny. Vol. 35: 2016 no 1 s. 259-272.

218. KRÓL Joanna: Reforma oświatowa z 1934 roku: uwarunkowania społeczne, założenia i realizacja. Prace Naukowe Akademii im. Jana Dlugosza. Pedagogika. T. 24: 2015 s. 555-566. 
219. KRYCHNIAK Ewa: Oświata i kultura żydowska Białostocczyzny okresu międzywojennego i jej wyniszczenie podczas II wojny światowej. Sokółka-Mielec 2016 Agencja Wydawnicza „Promocja” ss. 329, il.

220. ŁAPOT Mirosław: Formowanie kompetencji kulturowych dziecka żydowskiego w Polsce międzywojennej na przykładzie czasopisma „Nasza Jutrzenka” (1921-1939). Prace Naukowe Akademii im. Jana Dlugosza. Pedagogika. T. 25: 2015 nr 2 s. 447-439.

221. ŁAPOT M.: Od szkoły rabinów do kursów hebrajskich we Lwowie (1828-1939). Kwartalnik Historii Żydów. 2016 nr 4 s. 827-843.

222. ŁAPOT M.: Wychowanie patriotyczno-obywatelskie w szkole żydowskiej w okresie międzywojennym (na przykładzie Lwowa). Prace Naukowe Akademii im. Jana Dtugosza. Pedagogika. T. 25: $2015 \mathrm{nr} 1$ s. 603-620.

223. MAGIERA Elżbieta: Wykorzystanie programów nauczania szkół powszechnych po reformie z 1932 roku w kształceniu i wychowaniu spółdzielczym. Prace Naukowe Akademii im. Jana Dlugosza. Pedagogika. T. 24: 2015 s. 539-554.

224. MARKIEWICZ Renata: Dydaktyka i wychowanie w szkołach wiejskich w okresie dwudziestolecia międzywojennego na przykładzie szkół powszechnych gminy Garbów. Biuletyn Historii Wychowania. [Nr] 34: 2016 s. 117-133.

225. MUCHA Krzysztof: Organizacja i struktura administracji szkolnej na terenie województwa łódzkiego w okresie międzywojennym. Rocznik Łódzki. T. 64: 2016 s. 197-212.

226. NIEDOJADŁO Andrzej: Postacie bohaterów narodowych Polski oraz Europy i świata, związanych z Polską występujące w obchodach uroczystości państwowych w szkolnictwie powszechnym II Rzeczypospolitej w latach 1918-1926 na przykładzie Okręgu Szkolnego Krakowskiego. Tarnowskie Studia Historyczne. T. 4: 2014 s. 92-100.

227. NIEWĘGŁOWSKI Jan: Towarzystwo Salezjańskie wobec potrzeb szkolnictwa zawodowego w okresie międzywojennym. Seminare. T. 37: 2016 nr 1 s. 39-51.

228. NIEWĘGŁOWSKI J.: Towarzystwo Salezjańskie wobec wyzwań edukacyjnych w latach 1918-1939. Seminare. T. 36: 2015 nr 1 s. 151-162.

229. PIWOWARCZYK Mirosław: Kobiety aktywne - działalność społeczno-oświatowa liderek Wileńskiego Zrzeszenia Wojewódzkiego Związku Pracy Obywatelskiej Kobiet (1929-1939). [W:] Kobiety na Kresach na przełomie XIX i XX wieku. Pod red. nauk. Adriany Dawid i Joanny Lusek. Warszawa 2016 s. 43-60.

230. POLESIAK Krzysztof: Działalność Arnolda Kriedte w grudządzkim Deutsche Schulverein in Polen. Rocznik Grudziądzki. T. 23: 2015 s. 231-248.

Lata 1919-1934.

231. POZNAŃSKI Jarosław: Szkolnictwo powszechne w gminie Zwierzyniec w latach 1918-1939. Zwierzyniec 2014 Wydaw. Lipiec ss. 128, il.

232. PREGIEL Piotr: Wkroczenie nazizmu do środowiska studenckiego Technische Hochschule Breslau w 1933 roku. Rocznik Wroctawski. R. 13/14: 2016 s. 23-45.

233. PRZENIOSŁO Małgorzata: Habilitacja z pedagogiki w II Rzeczypospolitej. Przeglad Pedagogiczny. $2016 \mathrm{nr} 1$ s. 41-55. 
234. RĘDZIŃSKI Kazimierz: Kontrowersje i konflikty w środowisku studenckim we Lwowie w latach 1919-1939. Prace Naukowe Akademii im. Jana Dlugosza. Pedagogika. T. 25: 2015 nr 2 s. $435-447$.

235. RĘDZIŃSKI K.: Studenci żydowscy we Lwowie w latach 1918-1939. Prace Naukowe Akademii im. Jana Dlugosza. Pedagogika. T. 25: 2015 nr 1 s. 581-601.

236. RĘDZIŃSKI K.: Studenckie protesty antyopłatowe oraz w obronie autonomii uczelni we Lwowie w latach 1932-1939. Rocznik Polsko-Ukraiński. T. 18: 2016 s. 31-44.

237. RYNIO Alina, Pabiniak Alina: Historyczno-kulturowe tło rozwoju pedagogiki katolickiej w Polsce w dwudziestoleciu międzywojennym. [W:] Język i wychowanie. Księga jubileuszowa z okazji 45-lecia pracy naukowej profesor Kazimiery Krakowiak. Red. Ewa Domagała-Zyśk, Aleksandra Borowicz, Renata Kołodziejczyk. Lublin 2016 s. 663-681.

238. RYPEL Agnieszka: Dziecko w czasie przełomu - obraz młodocianych mieszkańców Pomorza w „Dzienniku Bydgoskim” z roku 1920. [W:] Dziecko. Literatura, sztuka, język. Pod red. Romana Starza. Kielce 2016 s. 422-444.

239. RZEPKA Magdalena: Wychowanie lotnicze w II Rzeczypospolitej - stan badań i perspektywy badawcze. Rozprawy z Dziejów Oświaty. T. 53: 2016 s. 95-111.

240. SIECIŃSKI Wiesław: Administracja i organizacja szkolnictwa powszechnego i średniego w II Rzeczypospolitej. Studia Administracyjne. Nr 8: 2016 s. 79-97.

241. SKALSKI Piotr, Pękacka-Falkowska Katarzyna: Poznańscy studenci farmacji w latach 1920-1939. Studium z zakresu historii społecznej. Analecta. R. 25: 2016 z. 2 s. 139-195.

242. SŁAWOMIR Czerwiński i wychowanie państwowe. Pod red. Piotra Gołdyna. Kalisz 2016 Kaliskie Tow. Przyj. Nauk ss. 216, il. Książnica Pedagog. im. Alfonsa Parczewskiego w Kaliszu.

Treść: Gołdyn P.: Wstęp s. 7-9; Jakubiak Krzysztof: Trwałe wartości i współczesne konotacje wychowania państwowego z okresu II Rzeczypospolitej s. 11-17; Walczak Krzysztof: Kalisz Sławomira Czerwińskiego. Instytucje, ludzie, wydarzenia s. 21-30; Andrysiak Ewa: Książka w życiu Sławomira Czerwińskiego s. 31-51; Durka Jarosław: Ks. Bronisław Żongołłowicz jako wiceminister oświaty w latach 1930-1931 s. 52-72; Król Joanna: Kontrowersje wokół ideału wychowania państwowego Sławomira Czerwińskiego (1885-1931) s. 75-96; Magiera Elżbieta: Organizacja wychowania państwowego w szkolnictwie powszechnym Drugiej Rzeczypospolitej w latach 1932-1939 s. 97-122; Gumuła Teresa: Czasopisma pedagogiczne i oświatowe o wychowaniu państwowym w latach 1928-1933 s. 123-145; Samsel Agata: Wychowanie państwowe w przedszkolach II Rzeczypospolitej na łamach miesięcznika „Przedszkole” (1933-1939) s. 146-173; Wróblewska Urszula: Karaimi wobec form wychowania państwowego w Drugiej Rzeczypospolitej s. 174-191; Grysińska-Jarmuła Katarzyna: Czy Polaków można było skutecznie zgermanizować i zrobić z nich przykładnych obywateli państwa pruskiego (Cesarstwa Niemieckiego)? Uwagi na temat założeń zawartych w memoriałach Bogdana Hutten-Czapskiego s. $195-216$.

243. SZTEJNBIS-ZDYB Joanna: Pieśń szkolna w polskiej praktyce pedagogicznej okresu międzywojennego. Zamojskie Studia i Materiały. Ser. Pedagogika. T. 18: 2016 z. 1 s. 39-59.

244. TANEWSKI Paweł: Gospodarcze i społeczne aspekty polityki oświatowej władz II Rzeczypospolitej. Glaukopis. Nr 31: 2014 s. 313-332.

245. WOLTER Edyta: Edukacja ekologiczna w Drugiej Rzeczypospolitej inspiracją dla praktyki edukacyjnej w XXI wieku. Biuletyn Historii Wychowania. [Nr] 34: 2016 s. 71-83. 
246. WÓJCIK Grażyna: Działalność kulturalno-oświatowa ks. dr. Juliana Młynarczyka w świetle artykułów czasopisma „Brzask” (Mariówka Opoczyńska 1926-1939). Fides. [R. 22]: 2016 nr 1 s. $85-112$.

247. WÓJCIK-ŁAGAN Hanna: Szkoła z lat 20. XX w. w oczach Władysława Bieńkowskiego, autora powojennych koncepcji edukacyjnych z lat 40. i 50. XX w. Przeglad Historyczno-Oświatowy. R. 59: $2016 \mathrm{nr}$ 1/2 s. 103-123.

248. WYSZCZELSKI Lech, Niewęgłowska Aneta: Korpusy kadetów w Polsce (1918-1939). Kwartalnik Bellona. R. 10: 2016 nr 3 s. 167-182.

249. ZALAS Katarzyna: Innowacje pedagogiczne w częstochowskim szkolnictwie powszechnym okresu międzywojennego. Prace Naukowe Akademii im. Jana Dtugosza. Pedagogika. T. 25: 2015 nr 1 s. 669-682.

\section{Okres $1939-1945$}

250. GAŁĘZOWSKI Marek: Polskie sieroty. Los dzieci polskich na nieludzkiej ziemi. Warszawa 2016 Edipresse Polska ss. 89, nlb. 1, il. (Szlak Andersa. Kronika niezwykłego marszu przez trzy kontynenty; t. 13).

251. GŁOWACKI Albin: Problemy edukacji dzieci polskich zesłańców (1941-1946). Przegląd Historyczno-Oświatowy. R. 59: 2016 nr 1/2 s. 173-193.

252. GRABOWSKA-PIEŃKOSZ Dorota: Polityka Trzeciej Rzeszy wobec polskiej inteligencji z Uniwersytetu Jagiellońskiego. Studia Historyczne. R. 58: 2015 z. 4 s. 497-513, sum.

253. GRALAK Bronisław: Szkolnictwo akademickie i nauka polska w okresie okupacji hitlerowskiej. Wyd. 2 popr. i uzup. Zgierz 2016 Bronisław Gralak ss. 302.

Wyd. 1. 2010.

254. KRAWIEC Jan: Organizacja tajnych studiów filozoficznych i teologicznych oraz nowicjatu w Inspektorii św. Jacka w Polsce podczas drugiej wojny światowej 1939-1945. Kraków 2015 Poligrafia Salezjańska ss. 201.

Rec.: Szlufik Piotr, Archiwa, Biblioteki i Muzea Kościelne. T. 106: 2016 s.427-429.

255. SZUSTER Gabriel: Tajna szkoła w Generalgouvernement 1939-1945. Studium przypadku - Gmina Krzeszowice. Rocznik Komisji Nauk Pedagogicznych. R. 68: 2015 s. 143-160.

256. ŚLIWAK Katarzyna: Activities of Fr. Zygmunt Kaczynski - Minister of Religious Affairs and Public Education in the government-in-exile (1943-1945). Przeglad Historyczno-Oświatowy. R. 59: $2016 \mathrm{nr}$ 3/4 s. 196-208.

Zygmunt Kaczyński (1894-1953) 


\section{Okres 1945-1989}

257. BANAŚ Konrad, Gawryszczak Marcin, Lesiakowski Krzysztof: Strajk studencki w Łodzi. Styczeń - luty 1981 r. Okruchy pamięci, zapisy źródłowe, ikonografia. Łódź-Warszawa 2016 Wydaw. UŁ; Nar. Centrum Kultury ss. 425, il.

258. BARTCZAK Anna: Szkolnictwo dla dzieci narodowości niemieckiej na Pomorzu Zachodnim w latach 1945-1964. Stargardia. T. 10: 2015 [dr.:] 2016 s. 297-313.

259. BRENK Mikołaj: Kształcenie pracowników socjalnych w Polsce Ludowej. Studia Edukacyjne. Nr 31: 2014 s. 233-248.

260. BUJKIEWICZ Zbigniew: Stan zielonogórskiego szkolnictwa w listopadzie 1945 roku w świetle protokołów poinspekcyjnych wizytatora Wiesława Sautera. Studia Zielonogórskie. T. 21: 2016 s. $183-194$.

261. BYKOWSKA Beata: Kształcenie nauczycieli w okresie PRL. Zeszyty Naukowe Gdańskiej Szkoły Wyższej. Nr 13: 2013 s. 224-261.

262. EDUKACJA w PRL. Pod red. Moniki Wiśniewskiej. Warszawa 2016 Wydaw. Uniw. Kardynała Stefana Wyszyńskiego ss. 263, nlb. 1, tabl. 7, il. (W Służbie Niepodległej).

Treść: Żaryn Jan: Edukacja w warunkach zniewolenia s. 7-9; Herman Aneta: Studenci Politechniki Łódzkiej wobec systemu oświaty na przykładzie strajku studentów w styczniu i lutym 1981 r. s. 13-28; Stępniak Aleksander: Szkolnictwo wyższe w okresie PRL - przekreślenie autonomii uniwersytetu s. 29-54; Rysak Leszek: Powstanie PZPR oraz uchwalenie Konstytucji PRL w nauczaniu historii w szkołach w Polsce Ludowej w latach 50. i 60. w oparciu o podręczniki i programy szkolne - zarys problemów badawczych s. 57-68; Paluch Micha': Wielostronne manipulacje twórcy wielostronnej teorii kształcenia s. 69-112; Dobrzycka Joanna: Łacina w PRL s. 113-122; Brzeźniak Karolina: Wpływ komunizmu na edukację historyczną w szkole w latach 1944-1956 s. 123-134; Ratyńska Patrycja: Rehabilitacja nauczycieli w Polsce po 1956 roku s. 135-152; Klich Daria: Urszulanki Unii Rzymskiej w trosce o wychowanie dzieci i młodzieży w czasach PRL s. 155-178; Opiela Maria: Społeczno-polityczne uwarunkowania działalności ochronkowej Sióstr Służebniczek BDNP-dębickich w latach 1954-1980 s. 179-197; Strzelecka Aleksandra: Liceum Ogólnokształcące Sióstr Urszulanek Unii Rzymskiej w Poznaniu s. 199-219; Wiśniewska Monika: „Szkoła należy do państwa, a nie do Kościoła”. Między polityką wyznaniową a oświatową Władysława Gomułki s. 219-236; Kołakowski Andrzej: Działalność Milicyjnej Izby Zatrzymań dla Nieletnich w Gdańsku w latach 1950-1957 w kontekście zadań i celów wyznaczonych przez politykę państwa s. 239-252; Wiśniewska M., Mieczkowski Robert: Sprawozdanie z ogólnopolskiej konferencji naukowej „Edukacja w warunkach zniewolenia. Polityka oświatowa w PRL” [Warszawa, 11 III 2016 r.] s. 253-264.

263. FIRLEJ Waldemar, Majewski Stanisław: Odbudowa szkolnictwa wyższego w Polsce w nowej rzeczywistości społeczno-politycznej po II wojnie światowej. Studia Pedagogiczne. T. 26: 2015 s. $57-74$.

264. GORLOFF Elżbieta: Doskonalenie zawodowe nauczycieli edukacji wczesnoszkolnej w świetle reformy oświatowej z 1961 roku. Prace Naukowe Akademii im. Jana Dhugosza. Pedagogika. T. 25: $2015 \mathrm{nr} 2$ s. 469-485.

265. GORLOFF E.: Organizacje społeczne i ideowo-wychowawcze w życiu codziennym szkół podstawowych województwa gdańskiego (1945-1956). Prace Naukowe Akademii im. Jana Dtugosza. Pedagogika. T. 24: 2015 s. 567-581.

266. GRZYBOWSKI Romuald: Laicyzacja szkoły jako forma walki władz komunistycznych z Kościołem katolickim i obecnością religii w wychowaniu dzieci i młodzieży w latach 1944-1956. Prace Naukowe Akademii im. Jana Dlugosza. Pedagogika. T. 25: 2015 nr 1 s. 559-579. 
267. GRZYBOWSKI R.: Obraz młodzieży polskiej z przełomu lat pięćdziesiątych i sześćdziesiątych XX wieku w świetle badań pedagogicznych. Prace Naukowe Akademii im. Jana Dlugosza. Pedagogika. T. 24: 2015 s. 583-598.

268. GRZYBOWSKI R.: Zasady doboru asystentów wyższych szkół pedagogicznych jako egzemplifikacja założeń polityki kadrowej PZPR realizowanej na terenie szkolnictwa wyższego w Polsce w okresie stalinowskim. Studia i Badania Naukowe - Ateneum Szkoła Wyższa w Gdańsku.

R. 8: 2014 nr 1 s. $29-43$.

269. JANUSZEWSKA-WARYCH Maria: „Głos Nauczycielski” 1945 r. W stulecie Centralnego Organu Związku Nauczycielstwa Polskiego. Rocznik Polsko-Ukraiński. T. 18: 2016 s. 45-66.

270. JAWORSKI Wojciech: Żydowska oświata ogólnokształcąca na Górnym Śląsku w latach 1945-1964. Rocznik Muzeum w Gliwicach. T. 26: 2016 s. 103-117.

271. „JESZCZE zwyciężymy...”. 35-lecie strajku studenckiego w Wyższej Szkole RolniczoPedagogicznej w Siedlcach. Materiały i wspomnienia z lat 1980-1991. Red. i oprac. nauk. Jarosław Cabaj, Jerzy Ireneusz Cabaj, Roman Głowacki. Siedlce 2016 Wydaw. Uniw. Przyrodniczo -Humanist. ss. 256, il. Uniw. Przyrodniczo-Humanist. w Siedlcach. Wydz. Humanist. Inst. Historii i Stosunków Międzynar.

272. KĘPIŃSKI Marcin: Pomiędzy pamięcią autobiograficzną a zbiorową. Polska Ludowa i stan wojenny w narracji łódzkich nauczycieli. Łódź 2016 Wydaw. UŁ ss. 558, nlb. 1.

273. KOLBUSZEWSKA Jolanta: Akademickie kariery kobiet w PRL-u. Historyczki - samodzielne pracownice nauki w nowopowstałych uniwersytetach. Sensus Historiae. Vol. 24: 2016 no 3 s. $153-172$.

274. KOŁAKOWSKI Andrzej: Pomoc czy przemoc? Krytyczne sytuacje w zakładach poprawczych w okresie PRL na przykładzie Zakładu Poprawczego i Schroniska dla Nieletnich w Oryszewie. Rocznik Polsko-Ukraiński. T. 18: 2016 s. 15-31.

275. KOŁAKOWSKI A.: Postawy i wybory moralne młodych Polaków w latach 80. XX wieku w świetle poufnych raportów PZPR i SB. Prace Naukowe Akademii im. Jana Dlugosza. Pedagogika. T. 25: $2015 \mathrm{nr} 2$ s. 487-500.

276. KOŚCIÓŁ a młodzież w Polsce po II wojnie światowej. Pod. red. Pawła Nowogórskiego, Wojciecha Polaka, Waldemara Rozynkowskiego. Toruń-Górsk 2016 Fund. Centrum Edukacji Młodzieży im. ks. Jerzego Popiełuszki ss. 154, il. (Roczniki Księdza Jerzego; t. 1).

Treść: Nowogórski P., Polak Wojciech, Rozynkowski W.: Wstęp s. 5-6; Rozynkowski W.: Ruchy i stowarzyszenia katolickie w Polsce po II wojnie światowej - zarys problematyki badawczej na przykładzie Sodalicji Mariańskiej w Grudziądzu s. 7-17; Polak W.: Działania Służby Bezpieczeństwa wobec młodzieży związanej z duszpasterstwami akademickimi w Toruniu w okresie PRL s. 19-57; Wąsowicz Jarosław: ksiądz Jerzy Popiełuszko jako wychowawca i opiekun młodzieży s. 59-88; Konopka Witold: Represje wobec młodzieży na przykładzie wizyt pasterskich Prymasa Polski Stefana Wyszyńskiego w granicach obecnego województwa kujawsko-pomorskiego s. 89-96; Łatka Rafał: Kardynał Karol Wojtyła jako animator duszpasterstwa akademickiego s. 97-108; Nowogórski P.: Poświęcenie i otwarcie Centrum Edukacji Młodzieży im. ks. Jerzego Popiełuszki w Górsku (17 października 2014 r.) s. 109-117; Kłosińska Justyna: Kronika Centrum Edukacji Młodzieży im. ks. Jerzego Popiełuszki w Górsku (2014-2015) s. 119-131; [Fotografie] s. 133-154.

277. KRUK Marek: Powstanie i działalność Szkolnego Związku Sportowego, założenia programowe, struktura organizacyjna i realizacja uchwał I Zjazdu Delegatów SZS. [W:] Kultura fi- 
zyczna w Polsce Ludowej. Pod red. Leonarda Nowaka, Tomasza Jurka. Gorzów Wielkopolski 2016 s. $69-82$.

278. MAŁOLEPSZY Eligiusz, Drozdek-Małolepsza Teresa: Rola i znaczenie turystyki w wychowaniu i kształceniu dzieci i młodzieży w działalności Zrzeszenia Ludowe Zespoły Sportowe (po 1975 r.). Zarys problematyki. Prace Naukowe Akademii im. Jana Dlugosza. Pedagogika. T. 24: 2015 s. 641-652.

279. MĘTRAK Dorota Anna: Przemiany organizacyjne szkolnictwa plastycznego w Polsce w latach 1945-1990 w świetle uregulowań prawnych. Prace Naukowe Akademii im. Jana Dlugosza. Pedagogika. T. 25: 2015 nr 2 s. 521-536.

280. MŁODZIEŻ antysystemowa w Polsce południowo-wschodniej w latach 1957-1989. Wybór dokumentów. Wstęp i oprac. Bogusław Wójcik. Rzeszów 2016 IPN - KŚZpNP. Oddz. ss. 660, tabl. 16, il. (Seria Wydawnicza IPN Oddział w Rzeszowie).

281. MUSIAŁ Marcin: „Inteligentny i zdolny rzemieślnik to przyszłość państwa ludowego”. Państwo i Kościół w procesie wychowania młodzieży w latach 1945-1951 na przykładzie Prywatnego Salezjańskiego Męskiego Gimnazjum Krawieckiego we Wrocławiu. Nasza Przeszłość. T. 126: 2016 s. 417-439.

282. PACIOREK Magdalena: Studenci wydziałów lekarskich w Polsce w latach 1944/1945-1948/1949. Kształtowanie i rozwój środowiska. Warszawa 2016 IHN PAN; Aspra-JR ss. 406, il.

283. PULIŃSKA Urszula: Nadzór ideologiczny organów partyjnych nad nauczycielami na Warmii i Mazurach w latach 1945-1948. Studia Edukacyjne. Nr 32: 2014 s. 321-341.

284. SAPIA-DREWNIAK Eleonora: „Kwartalnik Nauczyciela Opolskiego” (1958-1991). Przeglad Historyczno-Oświatowy. R. 59: 2016 nr 1/2 s. 124-141.

285. [SUHOMLIN'SKA Ol'ga Vasìlivna] Sukhomlynska Olga: Ukrainian and Polish pedagogical influences in the historical dimension. The case of Vasyl Sukhomlynskyi. Annales UMCS. Sec. J: Paedagogia-Psychologia. Vol. 29: 2016 [nr] 2 s. 133-138.

Vasilij Aleksandrovič Suhomlin'skij (1918-1970)

286. SYCHOWICZ Krzysztof: Studenci uczelni białostockich jako przedmiot działań operacyjnych Służby Bezpieczeństwa w latach 1980-1989. Glaukopis. Nr 29: 2013 s. 92-110.

287. ŚLIWIAK Katarzyna: Organizacja i historia szkolnictwa podstawowego w Żaganiu w latach 1945-1956. Ogrody Nauk i Sztuk. T. 6: 2016 s. 339-347.

288. TECHMAŃSKA Barbara: Szkolnictwo dla mniejszości narodowych na Dolnym Śląsku w okresie PRL. Wybrane zagadnienia. Klio. T. 31: 2016 s. 17-55.

289. TO IDZIE młodość. Młodzież w ideologii i praktyce komunizmu. Pod red. Dariusza Magiera. Lublin-Radzyń Podlaski 2016 AP; Tow. Nauki i Kultury Libra ss. 467, il.

Z treści: Magier D.: Słowo wstępne s. 9-12; Idzikowska-Czubaj Anna: „Szczęśliwe pokolenie Polski Ludowej”, czyli o komunistycznym micie młodości s. 15-27; Czyżewski Andrzej: „Młodzi”, „,niewinni”, „bohaterscy”, „nasi” - wojenna martyrologia polskiej młodzieży jako element komunistycznej polityki pamięci historycznej s. 29-45; Su’awka Adam Radosław: „Mołodoj Kommunist” („Małady Kommunist”) jako organ prasowy Centralnego Komunistycznego Związku Młodzieży Zachodniej Białorusi [w Wilnie, w 1. 1924-1937] s. 101-111; Borek Paweł: Agitacja komunistyczna wśród poborowych w Polsce międzywojennej s. 113-127; Zackiewicz Grzegorz: Komunistyczna infiltracja środowisk młodzieży syndykalistycznej w II Rzeczypospolitej s. 129-145; Wróbel Andrzej: Proces tomaszowski działaczy Komunistycznego Związku Młodzieży Polski przed sądem Okręgowym w Piotrkowie Trybunalskim s. 147-167; Bertram Łukasz: Wyrastanie z pałacu. Ana- 
liza narracji biograficznej Marii Kamińskiej s. 171-192; Świętochowska Emilia: Uroczystości szkolne jako forma indoktrynacji dzieci i młodzieży w latach 1944-1956 s. 193-206; Sroka Marcin: Młodzież w polityce KW PZPR w Opolu w latach 1950-1990 s. 207-224; Bober Sabina: Niezależne organizacje młodzieżowe na celowniku władzy komunistycznej w pierwszych latach Polski Ludowej s. 225-237; Kruszyński Marcin: „Długie trwanie niemocy". Ideowe organizacje studenckie na przykładzie lubelskiego UMCS. Wybrane sprawy s. 241-257; Rokicki Konrad: Nadzór polityczny nad działalnością klubów studenckich w latach 1956-1980. Casus Warszawy s. 259-282; Wojcieszyk Elżbieta: Zrzeszenie Katolików przy Wyższej Szkole Rolniczej w Poznaniu i Studencki Komitet Pomocy dla Więźniów Politycznych (1956-1960) s. 283-296; Łatka Rafał: Duszpasterstwo akademickie w polityce władz PRL w latach 1970-1989 na przykładzie województwa krakowskiego s. 297-321; Szumiło Mirosław: Szefowie młodzieżówki komunistycznej w Polsce 1944-1990 s. 325-342; Gończyński-Jussis Filip: Szkolne Koła Towarzystwa Przyjaźni Polsko-Radzieckiej (1980-1990): założenia i praktyka działania s. 343-360; Matuszak Tomasz: Działalność młodzieży w ramach Towarzystwa Przyjaźni Polsko-Radzieckiej na terenie województwa piotrkowskiego w latach 1975-1990 s. 361-379; Hubka Maciej Roman: Związek Socjalistycznej Młodzieży Polskiej w województwie piotrkowskim. Zarys dziejów i pozostałość aktowa s. 381-396; Leszkowicz Tomasz: Historyczna tabula rasa? Zabiegi aparatu propagandowego PRL w latach 60. XX wieku na rzecz zaszczepienia młodzieży „,nowej pamięci” s. 399-415; Tracz Bogusław: Powstrzymać „dywersję moralną Zachodu”. Partia komunistyczna wobec przemian kultury młodzieżowej w Polsce w latach 60. i 70. XX wieku s. 417-441; Magier D., Mroczek Michał: Program „Awangarda XXI wieku” - w poszukiwaniu nowego modelu pasa transmisyjnego s. 443-467.

290. W TRYBACH systemu. Z dziejów łódzkiej opozycji studenckiej w latach 1968-1989. Pod red. Wiesława Maciejewskiego, Adama Hohendorffa, Janusza Mikosiaka. Warszawa 2016 Nar. Centrum Kultury ss. 422, nlb. 1, il. (Jubileusze).

291. WAROT Paweł Piotr: Uczelnia „R” 1968-1989, czyli Społeczność akademicka Olsztyna oczami Służby Bezpieczeństwa. Glaukopis. Nr 29: 2013 s. 52-91.

292. WIRSKI Adam: Szkolnictwo podstawowe w Koszalinie (1945-1989). Zeszyty Naukowe Koszalińskiej Wyższej Szkoły Nauk Humanistycznej. Z. 11: 2013 s. 99-133.

293. WOJTCZAK Krystyna: O stopniach naukowych w Polsce Ludowej. Cz. 1. Niższe stopnie naukowe. Studia Prawa Publicznego. 2016 s. 27-65.

Toż. Cz. 2. Organizacja aspirantury naukowej i studiów doktoranckich. Tamże nr 2 s. 49-92.

294. ZIMOCH-PIASKOWSKA Izabela: Opieka zakładów pracy nad liceami ogólnokształcącymi w Częstochowie w latach 1945-1989. Prace Naukowe Akademii im. Jana Dlugosza. Pedagogika. T. 25: $2015 \mathrm{nr} 2$ s. 501-519.

295. ZIMOCH-PIASKOWSKA I.: Pomoc materialna komitetów rodzicielskich w liceach ogólnokształcących w Częstochowie w latach 1945-1989. Rocznik Polsko-Ukraiński. T. 18: 2016 s. $129-141$.

296. ZIMOCH-PIASKOWSKA I.: Szkolnictwo średnie ogólnokształcące w Częstochowie w latach 1945-1989. Częstochowa 2016 Wydaw. im. Stanisława Podobińskiego Akad. im. Jana Długosza ss. 527. Akad. im. Jana Długosza.

297. ŻYCIE na przekór. Młodzieżowa kontestacja systemu w ostatniej dekadzie PRL (1980-1989) - nowe tropy i pytania badawcze. Red. Bartłomiej Noszczak. Warszawa 2016 IPN-KŚZpNP ss. 495, nlb. 1. IPN-KŚZpNP.

Treść: Noszczak B.: Wprowadzenie s. 7-14; Paleczny Tadeusz: Kontestacja młodzieżowa jako forma nieposłuszeństwa obywatelskiego s. 17-42; Hlebowicz Jan: Licealiści w karnawale „Solidarności”. Powstanie, działalność i znaczenie Ruchu Młodzieży Szkolnej s. 45-56; Gulczyńska Justyna: Szkolne Koła Oporu Społecznego jako egzemplifikacja działalności opozycyjnej młodzieży szkolnej w latach osiemdziesiątej s. 57-72; Król Joanna: Jak Dawid z Goliatem. Antysystemowe formy oporu licealistów w Szczecinie (1980-1989) - najważniejsze ustalenia i postulaty badawcze s. 73-84; Adamski Artur: Nie tylko Wrocław. Dolnośląska opozycja 
młodzieżowa lat osiemdziesiątych. Perspektywa metropolii a perspektywa terenu s. 85-134; Sychowicz Krzysztof: Środowiska młodzieżowe województw białostockiego i suwalskiego wobec wydarzeń politycznych w Polsce w latach 1983-1989; Tekieli Robert: Ruch alternatywny lat osiemdziesiątych oczami świadka s. 155-164; Pączek Mirosław: Subkultury młodzieżowe a fenomen trzeciego obiegu kultury w ostatniej dekadzie PRL s. 165-182; Idzikowska-Czubaj Anna: Po co wolność? Rock jako forma młodzieżowej kontestacji systemu w PRL lat osiemdziesiątych - historia i legenda s. 183-194; Głowacki Bartosz: Punkrockowe fanziny jako przykład alternatywnej kultury młodzieżowej w schyłkowym PRL s. 195-223; Czyżewska-Poncyliusz Weronika: Czas kultury - czas działania. Kontrkulturowy rodowód pewnego pokolenia społeczników s. 225-242; Pelka Anna: Moda drugiego obiegu. Niezależna działalność łódzkich projektantów mody w latach osiemdziesiątych s. 243-251; Brzechczyn Krzysztof: Myśl polityczna młodzieżowego ruchu anarchistycznego w Polsce w latach osiemdziesiątych XX w. s. 255-265; Kasprzycki Remigiusz: Portret anarchisty-antykomunisty. Aktywność polityczna Marka Kurzyńca w latach 1988-1990 s. 267-276; Tomasiewicz Jarosław: „Młodzi” przeciwko „,starym”. Koncepcje ideowo-polityczne i działalność środowisk młodonacjonalistycznych w PRL lat osiemdziesiątych s. 277-301; Wołk Grzegorz: Ostatnie pokolenie piłsudczyków? Młodzieżowe organizacje afiliowane przy warszawskiej Konfederacji Polski Niepodległej s. 303-333; Krupecka Małgorzata: Formacyjny wpływ duszpasterstw warszawskich na antysystemowe postawy młodzieży w latach osiemdziesiątych. Rekonesans badawczy s. 335-364; Wierzbicki Marek: Między władzą a opozycją. Ruchy społeczne młodzieży w ostatniej dekadzie PRL - rozważania wstępne s. 367-398; Gałaszewska-Chilczuk Dorota: Wszystko zaczęło się w „Mikrusie”. W poszukiwaniu źródeł antysystemowych postaw i zachowań, czyli geneza Niezależnego Zrzeszenia Studentów na Politechnice Warszawskiej s. 399-405; Majchrzak Grzegorz: „Gadałą” w system. Audycje radiowe podziemia młodzieżowego w Warszawie (1982-1989) s. 407-422; Baran Adam F.: „Z KGB na karku”. Rola Związku Harcerstwa Rzeczypospolitej w odrodzeniu i tworzeniu harcerskich środowisk i organizacji wśród Polaków w zachodnich republikach ZSRR oraz jego „służba na pograniczu kultur” (1989-1991) s. 423-429; Kowal Paweł: Na straconych pozycjach. Ostatni bój PZPR o dusze młodych w latach 1986-1989 s. 431-451.

\section{Okres 1989-2016}

298. [DWADZIEŚCIA pięć] XXV lat nauczania religii w polskiej szkole. Między nadzieją a rzeczywistością. Red. Marian Zając. Lublin 2015 Natan ss. 366, il.

Z treści: Zając M.: Wprowadzenie s. 9-10; Chałupniak Radosław: Szkolne nauczanie religii w Polsce w kontekście europejskim s. 13-35; Tomasik Piotr: Polskie dokumenty katechetyczne dwudziestopięciolecia 1990-2015 s. 37-65; Panuś Tadeusz: Katecheza w zwierciadle mediów s. 67-89; Barciński Zbigniew: 25 lat katechezy w szkole - próba bilansu s. 91-104; Kloch Józef: Katecheza z perspektywy rzecznika Konferencji Episkopatu Polski s. 105-112; Słotwińska Helena: Idealny katecheta na współczesne czasy s. 125-138; Kiciński Andrzej: Rozwój katechezy specjalnej s. 139-150; Wrońska Halina: Komplementarność nauczania religii w szkole i katechezy parafialnej s. 151-162; Goliszek Piotr: Zakres nauczania katechezy w latach 1990-2015 w archidiecezji lubelskiej s. 163-190; Łabendowicz Stanisław: Wychowanie dzieci i młodzieży w katechezie szkolnej s. 191-204; Kulpaczyński Stanisław: 25 opinii katechetów o 25 latach katechezy w Polsce s. 205-227; Święs Kazimierz: Szkolne nauczanie religii w odbiorze społecznym s. 229-240.

299. GODZWON Zofia: Opinie profesorów tytularnych uczelni krakowskich o kształceniu młodej kadry naukowej jako wyraz współczesnej myśli pedagogicznej środowiska akademickiego. Polska Myśl Pedagogiczna. Nr 2: 2016 s. 379-390.

Na podst. badań w $2012 \mathrm{r}$.

300. GUMUŁA Teresa: Konferencja naukowa „Historia wychowania na przełomie XX i XXI wieku. Kontynuacje i nowe wyzwania”, Kielce 7-8 marca 2016 r. Biuletyn Historii Wychowania. [Nr] 34: 2016 s. 225-227.

301. IWASZKO Kazimierz: Współpraca oświaty gdyńskiej z polskimi szkołami na Litwie. Zeszyty Gdyńskie. Nr 11: 2016 s. 189-196. 
302. JAWORSKA-MATYS Dorota, Alieva Khedi: Edukacja dzieci imigrantów w Gdańsku od interwencji do miejskiej polityki społecznej. Studia Pedagogiczne. T. 69: 2016 s. 251-266.

303. KAMIŃSKA Wioletta: Poziom wykształcenia zasobów wiejskiej siły roboczej w Polsce. Analiza przestrzenna. Studia Obszarów Wiejskich. T. 41: 2016 s. 9-30.

304. KHANG Nguyen Duy, Tuyet Van Phan Thi: Vietnamese immigration in Poland. Issues of education and integration for children. Problemy Wczesnej Edukacji. R. 122016 nr 4 s. 127-144.

305. KRAJEWSKA Anna: Współdziałanie dydaktyczne nauczycieli akademickich i studentów a jakość kształcenia na przykładzie studiów pedagogicznych. Białystok 2016 Wydaw. Uniwersyteckie Trans Humana ss. 433, il.

306. LANGE Pamela: Migracje edukacyjne kobiet do Warszawy w perspektywie biograficznej. Relacje. $2016 \mathrm{nr} 2$ s. 163-175.

Lata 2001-2016.

307. ŁUKASIK-GĘBSKA Sylwia: Koncepcje edukacji w programach wyborczych wybranych polskich partii politycznych z 2011 i 2015 roku. Spoleczeństwo, Edukacja, Język. T. 4: 2016 s. $53-62$.

308. MALICKI Krzysztof, Piróg Krzysztof: Postawy młodzieży ponadgimnazjalnej wobec przeszłości i historii Polski XX wieku. Warszawa 2016 Wydaw. IFiS PAN ss. 274, il.

309. NAUCZANIE religii w szkole w latach 1990-2015 wobec zadań katechezy. Red. Aneta Rayzacher-Majewska, Rafał Bednarczyk. Warszawa 2016 Wydaw. Uniw. Kard. Stefana Wyszyńskiego ss. 215, il.

Dane statystyczne.

310. OSEWSKA Elżbieta, Stala Józef: Die katholische Schule zu Beginn des XXI. Jahrhunderts am Beispiel Polens und England. Warszawa 2015 Wydaw. Uniw. Kardynała Stefana Wyszyńskiego ss. 200.

311. PRZYBYLSKI Błażej: Studenci Pedagogiki Akademii Pedagogiki Specjalnej w Warszawie i ich orientacje edukacyjne. Prezentacja wyników badań własnych. Kultura i Edukacja. 2016 nr 3 s. $192-209$.

312. PRZYBYSZ Kinga: Relacje państwo-Kościół katolicki w dyskursie „Gościa Niedzielnego”. Casus edukacji publicznej. Środkowoeuropejskie Studia Polityczne. [T.] 3: 2016 s. 121-133.

Lata $2005-2015$.

313. SPOREK Paweł: Przestrzeń aksjologiczna w wybranych podręcznikach gimnazjalnych do kształcenia kulturowego (1999-2005). Kraków 2016 Wydaw. Nauk. Uniw. Pedagog. ss. 319, nlb. 1. Uniw. Pedagog. im. Komisji Edukacji Nar. (Prace Monograficzne; 759).

314. STACHOWICZ Jacek: Patologie organizacyjne w szkolnictwie wyższym w Polsce w latach 1990-2007. Toruń 2015 Adam Marszałek ss. 366, il.

315. ŚWIĘTEK Agnieszka: Edukacja uczniów romskich w województwie małopolskim. Kraków 2016 Wydaw. Nauk. Uniw. Pedagog. ss. 153, nlb. 1, il. Uniw. Pedagog. im. Komisji Edukacji Nar. w Krakowie. (Prace Monograficzne; 765).

Lata 1989-2013.

316. TYTKO Marek Mariusz: O kształceniu studentów niepełnosprawnych w uniwersytecie. Polska Myśl Pedagogiczna. Nr 2: 2016 s. 359-378.

XXI w. 
317. ZADROŻNA Hanna: Szkolnictwo mniejszości ukraińskiej w Polsce i polskiej mniejszości na Ukrainie. Przegląd Środkowo-Wschodni. T. 1: 2016 s. 215-244.

Od 1989 r.

318. ZDUNEK Ewa: Nauczanie religii kościoła polskokatolickiego w szkołach publicznych w Polsce. Przeglad Prawa Wyznaniowego. T. 8: 2016 s. 129-143.

Po 1989 r.

\section{Oświata polonijna}

319. BARAN Adam F.: Z tymi co zostali... Harcerskie relacje Warszawa-Londyn (1945-1990). Warszawa 2016 Inst. Nauk Polit. PAN ss. 179, nlb. 2.

ZHP poza granicami kraju.

320. CHWASTYK-KOWALCZYK Jolanta: Wizerunek o. Józefa Jarzębowskiego (1897-1964) - pedagoga, żołnierza, księdza, uczonego, poety, kreowany na łamach polskich czasopism emigracyjnych. Lubelski Rocznik Pedagogiczny. Vol. 35: 2016 no 4 s. 121-140.

321. CO DALEJ? Instruktorzy harcerscy o Polsce, harcerstwie i młodzieży na łamach pism władz harcerskich na uchodźstwie (1940-1946). Zespół red. Wiesław Kukla, Marian Miszczuk. Warszawa 2016 Tomiko ss. 114. (Dzieje Harcerskich Wydawnictw Polonijnych i Emigracyjnych; t. 9).

322. OLECHOWSKI Piotr: „Usprawnić pracę wychowawczą...”. Obraz polskojęzycznego szkolnictwa w sowieckim Lwowie na łamach „Czerwonego Sztandaru” w latach 1948-1950. Glaukopis. Nr 33: 2016 s. 116-138.

323. [OLİJNIK Marîa Ìvanìvna, Mačins'ka Nataliâ] Olijnik Mariya, Machynska Nataliya: Formation and development of preschool education and teacher training in the Bukovyna (the 19th and the beginning of the 21 st century). Studia Pedagogiczne. T. 26: 2015 s. 23-54.

324. SADOWSKA Edyta: Idee wychowania państwowego II Rzeczypospolitej w wychowaniu fizycznym junaków i ochotników na Bliskim i Środkowym Wschodzie (1942-1947). Studia i Prace Pedagogiczne. $\mathrm{Nr} 2: 2015$ s. 231-249.

325. SZOSKA Maria: Z dziejów jednej szkoły. Cz. 1. Almanach Nowotarski. Nr 20: 2016 s. $378-391$.

Szkoła Młodszych Ochotniczek w Nazarecie (1942-1943). 


\section{DZIEJE SZKÓŁ RÓŻNYCH STOPNI}

\section{Szkoły podstawowe i zakłady wychowawcze}

326. BAZAK Agata Łucja: Szkoła początkowa w Staszowie do drugiej połowy XVIII wieku. Sandomierz 2016 Armoryka ss. 114.

Od XVI w.

327. JURZYSTA Marcin: Zespół Szkół w Czudcu - tradycja i nowoczesność, sukcesy i problemy. Prace Naukowe Akademii im. Jana Dlugosza. Pedagogika. T. 25: 2015 nr 1 s. 683-691.

Od $1944 \mathrm{r}$.

328. KOŁODZIEJCZAK Ryszard: Szkoła podstawowa w Michałowie w latach 1934-1945. Parantele. Nr 1: 2016 s. 51-56.

329. KOŚCIELNIAK Zofia, Pajka Krystyna: Glisne. Historia, oświata, tradycje. Glisne 2016 Szkoła Podst. ss. nlb. 1, 129, il.

Szkoła Podstawowa im. św. Floriana, XIX-XXI w.

330. KRONIKA Szkoły Podstawowej nr 2 w Wiśle. Cz. 2. Oprac. Danuta Szczypka. Rocznik Wiślański. T. 8: 2016 s. 77-97.

Lata 1919-1939.

331. NASZE wspomnienia. 1966-2016. Red. Maciej Samolej, Jagoda Smejda, Kazimiera Sankowska. Łódź 2016 Archidiec. Wydaw. Łódzkie ss. 119, nlb. 1, il.

Państwowy Zakład Wychowawczy dla Dziewcząt w Łodzi.

332. NOWAK Jan: Nasza szkoła. 150-lecie szkoły w Zagórniku 1866-2016. Kraków 2016 Wydaw. Inst. Teol. Księży Misjonarzy ss. 93, nlb. 2, il.

333. RODAK Władysław: Stuletnia Szkoła Podstawowa w Okrajniku (1914-2014). Pokoleniowe troski i nadzieje. Gronie. Nr 16: 2016 s. 49-64.

334. SŁONECZNA historia. Rumia-Reda 2016 Tomasz Modzelewski ss. 89, il.

„Słoneczna Jedynka” Przedszkole nr 1 w Rumi - od 1944.

335. SŁUCHALI dzwonów z dwóch kościołów. Kroniki z Biskupic koło Olesna - katolickiej szkoły i ewangelickiej parafii. Oprac., wstępem i przypisami opatrzył Bernard Joszko. Opole 2016 Red. Wydawnictw Wydz. Teol. Uniw. Opolskiego; Wydaw. i Drukarnia Świętego Krzyża ss. 550, nlb. 2, tabl. 24, il.

M.in. Kronika szkoły katolickiej z 1. 1866-1945.

336. SOSNOWSKA Joanna: Inicjatywy opiekuńcze i oświatowo-wychowawcze łódzkiej społeczności żydowskiej w latach I wojny światowej - Przytulisko dla Dzieci Wyznania Mojżeszowego. Biuletyn Historii Wychowania. [Nr] 34: 2016 s. 21-35.

337. SZKOŁA Podstawowa nr 1 im. Władysława Jagiełly w Ptaszkowej (1839-2015). Praca zbiorowa. Pod red. Henryka Siedlarza. Ptaszkowa 2016 Wydaw. eBooki.com.pl ss. 173, il.

338. SZYPULSKA Barbara: Szkoła Podstawowa w Korycinie do lat 90. XX wieku. Zarys historyczny. Korycin 2016 Zespół Szkół ss. 132. 
339. ŚLĘCZKA Ryszard: Nauczyciele Szkoły Ćwiczeń krakowskiego Pedagogium. Studia Paedagogica Ignatiana. Vol. 19: 2016 [nr] 2 s. 211-226.

W $1933 \mathrm{r}$.

340. ZABORNY Piotr: Opowieść o białowieskich „puszczakach” z Naszej Klasy. Warszawa-Białowieża 2016 Dux; nakł. własnym bohaterów książki ss. 87, il.

Dzieje szkoły podstawowej w Białowieży, XX w.

341. ZARYS monografii Szkoły Podstawowej w Niedrzwicy Dużej (w 100-lecie szkolnictwa w gminie Niedrzwica 1915-2015). Praca zbior. pod red. Magdaleny Kosidło. Niedrzwica Duża 2016 Tow. Przyj. Ziemi Niedrzwickiej ss. 100, il. (Zeszyty Niedrzwickie).

\section{Szkoły ponadpodstawowe ogólnokształcące}

342. BUCZEK Katarzyna: Zbiory dydaktyczne Gimnazjum i Liceum Wołyńskiego w Krzemieńcu (1805-1833). Warszawa 2016 Wydaw. Uniw. Warszawskiego ss. 267, nlb. 3, tabl. 12, il.

343. CEKLARZ Katarzyna: Nowotarskie gimnazjum oraz Nowy Targ w latach 1907-1913 we wspomnieniach dr. Sebastiana Flizaka. Almanach Nowotarski. Nr 20: 2016 s. 249-261.

344. CHMIELEWSKA Gizela: Gimnazjum Kresowe w Bydgoszczy. Kronika Bydgoska. T. 37: 2016 s. $121-138$.

Lata 1920-1921.

345. CZWOŁEK Arkadiusz, Wiśniewski Jan: Szkoła niepokornych Pomorzaków! Likwidacja Niższego Seminarium Duchownego (Collegium Marianum) w Pelplinie przez władze komunistyczne w świetle materiałów archiwalnych (1950-1961). Pelplin 2016 Bernardinum ss. 227, nlb. 1, il.

346. DANOWSKA Ewa: Nowatorski program nauczania i wychowania w Gimnazjum Wołyńskim, późniejszym Liceum w Krzemieńcu (1805-1831). Studia Paedagogica Ignatiana. Vol. 19: 2016 [nr] 3 s. 79-99.

347. DĘBCZAK Barbara, Gawlik Marek: Historia chorzowskiego „Chemika”. Zarys monograficzny Zespołu Szkół Technicznych i Ogólnokształcących nr 4 im. Jędrzeja Śniadeckiego, 1945-2015. Rozdz. XIV Joanna Krzesiewicz-Rowińska. Chorzów 2016 Zespół Szkół Techn. i Ogólnokształcących nr 4 im. Jędrzeja Śniadeckiego ss. 177, nlb. 1, il.

348. GALERIA portretów I Liceum Ogólnokształcącego w Ostrowie Wielkopolskim. Pod red. Marka Lewickiego; aut. tekstów Jarosław Biernaczyk [i in.]. Wyd. 2. poszerz. Ostrów Wielkopolski 2015 Stow. Wychowanków „Alma Mater Ostroviensis” I LO im. ks. Jana Kompałły i Wojciecha Lipskiego; I LO im. ks. Jana Kompałły i Wojciecha Lipskiego; Wydaw. Galeria. Pow. Galeria Sztuki Współczesnej ss. 118, il.

Wyd. 1. 2012.

349. GŁUCHOWSKA Anna, Głuchowski Jan: Nasze lata w liceum sochaczewskim $1953-$ -1957. Toruń 2016 Wyższa Szkoła Bankowa ss. 174, il.

350. GNAT-WIETESKA Zbigniew: Liceum Ogólnokształcące w Garwolinie (1961-1989). Zeszyty Historyczne Ziemi Garwolińskiej. Nr 21: 2016 s. 128-141. 
351. GRZYBOWSKI Michał Marian: Dziedzictwo i tradycje najstarszej szkoły płockiej. Płock-Sierpc 2014 P.P.-H. Drukarnia ss. 66, il.

Liceum Ogólnokształcące im. Marszałka Stanisława Małachowskiego.

352. KAPŁON Zenon: $Z$ badań nad posługą katechetyczną dla młodzieży w szkole publicznej na przykładzie Liceum Ogólnokształcącego - Zespołu Szkół Ponadgimnazjalnych w Dębnie w latach 1945-2015. Colloquia Theologica Ottoniana. 2016 [nr] 1 s. 57-67.

353. KĘPKOWSKA Bogusława Bożena: 95 lat działalności Zespołu Szkół Ogólnokształcących i Sportowych w Pruszkowie. Pruszków 2016 Książnica Pruszkowska im. Henryka Sienkiewicza ss. 663 , il.

354. KRÓLIKOWSKA Anna: Chyrowski Zakład Naukowo-Wychowawczy w „Sprawozdaniach". Studia Paedagogica Ignatiana. Vol. 19: 2016 [nr] 2 s. 105-121.

W 1. 1886-1939.

355. KUBIK Władysław: Szkoła średnia w Solcu nad Wisłą w realizacji polityki oświatowej państwa i egzystencjalnych aspiracji młodzieży 1866-2016. Opowieść historyczna. Solec-Lublin 2016 Stow. Przyj. Solca; Drukarnia Multipress, G. Wodecki, D. Wodecka ss. 280, il.

356. MICHNA Radosław: Dyscyplina i karność w XIX-wiecznym Królewskim Gimnazjum w Bydgoszczy. Kronika Bydgoska. T. 37: 2016 s. 45-62.

357. MIECZYŃSKI Grzegorz: Fabianiacy. Uczniowie pensji męskiej Feliksa Fabianiego [1838-1904]. Radomsko 2016 PTH. Oddz. ss. 127, nlb. 1, il. (Radomszczańska Biblioteczka Regionalna; 12).

XIX-XX w.

358. MUELLER Rafał: Sport szkolny w Sulęcinie w latach 1970-2015 na przykładzie Liceum Ogólnokształcącego. [W:] Kultura fizyczna w Polsce Ludowej i w Trzeciej Rzeczypospolitej. Pod red. Tomasza Jurka, Renaty Urban. Gorzów Wielkopolski 2016 s. 261-273.

359. OLSZAK Alicja: Gimnazjum Żeńskie im. Heleny Czarnieckiej w Lublinie (1938/1939-1939/1940) - we wspomnieniach mojej mamy Genowefy Olszak. Studia i Prace Pedagogiczne. Nr 2: 2015 s. 225-238.

360. PARZYŃSKI Wojciech: O liceum w Wilanowie i jego twórcy słów kilka. Warszawa 2016 Agencja ATM ss. 422, nlb. 40, il.

XXXVIII LO im. Stanisława Kostki Potockiego, Jan Kazimierczak (1910-2011).

361. PRO MEMORIA. Osoby zasłużone dla Liceum Ogólnokształcącego im. ks. Stanisława Konarskiego w Oświęcimiu. Pod red. Katarzyny Musiał. Wadowice-Oświęcim 2016 Drukarnia i Wydaw. Grafikon; na zlec. Tow. Przyj. LO im. Stanisława Konarskiego ss. 96, il.

Lata 1861-2016; wspomnienia.

362. STAWOWCZYK Katarzyna: Żywiecki „Ogólniak” w pejzażu kulturalnym miasta. Ciekawostki z historii Liceum Ogólnokształcącego im. M. Kopernika w Żywcu. Cz. 1. Gronie. Nr 16: 2016 s. $163-186$.

Od lat 90. XIX do 30. XX w.

363. ŚWIDER Marek, Urlińska Maria Marta: Prywatne Gimnazjum Sanatoryjne Męskie dr. Jana Wieczorkowskiego w Rabce (1924-1939). Studia Paedagogica Ignatiana. Vol. 19: 2016 [nr] 2 s. 227-249. 
364. WADOWICKIE Gimnazjum oraz Liceum - znane i nieznane. 150-lecie powstania Gimnazjum w Wadowicach 1866-2016. Red. nauk. Kazimierz Karolczak, Jacek Popiel, Konrad Meus. Wadowice-Nowy Sącz 2016 Stow. Absolwentów LO im. Marcina Wadowity w Wadowicach; Wydaw. i Drukarnia Nova Sandec ss. 352, tabl. 8, il.

Treść: Karolczak K., Popiel J.: Wstęp s. 5-11; Graff Tomasz: Patron I Liceum Ogólnokształcącego w Wadowicach: Magnificus Martinus Campius Vadovius (ok. 1567-1641), dziekan Wydziału Teologicznego i wicekanclerz Akademii Krakowskiej s. 15-37; Sroka Łukasz Tomasz: Młodzież żydowska w wadowickim Gimnazjum s. 39-53; Chrząszcz Czesław: Księża katecheci c.k. Gimnazjum w Wadowicach (1866-1918) s. 55-85; Janusz Maksymilian: Opat Teodor Józef Magiera O. Cist. z Andrychowa - jako absolwent c.k. Gimnazjum w Wadowicach w latach 1874-1881 s. 87-99; Praśkiewicz Szczepan T.: Wybitniejsi absolwenci wadowickiego Gimnazjum z lat 1892-1915 w Zakonie Karmelitów Bosych s. 101-120; Meus Konrad: Bursa gimnazjalna im. Stefana Batorego w Wadowicach - historia znana i nieznana s. 121-151; Nowakowski Andrzej: Wychowanie fizyczne i sport w wadowickim Gimnazjum w czasach Drugiej Rzeczypospolitej s. 153-173; Ratajczak Tomasz: „Lutnia Szkolna” jako przykład pisma literacko-artystycznego w dwudziestoleciu międzywojennym s. 175-189; Wądolny-Tatar Katarzyna: Wadowickie dzieciństwo i beskidzki pejzaż (ze Skawą) w poezji Janiny Brzostowskiej [1897-1986] s. 191-203; Brynkus Józef: Gimnazjum w Wadowicach po reformie systemu oświaty Janusza Jędrzejewicza (do 1939 roku). Zarys problematyki s. 205-220; Witkowski Marcin: Pamiętnik zbiorowy - wojenne wypracowania uczniów wadowickiego Gimnazjum i Liceum spisane w październiku 1939 roku s. 221-246; Koźbiał Krzysztof: Wadowickie Gimnazjum i Liceum im. M. Wadowity w nowej rzeczywistości społeczno-politycznej lat 1945-1948. Przyczynek do dziejów s. 247-268; Hudzik Paweł: Archiwum Liceum Ogólnokształcącego im. Marcina Wadowity w Wadowicach s. 269-280; Staniek Edward: Wychowanie i samowychowanie według św. Józefa Bilczewskiego s. 283-297; Guzdek Józef: Św. Jan Paweł II - sól ziemi i światło dla świata s. 299-312; Bibliografia zbiorcza s. 313-336.

365. ŻYWIECKI „ogólniak” w pejzażu kulturalnym miasta. Ciekawostki z historii Liceum Ogólnokształcącego im. M. Kopernika w Żywcu. cz. 1. [Aut.] Katarzyna Stawowczyk [i in.]. Gronie. Nr 16: 2016 s. 163-186.

\section{Szkoły zawodowe}

366. DOMAGAŁA Jarosław: Państwowa Szkoła Muzyczna I i II st. im. Karola Kurpińskiego w Kutnie 1946-2016. Kutno 2016 Kutnowskie Stow. Promocji Muzyki ss. 336, il.

367. GOŁDYN Piotr: Fragment dziejów Publicznej Dokształcającej Szkoły Zawodowej w Łucku w świetle zachowanej korespondencji. Rozprawy z Dziejów Oświaty. T. 53: 2016 s. 45-59.

Lata 1934-1936.

368. INNA. Szkoła jakich już nie ma... Wspomnienia nauczycieli i absolwentów Zespołu Szkół Pedagogicznych i Technicznych im. Komisji Edukacji Narodowej przy ulicy Krzywej w Lublinie. Pod red. Alicji Omiotek. Lublin 2016 Polihymnia ss. 229, tabl. 42, il.

Lata 1962-1993.

369. JUBILEUSZ 70 lat Zespołu Szkół Muzycznych w Gdańsku-Wrzeszczu. Wspomnienia absolwentów Szkoły Muzycznej II stopnia im. Fryderyka Chopina. Red. nacz. Robert Kaczorowski. Pelplin 2016 Bernardinum ss. 167, il.

370. KACZMARCZYK Jan: Szkolnictwo zawodowe w Hucie „Częstochowa”. Zarys problemu. Ziemia Częstochowska. T. 42: 2016 s. 29-34.

371. KUCIAPIŃSKI Marek: Rozwój społecznego szkolnictwa muzycznego w Piotrkowie Trybunalskim po II wojnie światowej do powstania Państwowej Szkoły Muzycznej I stopnia w 1966 r. Rocznik Polsko-Ukraiński. T. 18: 2016 s. 95-117. 
372. KULBACKA Anna: Zanim powstały technika leśne... Ośrodek szkoleniowy w Białowieży na tle szkolnictwa zawodowego leśnego w Polsce w latach 1945-1951. Gołuchów 2016 Ośr. Kultury Leśnej ss. 163, il.

373. LIZUT Grażyna: Wolontariat szkolny Vetter w roku jubileuszów. Monografia 150-lecia Zespołu Szkół Ekonomicznych im. Augusta Juliusza Vetterów. 20-lecie wolontariatu. Lublin 2016 Polihymnia ss. 108 , il.

W Lublinie.

374. OBŁĄKANI teatrem... 50 lat Państwowego Policealnego Studium Wokalno-Aktorskiego im. Danuty Baduszkowej w Gdyni. Praca zbiorowa. Pod red. Jacka Westera. Gdynia 2016 Państ. Policealne Studium Wokalno-Aktorskie im. Danuty Baduszkowej ss. 160, il. Państ. Policealne Studium Wokalno-Aktorskie im. Danuty Baduszkowej w Gdyni.

375. PODGÓRSKA Barbara, Podgórski Adam: Rogozinieckie reminiscencje 1965-1970. Ruda Śląska 2016 Rudzkie Tow. Przyj. Drzew OPP ss. 141, nlb. 1, il.

Technikum Leśne w Rogozińcu.

376. ROMEYKO-HURKO Marcin: Szkoła Dekoracyjno-Artystyczna Chalus i Dunin. Zapomniany rozdział życia artystycznego Warszawy. Sztuka i Dokumentacja. Nr 15: 2016 s. 27-38.

Zał. w 1903 r. przez Cecylię Chalus i Antoninę Dunin-Sulgostowską.

\section{Zakłady kształcenia nauczycieli (z wyjątkiem szkół wyższych)}

377. CHMIELEWSKI Witold: Państwowe Seminarium Nauczycielskie Żeńskie w Piotrkowie w pierwszych latach działalności (1916-1919). W stulecie powstania. Studia Paedagogica Ignatiana. Vol. 19: 2016 [nr] 3 s. 201-223.

378. DOROSZEWSKI Jerzy: Pochodzenie społeczne uczniów seminariów nauczycielskich w Polsce w latach 1918-1937. Przegląd Historyczno-Oświatowy. R. 59: 2016 nr 1/2 s. 88-102.

379. FELINIAK Aleksandra, Leżańska Wiesława: Organizacyjne formy kształcenia nauczycieli przedszkoli w Łodzi w latach 1945-1989. Przeglą Historyczno-Oświatowy. R. 59: $2016 \mathrm{nr}$ 3/4 s. $122-143$.

380. KRÓLIKOWSKA Anna: Jezuickie seminaria nauczycielskie - pierwsze instytucjonalne formy kształcenia nauczycieli w Polsce. Przegląd Historyczno-Oświatowy. R. 59: $2016 \mathrm{nr}$ 3/4 s. $27-39$.

XVI-XVIII w.

381. PETROV Vladimir: Kształcenie i doskonalenie nauczycieli w systemie studiów dla pracujących w PRL w latach 70. XX wieku. Roczniki Naukowe Szkoły Wychowania Fizycznego i Turystyki w Biatymstoku. 2016 nr 2 s. 59-67.

382. SZULAKIEWICZ Władysława: Kształcenie pedagogiczne w seminariach nauczycielskich Krakowa okresu autonomii galicyjskiej. Studia Paedagogica Ignatiana. Vol. 19: 2016 [nr] 3 s. $143-162$. 


\section{Szkoły wyższe}

\section{Akademia Górniczo-Hutnicza}

383. „NA PODSTAWIE wydanych przez obywatela ministra dyspozycji...”. Akademia Górnicza i Akademia Górniczo-Hutnicza w powojennej rzeczywistości 1945-1989/1990. Dokumenty. [T.] 3. [Oprac.] Anna Siwik, Regina Artymiak, Julian Kwiek. Kraków 2016 Red. Wydawnictw AGH ss. 575, nlb. 3, tabl. 25, il.

T. 1 pt.: „Wysoki Sejm raczy uchwalić...”. Starania o założenie Wyższej Szkoły Górnictwa i Hutnictwa w Krakowie w latach 1861-1914. Dokumenty. Kraków 2013.

T. 2 pt.: „Podejmując rozpoczęte dzieło...”. Akademia Górnicza 1919-1939. Dokumenty. Kraków 2014.

384. WSPOMNIENIA wychowanków Akademii Górniczo-Hutniczej. Kraków 2016 Stow. Wychowanków Akad. Górniczo-Hutniczej im. Stanisława Staszica ss. 132, il.

\section{Akademia Ignatianum}

385. KUBIK Władysław: Początki i rozwój Akademii Ignatianum w Krakowie. Studia Paedagogica Ignatiana. Vol. 17: 2014 s. 15-33.

Od 1989 r.

Akademia Medyczna im. Karola Marcinkowskiego w Poznaniu

386. DECKERT Andrzej: Studium Wychowania Fizycznego i Sportu Akademii Medycznej im. Karola Marcinkowskiego w Poznaniu w latach 1919-2007. Działalność dydaktyczna, naukowa oraz rekreacja i sport akademicki studentów i pracowników. Poznań 2016 Wydaw. Nauk. Uniw. Medycznego im. Karola Marcinkowskiego ss. 132, il. Uniw. Medyczny im. Karola Marcinkowskiego w Poznaniu.

\section{Akademia Muzyczna im. Grażyny i Kiejstuta Bacewiczów w Łodzi}

387. PIETKIEWICZ Mirosław: Z historii uczelni - o kształceniu organistów w latach 1945-2000. Notes Muzyczny. 2016 nr 2 s. 273-290.

\section{Akademia Połocka}

388. KADULSKA Irena: Pracownicy książki w Akademii Połockiej (1812-1820). Acta Univeristatis Lodziensis. Folia Litteraria Polonica. T. 34: 2016 nr 4 s. 257-265. 
Akademia Sztuk Pięknych w Krakowie

389. GRABOWSKA Joanna: Akademia Sztuk Pięknych w Krakowie w czasach Konstantego Laszczki (1899-1935). Wiadomości ASP. [Nr] 75: 2016 s. 54-63.

\section{Akademia Wychowania Fizycznego we Wrocławiu}

390. NAWARA Henryk: Radosna uczelnia. Akademia Wychowania Fizycznego we Wrocławiu 1846-2016 w anegdotach i we wspomnieniach. Wrocław 2016 Wydaw. Akad. Wychowania Fizycznego ss. 291, il.

391. SZUBERT Rafał: Akademia Wychowania Fizycznego we Wrocławiu 1946-2016. Zeszyty Historyczne Akademii Wychowania Fizycznego we Wrocławiu. Wyd. spec. 2016 s. 8-32.

392. SZUBERT R.: Kalendarium AWF we Wrocławiu 2006-2016. Zeszyty Historyczne Akademii Wychowania Fizycznego we Wrocławiu. Wyd. spec. 2016 s. 50-63.

\section{Akademia Zamojska}

393. PELCZAR Roman: Teatr Akademii Zamojskiej w XVII i XVIII wieku. Studia i Prace Pedagogiczne. Nr 2: 2015 s. 157-167.

\section{Częstochowskie Seminarium Duchowne w Krakowie}

394. ZWIĄZEK Jan: Z dziejów Częstochowskiego Seminarium Duchownego w Krakowie (1928-1991). Veritati et Caritati. T. 6: 2016 s. 349-419.

\section{Elbląska Uczelnia Humanistyczno-Ekonomiczna}

395. ELBLĄSKA Uczelnia Humanistyczno-Ekonomiczna 2001-2016. Oprac. zespół w składzie Tomasz Borkowski [i in.]. Elbląg 2016 Elbląska Uczelnia Humanist.-Ekonom. ss. 91, il. 


\section{Katolicki Uniwersytet Lubelski}

396. CENTEK Barbara: „Niech sobie tam piszą...”. Działalność wydawnicza Samorządu Studenckiego Katolickiego Uniwersytetu Lubelskiego w ostatniej dekadzie PRL. Folia Toruniensia. [T.] 16: 2016 s. 9-34.

397. ŚWITKA Jan: Dwadzieścia jeden lat studiów Katolickiego Uniwersytetu Lubelskiego w Tomaszowie Lubelskim (w latach 1995-2016). Rzeszów-Boguchwała 2016 Wydaw. Amelia, Aneta Siewiorek ss. 397, il.

\section{Wydział Zamiejscowy Nauk Prawnych i Ekonomicznych KUL Niepaństwowa Wyższa Szkoła Pedagogiczna w Białymstoku}

398. JAKONIUK Adam: 20 lat od powstania Niepaństwowej Wyższej Szkoły Pedagogicznej w Białymstoku. Zagadnienia Społeczne. 2016 nr 2 s. 263-275.

\section{Politechnika Warszawska}

399. JUBILEUSZ 95-lecia Wydziału Geodezji i Kartografii Politechniki Warszawskiej. Oprac. red. Alicja Sadowska, Ryszard Malarski. Warszawa 2016 Oficyna Wydaw. Politech. Warszawskiej ss. 288 , il.

400. TACY byliśmy. Wspomnienia absolwentów Politechniki Warszawskiej. Praca zbiorowa. Pod red. Wojciecha Nowakowskiego. Warszawa 2015 Stow. Absolwentów i Przyj. Politech. Warszawskiej ss. 260, il.

Lata $1951-2012$.

401. ZARYS historii i osiągnięć Instytutu Automatyki i Robotyki Politechniki Warszawskiej (1957-2015). Oprac. wyd. Ilona Trendal (!), Marcin Stachura. Radom 2016 Wydaw. Nauk. Inst. Technologii Eksploatacji - PIB; na zlec. Fund. Politech. Warszawskiej i Koła Absolwentów Mechaniki Precyzyjnej/Mechatroniki ss. 170, il.

\section{Pomorska Szkoła Wyższa}

402. GĄSIOROWSKI Andrzej, Wika Wiesław: Pomorska Szkoła Wyższa w latach 2001-2016. Starogard Gdański 2016 Pomorska Szkoła Wyższa ss. 103, nlb. 1, tabl. 22.

Starogard Gdański. 


\section{Szkoła Główna Gospodarstwa Wiejskiego}

403. [DWIEŚCIE] 200 lat tradycji Szkoły Głównej Gospodarstwa Wiejskiego. Od Marymontu do Ursynowa 1816-2016. Księga jubileuszowa. T. 1: Historia uczelni. Oprac. red. Jan Kiryjow. Warszawa 2016 Wydaw. SGGW ss. 474, il.

Toż. T. 2: Historia wydziałów. Warszawa 2016 ss. 466, il.

404. STAWICKI Maciej, Wojewódzka-Wiewiórska Agnieszka: Z historii Wydziału Nauk Ekonomicznych. Warszawa 2016 Wydaw. SGGW ss. 101, nlb. 3, il.

405. WYDZIAŁ Rolnictwa i Biologii. W 200-lecie utworzenia Instytutu Agronomicznego w Marymoncie. Red. Jan Łabętowicz, Andrzej Radecki. Warszawa 2016 Wydaw. SGGW ss. 350, il. Szkoła Gł. Gospodarstwa Wiej..

Treść: Cz. 1. Rys historyczny s. 13-32; Cz. 2. Wydział Rolnictwa i Biologii w latach 2003-2016 s. 33-75; Cz. 3. Jednostki organizacyjne Wydziału s. 77-294; Cz. 4. Tytuły i stopnie uzyskane w latach 2006-2015 s. $295-350$.

\section{Szkoła Główna Handlowa}

406. HISTORIA zabytkowego kampusu Szkoły Głównej Handlowej w Warszawie. Red. nauk. Wojciech Morawski. Warszawa 2015 Oficyna Wydawnicza. Szkoła Gł. Handlowa ss. 150, il., mapy.

407. WKŁAD Szkoły Głównej Handlowej w Warszawie w rozwój myśli ekonomicznej. Red. nauk. Ryszard Bartkowiak. Warszawa 2015 Oficyna Wydawnicza. Szkoła Gł. Handlowa ss. 444.

XX-XXI w.

\section{Szkoła Rycerska Kadetów}

408. [CZARTORYSKI Adam Kazimierz]: Prawidła moralne dla Szkoły Rycerskiéy. przez Adama Czartoryskiego w roku 1774 ułożone. Oświęcim 2016 Napoleon V ss. nlb. 6, XIV, nlb. 4, 77, nlb. 15 , il.

409. KAJETY Korpusu Kadetów Szkoły Rycerskiej. Red. nauk. Elżbieta Wichrowska, Agata Wdowik. Warszawa 2016 Uniw. Warszawski. Wydz. Polonistyki ss. 420, il.

Lata $1765-1794$.

410. SZKOŁA Rycerska Kadetów Jego Królewskiej Mości i Rzeczypospolitej. Red. nauk. Waldemar Bednaruk, Kamil Jaszczuk. Lublin 2016 TN KUL Jana Pawła II ss. 282, nlb. 4, il. TN KUL. (Źródła i Monografie; 426).

Z treści: Lewandowska-Malec Izabela: Szkoła Rycerska w Paktach Konwentach. Postanowienia i realizacja s. 13-21; Bednaruk W.: Narodziny Szkoły Rycerskiej s. 23-33; Zakrzewski Andrzej: Szkoła Rycerska między Koroną a Litwą s, 35-42; Białowąs Katarzyna: Organizacyjno-programowy model kształcenia kadetów w Szkole Rycerskiej s. 45-51; Jaszczuk K.: Program i organizacja szkolenia wojskowego w Szkole Rycerskiej s. 53-59; Łusiak Piotr: Finansowanie Akademii Szlacheckiego Korpusu Jego Królewskiej Mości i Rzeczypospolitej w świetle konstytucji sejmowych s. 61-74; Gil Andrzej: Komendant Szkoły Rycerskiej książę Adam 
Kazimierz Czartoryski. Uwagi na tle epoki s. 75-81; Łopatecki Karol: działalność naukowa Antoniego Leopolda Oelsnitza prowadzona w Szkole Rycerskiej s. 83-105; Czyża Sandra: Tadeusz Kościuszko jako wzorowy absolwent Szkoły Rycerskiej s. 107-122; Łopuszyński Krzysztof: Julian Ursyn Niemcewicz jako absolwent Szkoły Rycerskiej s. 123-129; Jaszczuk K., Łusiak K.: Obraz Szkoły Rycerskiej w oczach kadeta Seweryna Bukara s. 131-136; Bogalski Artur: Kilka słów o losach wychowanków Szkoły Rycerskiej związanych z departamentem siedleckim i województwem podlaskim s. 137-160; Lubaszewski Zbigniew: Tadeusz Kościuszko w dziejach ziemi chełmskiej. Związki i miejsca pamięci s. 161-176; Dyjakowska Marzena: Reforma studiów prawniczych w okresie stanisławowskim s. 179-200; Gardziński Zygmunt, Oskierko Marcin: Chełmskie Kolegium Pijarów w dobie działalności Komisji Edukacji Narodowej s. 201-224; Lasek-Surowiec Iwona: Ekonomiczne aspekty funkcjonowania szkół pijarskich na Lubelszczyźnie w XVIII wieku s. 225-241; Bibliografia s. $277-282$.

\section{Uniwersytet Ekonomiczny w Katowicach}

411. CZECH Alojzy: Rektorat i budynek „A”. Pierwsze własne obiekty uczelni. Katowice 2016 Wydaw. Uniw. Ekonom. ss. 71, nlb. 1, il.

\section{Uniwersytet im. Adama Mickiewicza}

412. INSTYTUT Historii Uniwersytetu im. Adama Mickiewicza w Poznaniu w latach 20062016. Red. Józef Dobosz, Danuta Konieczka-Śliwińska, Przemysław Matusik. Poznań 2016 Inst. Historii UAM ss. 285, nlb. 2, il.

Treść: Dobosz J.: Wstęp s. 5-6; Matusik P.: Aktywność naukowa w Instytucie Historii UAM w latach 2006-2016. Próba podsumowania s. 7-38; Konieczka-Śliwińska D.: Działalność dydaktyczna Instytutu Historii s latach 2006-2016 s. 39-136; Michalski Maciej: Instytut Historii UAM w Poznaniu w Collegium Historicum na Morasku s. 137-164; Szylin Bogusława: Od Biblioteki Seminarium Historycznego do Biblioteki Wydziału Historycznego s. 165-172; Paszkiewicz Jędrzej: Współpraca Instytutu Historii ze środowiskiem społecznogospodarczym s. 173-186; Kraszewski Igor: Historia Studenckiego Koła Naukowego Historyków im. Gerarda Labudy przy Instytucie Historii UAM. lata 2006-2016 s. 187-248; Spis pracowników. Zestawiła Aleksandra Jagodzińska s. 249-354; Wykaz absolwentów 2006-2016. Zestawiła A. Jagodzińska s. 255-280; Książki opublikowane w Wydawnictwie Instytutu Historii UAM w latach 2006-2016. Zestawiła Mariola Mariańczyk s. $281-285$.

413. KOBELSKA Adela: Miasto, uniwersytet, literaturoznawstwo. Poznań lat dwudziestych i trzydziestych XX wieku jako przestrzeń działania członków Koła Polonistów. Warszawa 2016 Wydawnictwa Uniw. Warszawskiego ss. 218, tabl. k. 1, il.

414. STACJE naukowe Uniwersytetu im. Adama Mickiewicza w Poznaniu. Praca zbiorowa. Pod red. Andrzeja Kostrzewskiego. Poznań 2016 Wydaw. Nauk. UAM ss. 199, il. UAM w Poznaniu.

Lata $1971-2016$.

415. JAKŚ-IVANOVSKA Magdalena: Profesorowie Uniwersytetu Poznańskiego 1919-1939. Portret demograficzno-społeczny. Rocznik Dziejów Społecznych i Gospodarczych. T. 76: 2016 s. 341-383. 


\section{Uniwersytet Jagielloński}

416. AUTOPORTRET z gołębnikiem w tle. Profesorowie krakowskiej polonistyki o sobie. Przygot. i red. Marzena Florkowska. Kraków 2016 Wydaw. UJ ss. 58, nlb. 2, il. + 2 dyski optyczne (CD).

Antologia wspomnień 22 profesorów UJ dot. lat 50 i 60.

417. KLINIKI i zakłady teoretyczne. Collegium Medicum Uniwersytetu Jagiellońskiego w krakowskiej dzielnicy Wesoła. Gmachy i ludzie. Pod red. Piotra Franaszka. Kraków 2016 Księg. Akademicka ss. 357, nlb. 3, tabl. 100, il., mapy. (Historia Budynków Uniwersytetu Jagiellońskiego).

Treść: Franaszek P.: Słowo wstępne s. 9-14; Franaszek P.: O początkach szpitalnictwa krakowskiego i historii krakowskiego zespołu szpitalnego w dzielnicy Wesoła s. 15-40; Bęczkowska Urszula: Architektura krakowskich klinik uniwersyteckich i zakładów teoretycznych Wydziału Lekarskiego Uniwersytetu Jagiellońskiego s. 41-158; Wybitni krakowscy medycy z dzielnicy Wesoła s. 159-324; Bibliografia s, 325-335.

418. SONDEL Janusz: Uniwersytet Jagielloński wobec zakonów cystersów i dominikanów. Zeszyty Naukowe - Wyższa Szkoła Turystyki i Ekologii w Suchej Beskidzkiej. R. 5: 2016 nr 2 s. $119-144$.

XV-XVIII w.

419. STINIA Maria: Uniwersytet Jagielloński w latach 1871-1914. Modernizacja procesu nauczania. Kraków 2014 Historia Iagellonica ss. 408, tabl. 8, il. (Studia z Historii XIX Wieku; t. 5).

420. URBANIK Monika, Urbanik Andrzej: Radiologia w kręgu Uniwersytetu Jagiellońskiego (1896-2016). Łąka 2016 Indygo ss. 133, il.

421. ŻUKOWSKI Przemysław Marcin: Wydział Prawa Uniwersytetu Jagiellońskiego w Krakowie w latach 1918-1939. Kraków 2016 Księg. Akademicka ss. 574, tabl. 34, il.

\section{Uniwersytet Kardynała Stefana Wyszyńskiego}

422. KORCZYŃSKI Tomasz M.: Obraz studenta Uniwersytetu Kardynała Stefana Wyszyńskiego w Warszawie. Analiza wyników badań porównawczych z lat 2005-2015. Warszawa 2016 Wydaw. Imago Montage ss. 90, nlb. 2, il. Uniw. Kardynała Stefana Wyszyńskiego. Inst. Socjologii. (Seria Naukowa WIM).

423. MILEWSKI Dariusz: Akta przewodów doktorskich i habilitacyjnych z zakresu nauk historycznych i społecznych Wydziału Teologicznego ATK. Archiwa, Biblioteki i Muzea Kościelne. T. 105: 2016 s. 211-233, sum.

Akta Akademii Teologii Katolickiej w Warszawie w Archiwum Uniwersytetu Kardynała Stefana Wyszyńskiego w Warszawie.

424. [PIĘTNAŚCIE] 15 lat nauk ścisłych na UKSW. Red. Wiesław M. Macek. Warszawa 2016 Wydaw. Nauk. Uniw. Kardynała Stefana Wyszyńskiego ss. 151, il.

Materiały z konferencji, 5-6 listopada 2015 r., Warszawa.

Z treści: Macek W. M.: Słowo wstępne s. 7-10; Bartnicki Roman: Początki Wydziału Matematyczno-Przyrodniczego. Szkoły Nauk Ścisłych s. 13-16; Turzański Marian: Zarys historii Wydziału s. 19-34; Cytowski Jerzy, Seredyński Franciszek: Informatyka na UKSW - krótka i perspektywy s. 97-106. 


\section{Uniwersytet Lwowski}

425. CHROSTEK Mariusz: Złote lata polonistyki lwowskiej (1919-1939). Rzeszów 2016 Wydaw. Uniw. Rzeszowskiego ss. 636, nlb. 1, il.

\section{Uniwersytet Łódzki}

426. KAŹMIERSKA Kaja, Waniek Katarzyna, Zysiak Agata: Opowiedzieć Uniwersytet. Łódź akademicka w biografiach wpisanych w losy Uniwersytetu Łódzkiego. Wyd. 2. uzup. Łódź 2016 Wydaw. UŁ ss. 452, il.

Wyd. 1. 2015.

\section{Uniwersytet Mikołaja Kopernika}

427. INTERAKTYWNY przewodnik po miejscach pamięci Uniwersytetu Mikołaja Kopernika w Toruniu. Pod red. Kingi Majchrzak. Torun 2016 Wydaw. Nauk. UMK ss. 198, nlb. 1, il.

Tablice pamiątkowe, biografie.

\section{Uniwersytet Muzyczny Fryderyka Chopina}

428. DZIADEK Magdalena: Od Szkoły Dramatycznej do Uniwersytetu. Dzieje wyższej uczelni muzycznej w Warszawie 1810-2010. [T. 2:] 1945-2010. Warszawa 2016 Wydaw. Uniw. Muzycznego Fryderyka Chopina ss. 1009, tabl. 2, il.

T. 1. 2011.

429. JANKOWSKA Mirosława, Jankowski Wojciech: Instytut Pedagogiki Muzycznej PWSM/ /AMFC w Warszawie (1974-1992). Warszawa 2016 Wydaw. Uniw. Muzycznego Fryderyka Chopina ss. 434 , il.

\section{Uniwersytet Opolski}

430. [DWADZIEŚCIA] 20 lat Wydziału Historyczno-Pedagogicznego Uniwersytetu Opolskiego. Red. Iwona Alechnowicz-Skrzypek, Edward Nycz. Opole 2016 Wydaw. Uniw. Opolskiego ss. 201, il. Uniw. Opolski. 


\section{Uniwersytet Papieski Jana Pawła II w Krakowie}

431. KAPUŚCIŃSKI Jacek: Stan badań nad dziejami Wyższego Instytutu Teologicznego w Częstochowie. Veritati et Caritati. T. 7: 2016 s. 179-217.

432. STYPUŁKOWSKA Beata: Wykaz wykładowców w Wyższym Instytucie Teologicznym na przestrzeni jego historii oraz w Sekcji Licencjacko-Doktoranckiej. Veritati et Caritati. T. 7: 2016 s. $237-274$.

Lata $1967-2016$.

\section{Uniwersytet Pedagogiczny im. Komisji Edukacji Narodowej}

433. BIEDROŃ Tomasz: Instytut Bezpieczeństwa i Edukacji Obywatelskiej Uniwersytetu Pedagogicznego im. KEN w Krakowie (1966-2015). Annales Universitatis Paedagogicae Cracoviensis. Studia de Securitate et Educatione Civili. [T.] 5: 2015 s. 20-40.

434. WOŹNIAK Monika Anna: Miasto i uczelnia. Uniwersytet Pedagogiczny w Krakowie. Kraków 2016 Uniw. Pedagog. im. Komisji Edukacji Nar. ss. 118, nlb. 10, il.

\section{Uniwersytet Rolniczy w Krakowie}

435. WKŁAD krakowskiego środowiska akademickiego w rozwój studiów rolniczych w Polsce. 125 lat kształcenia rolniczego w Krakowie. Red. nauk. Szymon Sikorskiego. Kraków 2016 Wydaw. Uniw. Rolniczego ss. 152, nlb. 1, il.

Częściowo materiały z konferencji, Kraków, 25 X 2015 r.

Treść: Sady Włodzimierz: Słowo wstępne s. 7-10; Sikorski Sz.: Od redakcji s. 11-12; Wystąpienie JM Rektora Uniwersytetu Jagiellońskiego prof. dr. hab. med. Wojciecha Nowaka s. 15-16; Wystąpienie JM Rektora Uniwersytetu Rolniczego w Krakowie prof. dr. hab. inż. Włodzimierza Sady s. 17-19; Ziejka Franciszek: Hugo Kołłątaj - reformator Akademii Krakowskiej s. 25-34; Gorlach Krzysztof, Nowak Piotr: Studia rolnicze w Uniwersytecie Jagiellońskim (1890-1953) s. 35-43; Gambuś Florian: 125 lat studiów rolniczych w Krakowie. Wyższa Szkoła Rolnicza - Akademia Rolnicza - Uniwersytet Rolniczy s. 45-55; Żmija Janusz: Studia rolnicze w rozwoju gospodarki żywnościowej i obszarów wiejskich s. 57-68; Ziejka F.: Serce Hugona Kołłątaja s. 87-92; Wystawa „Dzieje studiów rolniczych w Krakowie” s. 99-113; Epitafia w budynkach Uniwersytetu Rolniczego s. 115-140; Doktorzy honoris causa Uniwersytetu Rolniczego w Krakowie s. 143-144; Profesorowie Akademii Rolniczej w Krakowie i Uniwersytetu Rolniczego w Krakowie - doktorzy honoris causa innych uczelni s. 145; Glossa s. 147-153.

\section{Uniwersytet Rzeszowski}

436. REKTORSKIE refleksje. Rektorzy Uniwersytetu Rzeszowskiego o Uniwersytecie. Red. Sylwester Czopek. Rzeszów 2016 Wydaw. Uniw. Rzeszowskiego; Oficyna Wydawnicza „Ziemowit" ss. 69 , il. 


\section{Uniwersytet Śląski}

437. JUSZCZYK Stanisław: Jubileusz czterdziestolecia Wydziału Pedagogiki i Psychologii Uniwersytetu Śląskiego (1976-2016). Rodowód - instytucjonalizacja - rozwój - zamierzenia. Chowanna. 2016 t. 1 s. 9-54.

438. NANCKA Grzegorz: Z dziejów nauczania prawa rzymskiego u początków Uniwersytetu Śląskiego w Katowicach. Studia z Dziejów Państwa i Prawa Polskiego. [T.] 19: 2016 s. 345-353.

439. WÓJTOWICZ Marek: Historia kierunku studiów nauki o rodzinie na Wydziale Teologicznym Uniwersytetu Śląskiego w Katowicach. Śląskie Studia Historyczno-Teologiczne. T. 49: 2016 z. 1 s. $226-236$.

W Polsce od r. akad. 1975/76, na Uniwersytecie Śląskim od 2009 r.

\section{Uniwersytet w Białymstoku}

440. UNIWERSYTET w Białymstoku in statu nascendi (1968-1997). Przegląd źródeł. Wybór i oprac. Joanna E. Dąbrowska. Białystok 2015 Wydaw. Uniw. Trans Humana ss. 306, il.

\section{Uniwersytet Warmińsko-Mazurski}

441. OLSZTYN uniwersytecki. Nauka, praktyka, absolwenci. Praca pod red. Andrzeja Farugi i Bolesława Pilarka. Olsztyn 2015 Stow. Absolwentów Uniw. Warmińsko-Mazurskiego; Fund. im. M. Oczapowskiego ss. 781, il.

\section{Uniwersytet Warszawski}

442. BAŽENOVA Anna: Historycy Cesarskiego Uniwersytetu Warszawskiego 1869-1915. Nauka i polityka. Lublin 2016 Inst. Europy Środkowo-Wschodniej ss. 418, il.

443. DZIEJE Uniwersytetu Warszawskiego 1816-1915. Red. nauk. Tomasz Kizwalter. Warszawa 2016 Wydawnictwa Uniw. Warszawskiego ss. 850, il. (Monumenta Universitatis Varsoviensis 1816-2016).

Treść: Tygielski Wojciech: Jubileusz s. 9-11; Kizwalter T., Majewski Piotr M.: Przedmowa s. 12-15; Kizwalter T.: Uniwersytety europejskie w XIX w. s. 17-51; Mycielski Maciej: Uniwersytet Królewski 1816-1831 s. 53-361; Szwarc Andrzej: Warszawa bez uniwersytetu 1831-1857 s. 363-413; Szwarc A.: Akademia Medyko-Chirurgiczna i Szkoła Główna 1857-1969 s. 415-555; Schiller-Walicka Joanna: Cesarski Uniwersytet Warszawski między edukacją a polityką 1869-1917 s. 557-703; Przeciszewska Maria M.: Uniwersytet Cesarski: środowisko naukowe 1869-1917 s. 705-721; Markowski Artur: Uniwersytet Cesarski: uczelnia a społeczeństwo $1869-1917$ s. 723-816;

Bibliografia s. 817-819. 
444. DZIEJE Uniwersytetu Warszawskiego 1915-1945. Red. nauk. Piotr M. Majewski. Warszawa 2016 Wydawnictwa Uniw. Warszawskiego ss. 569, il. (Monumenta Universitatis Varsoviensis 1816-2016).

Treść: Kizwalter Tomasz, Majewski P. M.: Przedmowa s. 9-12; Kizwalter T.: Uniwersytety europejskie w XX wieku s. 15-49; Majewski P. M.: Społeczność akademicka 1915-1939 s. 51-323; Deszczyński Marek P.: Uniwersytet Warszawski w II Rzeczypospolitej s. 325-427; Majewski Piotr:

Uniwersytet czasu wojny s. 429-535; Bibliografia s. 537-546.

445. DZIEJE Uniwersytetu Warszawskiego po 1945 roku. Red. nauk. Piotr M. Majewski. Warszawa 2016 Wydawnictwa Uniw. Warszawskiego ss. 791, il. (Monumenta Universitatis Varsoviensis 1816-2016).

Treść: Kizwalter Tomasz, Majewski P. M.: Przedmowa s. 9-12; Brzostek Błażej: Życie społeczne Uniwersytetu 1945-1989 s. 15-372; Rutkowski Tadeusz P.: Na styku nauki i polityki. Uniwersytet Warszawski w PRL 1944-1989 s. 375-690; Gawin Dariusz: Między Październikiem a Marcem. Uniwersytet Warszawski 1956-1968 s. 693-707 ; Tygielski Wojciech: W państwie demokratycznym i suwerennym s. 709-754; Bibliografia s. $755-761$.

446. GAWKOWSKI Robert: Poczet rektorów Uniwersytetu Warszawskiego. Warszawa 2016 Wydawnictwa Uniw. Warszawskiego ss. 417, il. (Monumenta Universitatis Varsoviensis 1816-2016).

447. [KAZAROVA Nina Akopovna, Lobova Viktoriâ Vladimirovna, Kazarov Sarkis Surenovič] Kazarowa Nina A., Łobowa Wiktorija W., Kazarow Sarkis S.: Historycy Cesarskiego Uniwersytetu Warszawskiego (1869-1915). Czasy i ludzie. Przekł. z jęz. ros. Janina Chodera. Gniezno 2016 Inst. Kultury Europejskiej UAM ss. 193, nlb. 2. Inst. Kultury Europejskiej Uniw. im. Adama Mickiewicza w Poznaniu.

448. KOZŁOWSKI Stefan Karol: Alma Matris Varsoviensis. Studium praehistoricum MCMVII-MCMLXIII. Warszawa 2016 Wydaw. Nauk. Uniw. Kardynała Stefana Wyszyńskiego ss. 206, il.

Instytut Archeologii.

449. NASZ uniwersytet - wspomnienia pracowników Uniwersytetu Warszawskiego. Red. prowadzący Anna Kędziorek, Beata Jankowiak-Konik. Warszawa 2016 Wydawnictwa Uniw. Warszawskiego ss. 559, il.

450. NAUKI ścisłe i przyrodnicze na Uniwersytecie Warszawskim. Red. nauk. Andrzej Kajetan Wróblewski. Warszawa 2016 Wydawnictwa Uniw. Warszawskiego ss. 832, il. (Monumenta Universitatis Varsoviensis 1816-2016).

Treść: Wróblewski A. K.: Przedmowa s. 13-17; Włodarczyk Jarosław: Astronomia s. 19-49; Majewski Tomasz: Nauki biologiczne s. 51-197; Lichocka Halina: Chemia s. 199-310; Wróblewski A. K.: Nauki fizyczne s. 313-484; Richling Andrzej: Geografia s. 487-543; Szulczewski Michał: Nauki geologiczne s. 545-669; Duda Roman: Matematyka s. 671-757; Śródka Andrzej: Nauki medyczne s. 759-793.

451. PARAFINIUK Jan: Dwa wieki nauk mineralogicznych na Uniwersytecie Warszawskim. Wybór il. Bogusław Bagiński. Warszawa 2016 Wydawnictwa Uniw. Warszawskiego ss. 203, il.

452. ZARYS dziejów Wydziału Prawa i Administracji Uniwersytetu Warszawskiego. Red. nauk. Grażyna Bałtruszajtys. Warszawa 2008 Wydaw. Prawnicze LexisNexis ss. 273, nlb. 1, il.

Toż. Wyd. 2. uzup. Warszawa 2016 Wolters Kluwer ss. 358, nlb. 3, il.

Treść: Rączka Krzysztof, Giaro Tomasz: Wstęp s. 5-7; Od Redakcji s. 9-10; Rosner Anna: Dzieje Wydziału Prawa i Administracji Uniwersytetu Warszawskiego w latach 1808-1831 s. 11-57; Paszkowska Marzenna: Wydział Prawa i Administracji Szkoły Głównej Warszawskiej (1862-1869) s. 59-91; Bosiacki Adam: Wydział Prawa Cesarskiego Uniwersytetu Warszawskiego w latach 1869-1915 s. 93-129; Battruszajtis G.: Wydział Prawa w latach 1915-1939 s. 131-212; Bałtruszajtis G.: Wydział Prawa w latach 1939-1944 s. 213-239; Izdebski Hubert: Wydział Prawa po roku 1945 s. 241-328; Bibliografia s. 329-347. 


\section{Uniwersytet Wileński}

453. GAWROŃSKA-GARSTKA Magdalena: Uniwersytet Stefana Batorego w Wilnie uczelnia ziem północno-wschodnich Drugiej Rzeczypospolitej (1919-1939) w świetle źródeł. Poznań 2016 Wydaw. Rys ss. 371.

454. PRZENIOSŁO Małgorzata: Profesorowie Wydziału Teologicznego Uniwersytetu Stefana Batorego w Wilnie 1919-1939. Acta Universitatis Wratislaviensis. No 3755: Wrocławskie Studia Wschodnie. [T.] 20: 2016 s. 85-99.

455. TOMASZEWSKI Patryk: Chór Akademicki Studentów Uniwersytetu Stefana Batorego w Wilnie w okresie dwudziestolecia międzywojennego. Muzyka. R. 61: 2016 nr 2 s. 111-116.

\section{Uniwersytet Wrocławski}

456. DOLATA Tomasz: Dziekani Wydziału Prawa Uniwersytetu we Wrocławiu w latach 1811-1911. Acta Universitatis Wratislaviensis. Prawo. Nr 321: 2016 s. 159-171.

\section{Wileńskie Seminarium Duchowne}

457. SZOT Adam: Likwidacja Wileńskiego Seminarium Duchownego w 1945 roku. Rocznik Teologii Katolickiej. T. 15: 2016 cz. 1 s. 238-248.

\section{Wojskowa Akademia Medyczna}

458. TUSZYŃSKI Wiesław Jan: Bez patosu i etosu. Wspomnienia podchorążego Drugiego Plutonu Szóstego Kursu Wojskowej Akademii Medycznej w Łodzi w latach 1963-1969. Lubiejew 2016 Wiesław Jan Tuszyński; Firma Sas, Wanda Tarnawska ss. 241, il.

\section{Wyższa Oficerska Szkoła Pożarnicza}

459. [TRZYDZIESTA piąta] 35. rocznica strajku w Wyższej Oficerskiej Szkole Pożarniczej. Wspomnienia. Aut. wspomnień Teofil Bogucki [i in.]. Warszawa 2016 Szkoła Gł. Służby Pożarniczej ss. 230, il.

$1981 \mathrm{r}$. 


\section{Wyższa Szkoła Ekonomiczna w Sopocie}

460. GŁUCHOWSKI Jan: Moje studia. Wyższa Szkoła Ekonomiczna w Sopocie 1957-1962. Gdańsk 2016 Wydaw. Uniw. Gdańskiego ss. 239, nlb. 2, il.

\section{Wyższa Szkoła Morska w Szczecinie}

461. WALCZAK Aleksander: Na szczecińskim szkolnym farwaterze. Wspomnienia rektora uczelni morskiej. Szczecin 2016 Akad. Morska ss. 182, nlb. 2, tabl. 48, il.

\section{Wyższa Szkoła Oficerska Sił Powietrznych}

462. MARCINIUK Andrzej: Kształcenie obserwatorów w dęblińskiej „Szkole Orląt” w latach 1925-1939. Dęblin 2016 Wydaw. Wyższej Szkoły Oficerskiej Sił Powietrznych ss. 79, nlb. 2. Wyższa Szkoła Oficerska Sił Powietrznych. Pracownia Historii Sztuki Wojennej. (Biblioteczka Lotnicza; t. 2).

Wyższa Szkoła Oficerska Wojsk Lądowych we Wrocławiu

463. NOWACKI Krzysztof: Wyższa Szkoła Oficerska Wojsk Lądowych we Wrocławiu. Przeszłość i teraźniejszość. Kwartalnik Bellona. [R. 9]: 2015 nr 3 s. 163-175.

Lata 1917-2015.

\section{BIOGRAFIE}

\section{Zbiory życiorysów}

464. GOŁDYN Piotr: Wkład Wielkopolan Wschodnich w rozwój oświaty w Polsce w pierwszej połowie XX wieku. Wybrane przypadki. Lubelski Rocznik Pedagogiczny. Vol. 35: 2016 no 4 s. $161-174$.

Wanda Haberkantówna (1871-1930), Stefania Sempołowska (1869-1944), Sławomir Czerwiński (1885-1931), Władysław Przanowski (1880-1937).

465. GRZEBIEŃ Ludwik, Topij-Stempińska Beata: Konwikt szlachecki w Tarnopolu 1856-1886. Słownik wychowanków. Kraków 2016 WAM ss. 349, il.

Rec.: Kochanowicz Jerzy, Przegląd Historyczno-Oświatowy. R. 59: 2016 nr 3/4 s. 262-265. 
466. HARCERSKI słownik biograficzny. T. 4. Pod red. Janusza Wojtyczy. Warszawa-Łódź 2016 Muzeum Harcerstwa; Marron ss. 272.

T. 1. 2006.

467. JARUSZEWSKI Kazimierz: Sławni i mniej znani. Sylwetki wychowanków Królewskiego Katolickiego Gimnazjum w Chojnicach (1815-1919). Chojnice 2015 Chojnickie Tow. Przyj. Nauk ss. 110, nlb. 2, il. (Biblioteka Chojnicka; t. 14).

468. LUDZIE bliscy i dalecy. T. 2: Biogramy postaci związanych z III LO im. Adama Mickiewicza w Katowicach. Red. Zbigniew Hojka, Aleksandra Różycka. Katowice 2016 III LO im. Adama Mickiewicza w Katowicach; Drukarnia Archidiec. ss. 260, nlb. 4, il.

Lata $1871-2016$.

469. „NIE ZGAŚNIE pamięć o waszej pracy”. Założyciele Uniwersytetu Poznańskiego. Pod red. Alicji Pihan-Kijasowej, Danuty Konieczki-Śliwińskiej. Poznań 2016 Wydaw. PTPN ss. 197, tabl. 24, il. PTPN, UAM w Poznaniu.

Józef Kostrzewski (1885-1969), Stanisław Kozierowski (1874-1949) - biografie.

470. NIEZWYKŁE biografie harcerskie Tczewa i Pomorza. Praca pod red. Jana Kulasa. Pelplin 2016 Bernardinum ss. 231, nlb. 1, il.

Lata $1867-2012$.

471. O ŚWIĘTOŚCI! Uniwersytet Jagielloński i jego święci wychowankowie. Kraków 2016 Muzeum UJ ss. 72, il.

Lata 1399-2005.

472. PORTRETY uczonych. Profesorowie Uniwersytetu Warszawskiego 1816-1915. Red. nauk. Marek Wąsowicz, Andrzej Kajetan Wróblewski. Warszawa 2016 Wydawnictwa Uniw. Warszawskiego ss. 536, il. (Monumenta Universitatis Varsoviensis 1816-2016).

473. PORTRETY uczonych. Profesorowie Uniwersytetu Warszawskiego 1915-1945. [T. 1:] A-Ł. Red. nauk. Piotr Salwa, Andrzej Kajetan Wróblewski. Warszawa 2016 Wydawnictwa Uniw. Warszawskiego ss. 497, il. (Monumenta Universitatis Varsoviensis 1816-2016).

Toż. [T. 2:] M-Ż. Warszawa 2016 ss. 449, il.

474. PORTRETY uczonych. Profesorowie Uniwersytetu Warszawskiego po 1945. [T. 1:] A-K. Red. nauk. Waldemar Baraniewski, Wojciech Tygielski, Andrzej Kajetan Wróblewski. Warszawa 2016 Wydawnictwa Uniw. Warszawskiego ss. 714, il. (Monumenta Universitatis Varsoviensis 1816-2016).

Toż. [T. 2]: L-R. Warszawa 2016 ss. 611, il.

Toż. [T. 3]: S-Ż. Warszawa 2016 ss. 690, il.

475. PRO MEMORIA. Profesorowie Uniwersytetu Jagiellońskiego spoczywający na Cmentarzu Rakowickim 1803-2015. [Cz.] 2. Pod red. Jana Wiktora Tkaczyńskiego. Kraków 2016 WUJ ss. 317 , nlb. 2 , il.

Cz. 1 pt.: Pro memoria. Profesorowie Uniwersytetu Jagiellońskiego spoczywający na Cmentarzu Rakowickim 1803-2013. Kraków 2014.

476. PROFESOROWIE Politechniki Krakowskiej 1945-2015. Pod red. Barbary Korty-Wyrzyckiej, Michała M. Stachowskiego. Kraków 2016 Wydaw. PK ss. 364, nlb. 3, il. Politech. Krakowska im. Tadeusza Kościuszki.

477. PROFESOROWIE Wydziału Nawigacyjnego Akademii Morskiej w Gdyni. Oprac. red. Małgorzata Sokołowska. Gdynia 2016 Oficyna Verbi Causa; na zlec. Wydz. Nawigacyjnego Akad. Morskiej ss. 161, il. 
478. PRZYWARA Jerzy, Leszczewicz Zbigniew, Pakuła-Kwiecińska Katarzyna]: Poczet profesorów Wydziału Geodezji i Kartografii Politechniki Warszawskiej. Wywiady przeprowadzili...; portrety wyk. Stanisław Nazalewicz. Warszawa 2016 Geodeta ss. 209, nlb. 3, il.

XX-XXI w.

479. SKRZYPEK Ewa: Poczet doktorów honoris causa. Wyd. 2. uzup. i rozsz. Warszawa 2016 Warszawski Uniw. Medyczny ss. XII, 420, nlb. 1, il.

Warszawski Uniwersytet Medyczny, XX-XXI w.

Wyd. 1. 2009.

480. STOGOWSKA Anna Maria: Edukatorzy. Wychowankowie szkoły płockiej zwanej „Małachowianką". Płock-Sierpc 2016 FERS Fund. Edukacji i Rozwoju Społ.; P.P.-H. Drukarnia ss. 196, il.

LO im. Marszałka Stanisława Małachowskiego w Płocku, lata 1788-1968.

481. W SŁUŻBIE nauki, wychowania i wartości. Szkice biograficzne o lubelskim środowisku naukowym. Red. Ryszard Skrzyniarz, Małgorzata Lobacz, Barbara Borowska. Lublin 2015 Wydaw. Episteme ss. 573, il. KUL. Wydz. Nauk Społ. (Biblioteka Katedry Biografistyki Pedagogicznej; 8).

Z treści: Skrzyniarz R.: Wstęp s. 11-18; Korzenie akademickiego Lublina: Skrzyniarz R.: Wyższe uczelnie Lublina, ich fundatorzy, założyciele, twórcy, pierwsi rektorzy s. 21-40; Gumińska Ilona: Lublin bogaty wiedzą. Mapa wyższych uczelni s. 43-48; Wawer Paulina: Zakład Teologiczny Zakonu Ojców Jezuitów w Lublinie Kolegium Bobolanum, czyli o kontemplacji w działaniu s. 49-63; Drogi do Lublina: Chodubski Andrzej: Wincenty Dawid (1816-1897) - pedagog, pisarz z lubelskiej przestrzeni kulturowej s. 67-80; Gołdyn Piotr: Przedlubelska działalność naukowa, społeczna i polityczna Witolda Chodźki [1875-1954] s. 81-95; Krynicka Tatiana: „Chciałabym służyć Ci z całego serca”. Droga profesor Leokadii Małunowiczówny 1910-1980] na Katolicki Uniwersytet Lubelski s. 97-118; Głogowska Helena: Białoruskie drogi profesora Teotyna Rott-Żebrowskiego [1919-2004] s. 121-160; Grabowska-Bacza Agata: Antoni Kość SVD [1949-2011] - nauczyciel, wychowawca (w Azji 1983-1993 i na Katolickim Uniwersytecie Lubelskim 1994-2011) s. 161-172; Środowiska lubelskich humanistów: Staroń Justyna: Feliks Araszewicz [1895-1966] jako naukowiec i pedagog - na marginesie wykładów z Dydaktyki literatury polskiej s. 175-184; Nastalska-Wiśnicka Joanna, Trojnacka Małgorzata: Ojciec Romuald Gustaw [1911-1976]: uczony - bibliotekarz - dyrektor - człowiek s. 185-214; Gajderowicz Magdalena: Profesor Andrzej Wojtkowski [1891-1975] - patriota, działacz, intelektualista s. 275-284; Wrzeszcz Maria: Człowiek służby do zatracenia. Profesor Zygmunt Sułkowski (1920-1995) s. 285-296; Żmudziak Magdalena: Stanisław Fita (1932-2011) - świadectwo, wspomnienie, echa działalności naukowej s. 297-306; Twórcy lubelskiej pedagogiki: Karczewska Joanna: Stefan Kunowski [1909-1977] - droga do Katolickiego Uniwersytetu Lubelskiego s. 345-352; Kowalczyk Agnieszka M.: Wychowywać dla Kościoła, życia i społeczeństwa, czyli o formacji uniwersyteckiej na Katolickim Uniwersytecie Lubelskim s. 363-379; Opozda Danuta, Parzyszek Magdalena: Zarys refleksji nad rozwojem pedagogiki rodziny na Katolickim Uniwersytecie Lubelskim Jana Pawła II w świetle koncepcji wychowania w rodzinie Piotra Poręby i Józefa Wilka s. 381-397; Kiereś Barbara: Feliks Wojciech Bednarski [1911-2006] jako rzecznik pedagogiki personalistycznej s. 399-405; Łobacz M.: Profesor Wojciech Chudy [1947-2007] - „wzór bohaterskiej fascynacji nauką”, nieoceniony mistrz i wychowawca s. 407-427; Walewander Edward: Pedagogia życia Franciszka Skowyry (1902-1978) s. 429-436; Kostkiewicz Janina: Krytyka warstwy wychowawczej totalitaryzmu komunistycznego lat dwudziestych i trzydziestych XX wieku w pismach Antoniego Szymańskiego s. 439-455; Rynio Alina: Refleksje nad osobą i dziełem Karola Wojtyły - Jana Pawła II w kontekście jego więzi z Katolickim Uniwersytetem Lubelskim s/ 457-471; Starnawski Witold: Filozofia i wychowanie. KUL i „kulowcy” - przełom lat siedemdziesiątych i osiemdziesiątych XX wieku s. 473-483; Chłodna-Błach Imelda: Ojciec profesor Mieczysław Albert Krąpiec [1921-2008] i lubelska szkoła filozoficzna s. 485-494; Stępień Katarzyna, Zawojska Teresa: Powszechna Encyklopedia Filozoficzna - „opus magnum” lubelskiej szkoły filozofii klasycznej s. 495-514; Absolwenci: Jabłońska Anna: „Uniwersytet Marii Curie-Skłodowskiej i ja” - znaczenie Lublina w życiu studentki z przełomu lat pięćdziesiątych i sześćdziesiątych XX wieku s. 517-533; Borowska B.: Absolwenci Katolickiego Uniwersytetu Lubelskiego w służbie „Bogu, ludziom i Ojczyźnie” s. 535-558; Rudenko Oleh: Pierwsi studenci niepodległej Ukrainy na Katolickim Uniwersytecie Lubelskim s. 559-573. 
482. ZASŁUŻENI dla harcerstwa 1916-1949. Skarżysko-Kamienna. Słownik biograficzny. T. 1. Pod red. Marcina Medyńskiego, Krzysztofa Zemeły. Skarżysko-Kamienna 2016 PIS Agencja Wydawniczo-Poligraficzna; staraniem Obwodu Świętokrzyskiego ZHP ss. 160, il.

\section{Poszczególne biografie}

483. SPYCHAŁA Zdzisław: W siedemdziesiątą rocznicę urodzin Zbyszka Adamskiego (1946-1993). Rocznik Wieluński. T. 16: 2016 s. 337-339.

Nauczyciel LO im. T. Kościuszki w Wieluniu.

484. BIELICKI Janusz: Marceli Bielicki [1845-1925] - jeden z dziewiętnastowiecznych pionierów szkolnictwa publicznego na ziemi płockiej i dobrzyńskiej. Nasze Korzenie. Nr 10: 2016 s. 46-48.

485. FALKOWSKA Joanna: W służbie edukacji kobiet. Działalność Felicji Boberskiej z Wasilewskich (1825-1889). Studia Paedagogica Ignatiana. Vol. 19: 2016 [nr] 3 s. 123-142.

486. DEJER Kazimierz Jan: Apostołka wiary, prawdy i wiedzy. Biografia Stanisławy Bojarskiej [1913-1999] założycielki Liceum Ogólnokształcącego w Horodle. Horodło 2016 Kazimierz Jan Dejer ss. 109, il.

487. BUKOWSKA-MARCZAK Ewa: Wychowawca protestantów. O postaci Szymona Budnego [1530-1593] w historiografii polskiej. Prace Naukowe Akademii im. Jana Dtugosza. Pedagogika. T. 25: $2015 \mathrm{nr} 1$ s. 659-667.

488. STAWIAK-OSOSIŃSKA Małgorzata: Adam Zygmunt Czyżewski (1841-1910) - zasłużony nauczyciel lwowskiej szkoły położniczej. Lubelski Rocznik Pedagogiczny. Vol. 35: 2016 no 4 s. $65-78$.

489. RADZIEWICZ-WINNICKI Andrzej: Smutek i żal. Pożegnanie z moim Przyjacielem. Chowanna. 2016 t. 1 s. $367-369$.

Kazimierz Denek (1932-2016).

490. SEROCZYŃSKI Marcin: Antoni Depczyński 1906-1914. Nauczyciel, harcerz, patriota. Chełmża-Wąbrzeźno 2016 ZHP. Hufiec Chełmża im. Antoniego Depczyńskiego; Wąbrzeskie Zakł. Graficzne ss. 76, il.

491. KOWOLIK Piotr: Edmund Bojanowski (1814-1871) pedagog i wychowawca, działacz oświatowo-narodowy i społeczno-religijny. Nauczyciel i Szkoła. 2016 nr 2 s. 307-311.

492. GRZYBOWSKI Michał Marian: Profesor Jadwiga Grzybowska 1928-2013. Płock -Sierpc 2014 P.P.-H. Drukarnia ss. 47, il.

493. SIUDA Maria: Józef Grzywna (1933-1994) - pedagog, badacz oświaty Kielecczyzny. Lubelski Rocznik Pedagogiczny. Vol. 35: 2016 no 4 s. 141-160.

494. MISZCZUK Marian: Zbigniew Adolf Heidrich 1899-1983. Człowiek, wychowawca, przedsiębiorca, naukowiec. Warszawa 2016 Fund. 20 ss. 151, il.

495. CZUB Robert: Stefan Jankowski [1934-1997] pedagog i regionalista, kustosz Muzeum w Gostyniu. Kronika Wielkopolski. 2016 nr 2 s. 71-74.

496. ROGOZIŃSKA Katarzyna: Tadeusz Joteyko [1872-1932] - muzyk, kompozytor, pedagog. Lubelski Rocznik Pedagogiczny. Vol. 35: 2016 no 4 s. 97-108. 
497. JANOWSKI Andrzej: Być dzielnym i umieć się różnić. Szkice o Aleksandrze Kamińskim [1903-1978]. Wyd. 4. rozsz. Warszawa 2016 Niezależne Wydaw. Harcerskie ss. 253, nlb. 2, il. Wyd. 1. 1992.

498. OBRĘBSKA Maria: Wychowawczyni miłośników przyrody. O Adeli Klein [1892-1979] nauczycielce Szkoły Powszechnej nr 3 w Siedlcach. Siedlce 2016 Bibl. Publ. im. Heleny Radlińskiej ss. 93, il.

499. KIERNIKOWSKI Paweł: Jan Andrzej Klekot (1936-2014). Scientific Bulletin of Chetm. Section of Pedagogy. 2015 nr 1 s. 175-177.

Nauczyciel.

500. RICHTER Manfred: Jan Amos Komeński [1592-1670]. Zarys życia i działalności. Siedlce 2015 Inst. Kultury Region. i Badań Liter. im. Franciszka Karpińskiego Stow.; przy współpr. Bibl. Jana Amosa Komeńskiego IKRiBL ss. 286, il. Inst. Neofilologii i Badań Interdyscyplinarnych Uniw. Przyrodniczo-Human. w Siedlcach. (Colloquia Litteraria Sedlcensia; t. 19).

501. PALUCHOWSKI Piotr: Henryk (Heinrich) Kühn (1690-1769) - wybitny matematyk, profesor Gdańskiego Gimnazjum Akademickiego. Przeglad Historyczno-Oświatowy. R. 59: 2016 nr $1 / 2$ s. 194-209.

502. SZYSZKA Bogdan: Kazimierz Lewicki (1882-1948). Zamojskie Studia i Materiaty. Ser. Pedagogika. T. 18: 2016 z. 1 s. 283-288.

Nauczyciel.

503. ...RZECZ o Mieczysławie Lipeckim [1903-1993]. Red. Bogdan Szykuła, Piotr Piela, Łukasz Zwolan, Renata Jastrzębska. Łabunie 2016 Bibl. Publ. Gm. Łabunie ss. 52, il. +1 dysk optyczny (CD). (Labuńska Biblioteka Regionalna; 19).

Nauczyciel.

504. ŻUBRZYCKA-MACIĄG Teresa: Życie i poglądy pedagogiczne profesora Mieczysława Lobockiego [1929-2012]. Rocznik Teologiczny. T. 63: 2016 z. 11 s. 177-189.

505. Żebrowski Mariusz: Teodora Maj (1882-1970). Rocznik Grudziadzki. T. 24: 2016 s. 227-234. Nauczycielka.

506. LUSEK Joanna: Istota wychowania w koncepcji błogosławionej Matki Marceliny Darowskiej [1827-1911] i jej współczesne implikacje. [W:] Kobiety na Kresach na przełomie XIX i XX wieku. Pod red. nauk. Adriany Dawid i Joanny Lusek. Warszawa 2016 s. 95-111.

507. KAROL Miarka. Działacz społeczny i oświatowy na Śląsku. W 190. rocznicę urodzin. Praca zbior. pod red. Danuty Kocurek. Pszczyna 2016 Starostwo Pow. ss. 99, il. +1 dysk optyczny (DVD).

Materiały z konferencji, Pszczyna, 14 IV 2015 r.

Z treści: Kocurek D.: Ziemia Pszczyńska w czasach Karola Miarki [1825-1882] s. 11-18; Kiełkowska Małgorzata: Pielgrzymowice - rodzinna miejscowość Karola Miarki s. 19-22; Kocurek D.: Karol Miarka nauczyciel i społecznik s. 23-29; Pisek Justyna, Waluszko Cezary: Spuścizna literacka Karola Miarki s. 30-45; Spyra Aleksandra, Kocurek D.: Drukarstwo na Ziemi Pszczyńskiej w XIX stuleciu, ze szczególnym uwzględnieniem działalności Karola Miarki s. 46-51; Pilis Andrzej: Czego Karol Miarka dziś by nauczał? s. 52-54; Szostak Maria: Przesłanie Karola Miarki dla współczesnej edukacji s. 55-60; Szostak M.: Edukacja regionalna w śląskiej szkole (szkic historyczny) s. 61-67; Kiełkowska M.: Działalność Stowarzyszenia Kulturalno-Społecznego Karola Miarki w Pielgrzymowicach s. 76-79; Tucka-Marek Agata: Sprawozdanie z konferencji popularnonaukowej „Karol Miarka - działacz zasłużony dla Śląska” s. 80-83; Pisek J., Waluszko C.: Bibliografia prac Karola Miarki s. 84-86; Literatura przedmiotu s. 86-99. 
508. WELKER Lesław J.: Leszek Ignacy Michalski (1920-1995), instruktor harcerski, żołnierz Armii Krajowej, nauczyciel akademicki, działacz społeczny. Rocznik Toruński. T. 43: 2016 s. 309-315.

509. MISIAK Małgorzata: Wspomnienie o Józefie Misiaku (1930-2013). In memoriam. Rocznik Wieluński. T. 16: 2016 s. 325-329.

Nauczyciel Liceum Pedagogicznego potem LO.

510. RADZISZEWSKA Maria: Losy uczestników strajku szkolnego 1905 roku na przykładzie biografii Tadeusza Młodkowskiego [1887-1960]. Rozprawy z Dziejów Oświaty. T. 53: 2016 s. 83-94.

511. SZTYLC Katarzyna Żaneta: The abbes Magdalena Mortęska [1554-1631] her life and reformist initiatives aimed at female education in the post-tridentine era. Roczniki Teologiczne. T. 63: 2016 s. 53-73.

512. SAPIA-DREWNIAK Eleonora: Kamilla Mrozowska (1917-2002) - nauczycielka uczona - mistrz. Przeglad Historyczno-Oświatowy. R. 59: 2016 nr 3/4 s. 209-222.

513. GOŁDYN Piotr: Mieczysława Zofia Nowaczykowa (1905-2002) - wielkopolska nauczycielka o wieluńskich korzeniach. Rocznik Wieluński. T. 16: 2016 s. 209-216.

514. PŁAWECKA Katarzyna: Świat wartości Zofii Oleksówny [1905-1966] - (nie)zwyczajnej polonistki. Rocznik Sądecki. T. 45: 2016 s. 121-144.

515. RACINOWSKI Dariusz: Józef Opic (1904-1988) nauczyciel, wychowawca i społecznik. Polonia Maior Orientalis. T. 3: 2016 s. 181-198.

516. GILEWSKA Weronika: Działalność patriotyczno-społeczna Marii Opieńskiej w latach 1911-1921. [W:] Kobiety na Kresach na przełomie XIX i XX wieku. Pod red. nauk. Adriany Dawid i Joanny Lusek. Warszawa 2016 s. 85-83.

517. KOSTRZEWSKI Andrzej: Stanisław Pawłowski (1882-1940). Poznań 2016 Wydaw. Nauk. UAM ss. 196. UAM. (Biografie Rektorów Uniwersytetu im. Adama Mickiewicza w Poznaniu).

518. TOPIJ-STEMPIŃSKA Beata: W trosce o młodzież. Stanisław Podolański SJ [1887-1945], pedagog (nie)znany. Lubelski Rocznik Pedagogiczny. Vol. 35: 2016 no 4 s. 109-120.

519. FARON Bolesław: Profesor. O Janie Rostockim [1925-2014] opowieść biograficzna. Rocznik Sadecki. T. 44: 2016 s. 188-219.

520. JANUSZ Sawczuk (1942-2016) długoletni nauczyciel Szkoły Podstawowej Nr 1 w Międzyrzecu Podlaskim, muzyk, plastyk, animator kultury. Rocznik Międzyrzecki. T. 45/46: 2016 s. $309-310$.

521. WOŹNIAK Jerzy: Druh Stagrowski i Jego Szczep Węzeł. Wyd. 2. rozsz. i uzup. Radzyń Podlaski 2016 Radzyńskie Stow. Inicjatyw Lokalnych ss. 139, il.

Mieczysław Stagrowski (1909-1986); ZHP.

522. WIERZBICKI Marek: Harcerz, żołnierz, obywatel. Zygmunt Lechosław Szadkowski (1912-1995). Lublin 2016 IPN-KŚZpNP. Oddz. ss. 254, nlb. 1, tabl. 41, il. IPN-KŚZpNP. Oddz. w Lublinie. (Centralny Projekt Badawczy IPN Polska Emigracja Polityczna 1939-1990).

523. MALINOWSKA Maria: Działalność oświatowa ks. Józefa Szafranka [1807-1874]. Podkarpackie Forum Filologiczne. 2011 s. 372-374. 
524. ŻERKO Józef: Dr Jerzy Teofil Szews (1925-2016) nauczyciel akademicki, biografista, badacz dziejów oświaty i wychowania Pomorza Gdańskiego. Biuletyn Historii Wychowania. [Nr] 34: 2016 s. $135-143$.

525. KAMIŃSKA Janina: „Szkoła - nauczyciel - wychowanie”; wokół jubileuszu profesor Ireny Szybiak. Przeglad Historyczno-Oświatowy. R. 59: 2016 nr 3/4 s. 223-237.

75-lecie urodzin w $2015 \mathrm{r}$.

526. ŻERKO Józef: 40-lecie posługi siostry dyrektor Jadwigi Rafaeli Targańskiej dzieciom specjalnej troski w Zespole Placówek Oświatowych „Nasz Dom” w Gębicach. Studia i Badania Naukowe - Ateneum Szkoła Wyższa w Gdańsku. R. 8: 2014 nr 1 s. 83-100.

527. FEDUSZKA Jacek: Aleksander Tarnawski (1884-1946) - pedagog, archiwista i historyk. Zamojskie Studia i Materiaty. Ser. Pedagogika. T. 18: 2016 z. 1 s. 277-282.

528. MEISSNER Andrzej: Tatomir Lucjan herbu Sas (1836-1901) - pedagog, geograf, historyk. Szkic do portretu. Studia i Prace Pedagogiczne. Nr 3: 2016 s. 167-181.

529. KACZMARSKI Krzysztof: Słownik biograficzny działaczy ruchu narodowego 1887-1990. Władysław Tutek „Słabiński” (1885-1951), nauczyciel, działacz Obozu Wielkiej Polski i Stronnictwa Narodowego, prezes Zarządu Okręgu Rzeszowskiego SN. Glaukopis. Nr 32: 2015 s. 306-311.

530. RZECZ o Michale Urbanku. Wybór i oprac. Dariusz Szczecina. Wyd. 2. rozsz.. Sopot 2016 ZHP. Chorągiew Gdańska. Hufiec im. Marynarki Wojennej ss. 44, il. (Biblioteczka stulecia sopockiego harcerstwa).

Michał Władysław Urbanek (1886-1982).

Wyd. 1. 1997.

531. WARZBIŃSKA Iwona: Stanisław Warzbiński [1903-1942]. Wspomnienie wnuczki. Rocznik Dobrzyński. T. 9: 2016 s. 187-190.

Nauczyciel.

532. MORACZEWSKA Barbara: Prekursorka instytucjonalnego wychowania małych dzieci w Polsce - Maria Weryho-Radziwillowiczowa (1858-1944). Studia Gdańskie. T. 12: 2015 s. 215-231.

533. SAMBORSKA-KUKUĆ Dorota: Działalność literacka i oświatowa Józefy Żdżarskiej [1826-1910]. Rekonesans. Rocznik Augustowsko-Suwalski. T. 16: 2016 s. 21-29.

\section{DZIEJE OŚWIATY POZASZKOLNEJ}

\section{Oświata dorosłych}

534. JAMROŻEK Wiesław: Uniwersytety ludowe w II Rzeczypospolitej (zarys problemu). Studia Paedagogica Ignatiana. Vol. 19: 2016 [nr] 2 s. 193-209.

535. JAWORSKA Agnieszka: Aksjologiczne założenia działalności katolickich uniwersytetów ludowych w Polsce w latach 1989-2004. Roczniki Pedagogiczne. T. 8: 2016 nr 4 s. 115-122.

536. [KIREJCZYK Andrzej]: ZDZ. Monografia. 1946-2016. Aut. tekstu ... Warszawa 2016 Zw. Zakładów Doskonalenia Zawodowego ss. 149, nlb. 3, il. Zw. Zakładów Doskonalenia Zawodowego.

Szkolenie zawodowe. 
537. WRONA-MERYK Izabela: Kursy zawodowe w Częstochowie w okresie dwudziestolecia międzywojennego. Prace Naukowe Akademii im. Jana Dlugosza. Pedagogika. T. 24: 2015 s. 627-639.

538. ZACKIEWICZ Grzegorz: Robotniczy Instytut Oświaty i Kultury im. Stefana Żeromskiego 1930-1939. Białystok 2016 Prymat, Mariusz Śliwowski ss. 237.

Utworzony w 1930 r. w Warszawie.

\section{Biblioteki}

539. CHMIELEWSKI Witold: Wyższe Studium Polskie przy Bibliotece Polskiej w Paryżu w 1945 r. Biuletyn Historii Wychowania. [Nr] 34: 2016 s. 57-90.

540. PIOTROWSKA Renata: Wykorzystanie oferty edukacyjnej biblioteki szkolnej przez nauczycieli przedmiotowych. Wyniki sondażu. Roczniki Biblioteczne. T. 60: 2016 s. 345-356.

541. PUGACEWICZ Iwona H.: Biblioteka Szkoły Polskiej w Batignolles jako filar narodowo-oświatowy Wielkiej Emigracji. Rozprawy z Dziejów Oświaty. T. 53: 2016 s. 149-166.

Zawiera też „Zdanie sprawy o stanie Biblioteki Szkoły Narodowej Polskiej w Batignolles do prześwietnej Rady administracyjnej tejże szkoły" z 4 II 1865 r., oprac. przez bibliotekarza Aleksandra Burbę.

542. SKŁODOWSKI Jan: Biblioteki dawnych szkół w Krzemieńcu. Dialog Dwóch Kultur. R, 11: 2016 z. 1 s. $129-138$.

Lata $1805-1969$.

\section{DZIEJE RUCHU NAUCZYCIELSKIEGO}

\section{Opracowania ogólne}

543. BOGUS Marzena: W drodze do społeczeństwa obywatelskiego. Rola związków nauczycielskich na Śląsku Austriackim w drugiej połowie XIX i na początku XX wieku. Wieki Stare i Nowe. T. 11: 2016 s. 96-113.

544. DURKA Jarosław: Pielgrzymki nauczycieli na Jasną Górę w latach 60. i 70. XX wieku w dokumentach Służby Bezpieczeństwa. Forum Pedagogiczne. 2016 nr 2 cz. 2 s. 161-175.

545. KAHL-ŁUCZYŃSKA Edyta: Działalność oświatowa Związku Nauczycielstwa Polskiego w okresie „propagandy sukcesu” (1970-1980). Przegląd Historyczno-Oświatowy. R. 59: 2016 nr $1 / 2$ s. $142-158$.

546. KASPRZAK Teresa: Tajna Organizacja Nauczycielska i jej rola w kształtowaniu polskości w czasie okupacji hitlerowskiej. Społeczeństwo Obywatelskie. R. 3: 2016 nr 1/2 s. 97-108.

547. SPYRA Janusz: Warunki rozwoju i działalności związków nauczycielskich w Europie Środkowej w 2. połowie XIX i na początku XX wieku. Prace Naukowe Akademii im. Jana Dlugosza. Pedagogika. T. 25: 2015 nr 2 s. 391-409.

548. WOJTYNKA Anna, Zimna Aldona: I Ogólnopolska Konferencja Naukowa „Życie codzienne nauczycieli w XIX i XX wieku. Związki i organizacje Nauczycielskie". Kalisz, 18-19 kwietnia 2016 r. Zeszyty Kaliskiego Towarzystwa Przyjaciót Nauk. Nr 16: 2016 s. 255-260. 


\section{Pamiętniki pedagogów}

549. BIEGAŃSKA Zofia: Z Ujazdowa jestem. Spojrzenie sentymentalne na lata 1946-1972. Warszawa-Bartoszyce 2016 Eagle Services ss. 142, il.

Wspomnienia pedagoga.

550. DZIADOSZ Marianna: Znajda. Rzeszów 2015 Podkarpacki Inst. Książki i Marketingu ss. 80, nlb. 4, il.

Wspomnienia nauczycielki (ur. 1943) w szkołach w Hucisku Jawornickim, Łopuszce Wielkiej i Strzeszowie.

551. EMINOWICZ Marek: Ścieżkami życia. Kraków 2015 Buchers Design ss. 127, nlb. 1, il. Wspomnienia nauczyciela historii w V LO w Krakowie, żyjącego w 1. 1933-2013.

552. GRZELAK Stanisław]: Notes wspomnień. Stanisława Grzelaka sentymentalna przechadzka „po Podrzecznej 30” z lat 1972-2011. Łowicz 2016 Zakł. Wielobranżowy Poligrafia ss. 24, il.

Wspomnienia nauczyciela z Zespołu Szkół Ponadgimnazjalnych nr 1 im. 10 Pułku Piechoty w Łowiczu.

553. WOLFRAMOWA Karolina z Dąbrowskich: Bieg życia mego. Pamiętnik lata 1830-1850. Red. Julia Skałecka. Warszawa 2016 Wydaw. Askon ss. 197, tabl. 2, il., mapy.

Toż. Pamiętnik lata 1850-1852. Red. Sylwia Chmura, J. Skałecka. Warszawa 2016 ss. 178, il.

Wspomnienia guwernantki (1830-1919).

\section{ORGANIZACJE MLODZIEŻOWE}

\section{Harcerstwo}

554. BADZIĄG Kazimierz Antoni: Był taki czas. Wspomnienia pomorskiego harcerza. Wyd. 3., popr. i uzup. Sztutowo-Gdynia 2016 Muzeum Stutthof; Region, Jarosław Ellwart ss. 167, il.

Toż w jęz. niem.: Es war eine Zeit. Erinnerungen eines Pfadfinders aus Pommerellen. 2. Aufl. Aus dm Pol. von Piotr Chruścielski. Sztutowo 2016 Muzeum Stutthof ss. 210, il.

Wyd. 1 (pol.). Warszawa 2009; wyd. 1 (niem.). Sztutowo 2013.

555. FRISZKE Andrzej: Związek Harcerstwa Polskiego 1956-1963. Społeczna organizacja wychowawcza w systemie politycznym PRL. Warszawa 2016 Inst. Studiów Polit. PAN; Wydaw. Krytyki Polit. ss. 310, nlb. 2. (Seria Historyczna; 24).

556. [GRODECKA Ewa]: Pierwsze ćwierćwiecze harcerstwa żeńskiego. Materiały do historii. Cz. 2: Służba wojenna I. W oprac. ... Kraków 2016 Impuls ss. 220, nlb. 4, il. ZHP. (Przywrócić Pamięć).

Toż. Cz. 3: Służba wojenna II. Kraków 2016 ss. 212, nlb. 4, il.

Podstawa ed.: Warszawa 1938.

557. GROMADZIŃSKI Stanisław: 20 lat Wspólnoty Seniorów ZHP im. ks. hm. Antoniego Bogdańskiego w Skulsku 1996-2016. Poznań 2016 Krąg Starszyzny Harcerskiej i Seniorów 2 PDH im. Kazimierza Wielkiego „Wiarusy” ss. 60, il. Krąg Starszyzny Harcerskiej i Seniorów 2 PDH im. Kazimierza Wielkiego „Wiarusy”.

558. HARCERSKIE słoneczne lata. Monografia 50 lat Harcerskiego Zespołu Artystycznego Słoneczni 1963-2013. Red. Wiesław Doniec [i inni]. Katowice 2016 Tow. Wspierania Twórczości Dziecięcej „Słoneczni”; Drukarnia Archidiec. ss. 191, il. 
559. IWANOWSKA Teresa: Harcerze łowiccy na międzynarodowym zlocie skautów w Gödölö na Węgrzech. Roczniki Łowickie. T. 13: 2016 s. 24-46.

$1933 \mathrm{r}$.

560. KADELA Agnieszka, Polan Dorota: Historia 130 Drużyny Starszoharcerskiej „Stu trzydziestu z Mucharza” im. Księcia Józefa Poniatowskiego. Rocznik Babiogórski. T. 17: 2016 s. 55-61.

Lata 1946-2016.

561. KLESSA Wojciech: Harcerskie ścieżki. Barcin-Inowrocław 2016 Nakł. aut.; Totem ss. 111 , il.

1. Wodna Drużyna Harcerska im. Adama Mickiewicza w Barcinie w 1. 1945-2016.

562. KORPAŁA Józef: Ideowość dzisiejszej młodzieży akademickiej a Starsze Harcerstwo. Kraków 2016 Impuls ss. 38, nlb. 6, il. (Przywrócić Pamięć).

Podstawa ed.: Kraków 1927.

563. KOZIMALA Irena: Harcerstwo - szkoła - społeczeństwo w południowo-wschodniej Polsce w latach 1911-1939. Studia Paedagogica Ignatiana. Vol. 19: 2016 [nr] 2 s. 145-170.

564. KSZTAŁCENIE starszyzny harcerek. Oprac. Wydz. Kształcenia Starszyzny Gł. Kwatery Harcerek. Kraków 2016 Impuls ss. 113, nlb. 7, il. (Przywrócić Pamięć).

Na podst. wyd.: Warszawa 1936.

565. KULIŃSKI Ireneusz: Harcerki i harcerze hufców Związku Harcerstwa Polskiego Skarżyska-Kamiennej i Suchedniowa. Szkice i materiały. Cz. 1. Skarżysko-Kamienna 2016 PTH. Oddz.; Starostwo Pow.; PIS, Agencja Wydawniczo-Poligraficzna ss. 334, il.

XX-XXI w.

566. KUTA Stefan: Rozważania harcerskie w dziecięciu gawędach. Kraków 2016 Impuls ss. 95, nlb. 5, il. (Przywrócić Pamięć).

Podstawa ed.: Wilno-Kraków 1920.

567. LUTOSŁAWSKI Kazimierz (pseud. Jan Zawada): Jak prowadzić pracę skautową. Wskazówki dla instruktorów skautowych oraz program pracy skautowej. (Zastosowanie do potrzeb młodzieży szkolnej). Kraków 2016 Impuls ss. 136, nlb. 8, il. (Przywrócić Pamięć).

Na podst. wyd.: Kraków 1913.

568. [MARCINIAK Józefa]: Organizacja harcerek na służbie w II Rzeczypospolitej. Wybrała i oprac. ... Tuchów 2016 Poligrafia Redemptorystów ss. 263, il.

569. MARSZAŁEK Katarzyna: Doktoraty i habilitacje z tematyki dotyczącej organizacji harcerskich w latach 1969-2016. [Cz. 1]. Studia z Teorii Wychowania. T. 7: 2016 nr 2 s. 199-226.

Toż. Cz. 2. Tamże nr 3 s. 207-244.

570. MARSZAŁEK K.: Dziedzictwo, którego nie można odrzucić. Próba interpretacji wybranych źródeł z lat 1918-2015 do dziejów Związku Harcerstwa Polskiego. Kraków 2016 Oficyna Wydawnicza „Impuls” ss. 303, il.

571. O CHRZEŚCIJAŃSKI i polski charakter harcerstwa. Sprawozdanie z procesu redaktora odpowiedzialnego „Strażnicy Harcerskiej” w Sądzie Okręgowym w Warszawie w dniach 1 grudnia 1934 r. i 28/29 marca 1935 r. Kraków 2016 Oficyna Wydawnicza „Impuls” ss. 164, nlb. 8, il. (Przywrócić Pamięć).

Na podst. wyd.: Warszawa 1935.

572. PAŁKA Elżbieta: Historia I Wodnej Drużyny Harcerskiej im. Adama Mickiewicza w Barcinie 1916-2016. Barcin 2016 Klub Żeglarski „Neptun” ss. 263, il. 
573. PAWEŁEK Alojzy: Gawędy instruktorskie. Zbiór tematów przeznaczonych dla starszej młodzieży harcerskiej i kierowników. Kraków 2016 Impuls ss. 118, nlb. 8. (Przywrócić Pamięć).

Na podst. wyd.: Poznań 1920.

574. PIĘCIAK Krzysztof: Miejsce egzekucji w krakowskich Krzesławicach a konspiracyjne harcerstwo. Krakowski Rocznik Historii Harcerstwa. T. 12: 2016 s. 5-11.

575. POD znakiem harcerskim. Stanisław Szumski [1895-1915]. Harcerz - legionista. Przerobił na podst. książki Bolesława Pochmarskiego pt. „Nowe pokolenie” i wyd. Jan Szumski. Kraków 2016 Impuls ss. 67, nlb. 13, il. (Przywrócić Pamięć).

Podstawa ed.: Lwów-Warszawa 1935.

576. PRZEKOP Przemysław: „Ku szczytom ideałów”. Refleksja o harcerskim życiu. Ełk 2016 Adalbertinum ss. 79.

577. RADICA Aleksander: Środowisko harcerskie w Zdołbunowie. Krakowski Rocznik Historii Harcerstwa. T. 12: 2016 s. 13-17.

578. ROCZNIK harcerski. Zawiera zbiór przepisów obowiązujących w Związku Harcerstwa Polskiego. Red. Stanisław Sedlaczek. Kraków 2016 Impuls ss. XXVIII, 391, nlb. 13, il. (Przywrócić Pamięć).

Podstawa ed.: Warszawa 1928.

579. SEDLACZEK Stanisław: Gawędy o prawie harcerskim. [Cz.] 1: Na słowie harcerza polegaj jak na Zawiszy. Współpr. wyd. Marian Miszczuk. Kraków 2016 Impuls ss. 45, nlb. 7, il. (Przywrócić Pamięć).

Toż. [Cz.] 3: Harcerz służy Bogu. Warszawa 2016 ss. 73, nlb. 3, il.

Podstawa ed.: Warszawa 1932.

580. [SEDLACZEK S.]: Przeglądy i pokazy harcerskie. Musztra harcerska z 60 rysunkami w tekście. Wg Andrzeja Małkowskiego i in. oprac. ... Kraków 2016 Impuls ss. 110, nlb. 6, il. (Przywrócić Pamięć).

Podstawa ed.: Poznań [i in.] 1931.

581. SOSNOWSKI Józef: Polska w wychowaniu harcerskim. Kraków 2016 Impuls ss. 159, nlb. 5, il. (Przywrócić Pamięć).

Podstawa ed.: Warszawa 1934.

582. SOSNOWSKI J.: Wytyczne programowe pracy zastępów chłopców starszych. Kraków 2016 Impuls ss. 135, nlb. 4, il. (Przywrócić Pamięć).

Podstawa ed.: Warszawa 1936.

583. SZCZECINA Dariusz: Harcerski Klub Sportowy Sopot i jego następcy. Sopot 2016 ZHP. Chorągiew Gdańska. Hufiec im. Marynarki Wojennej ss. 64, il. (Biblioteczka Stulecia Sopockiego Harcerstwa).

584. TWORKOWSKA[-SZYMAŃSKA] Janina: Równajmy krok. O współpracy z Ruchem Harcerskim Nauczycielstwa i Rodziców. Kraków 2016 Impuls ss. 137, nlb. 7, il. (Przywrócić Pamięć).

Podstawa ed.: Warszawa 1931.

585. UDZIAŁ harcerstwa w odzyskaniu i zachowaniu niepodległości Polski na przestrzeni dziejów. Pod red. Ewy Fogelzang-Adler i Janusza Wojtyczy. Kraków 2016 Komisja Hist. ZHP Chorągwi Krakowskiej ss. 270, nlb. 1, il. 
Treść: Wojtycza J.: Wstęp s. 5-8; Lipiec Józef: Wartość niepodległości s. 9-23; Wojtycza J.: Olga i Andrzej Małkowscy jako wzory osobowe harcerstwa s. 25-36; Perzanowski Tadeusz: Przemilczane epizody z historii harcerstwa i służby krakowskich harcerzy dla niepodległości Polski s. 37-53; Stefaniak Ryszard:, Pluskota Magdalena: Harcerstwo częstochowskie w walkach o granice Polski odrodzonej i zachowanie niepodległości s. 55-78; Prawdzic-Włodek Leszek Marian: Geneza i walka przemyskiego harcerstwa o niepodległość Rzeczypospolitej Polskiej i jej obronę, w XX wieku s. 79-95; Szymańska Marta: Przyczynek do oceny do udziału harcerek krakowskich w odzyskaniu niepodległości na podstawie wybranych źródeł s. 97-112; Dąbrowski Stanisław Jan: Udział harcerzy Lublina w odzyskaniu niepodległości i zachowaniu niepodległości Polski na przestrzeni dziejów s. 113-150; Szypulska-Kamyk Lucyna: Wychowanie w ZHP w duchu narodowym i państwowym w II Rzeczypospolitej s. 151-161; Marszałek Katarzyna: ZHP jako stowarzyszenie wychowujące obywateli dla Polski w latach 1918-1939, 1945-1950, 1956-1989 s. 163-179; Kozimala Irena: Szare Szeregi w Chorągwi Lwowskiej w latach 1939-1941 s. 181-199; Jaczewski Andrzej: „Szare Szeregi” w Milanówku s. 201-206; Łesyk Michał: Działalność harcerzy Hufca Kraków-Podgórze w okresie II wojny światowej s. 207-229; Fogelzang-Adler Ewa: Problemy wojenno-okupacyjne młodzieży i wizja niepodległej Polski na łamach prasy krakowskich Szarych Szeregów (1939-1945) s. 231-248; Miszczuk Marian: Harcerze w I Dywizji Pancernej 1942-1947 s. 249-266.

586. WRÓBLEWSKI Wojciech: Szczep Puszcza im. Kazimierza Wielkiego w Niepołomicach - przyczynek do historii harcerstwa niepokornego. W 40 rocznicę powstania. Krakowski Rocznik Historii Harcerstwa. T. 12: 2016 s. 19-45.

Zał. w 1976 r.

2. Inne

587. BIERNACKI Leszek: Jak powstał pierwszy NZS. Więź. R. 59: 2016 nr 4 s. 78-94.

Niezależne Zrzeszenie Studentów.

588. Dworaczek Kamil: Niezależne Zrzeszenie Studentów 1980-1981. Wrocław 2016 Oddz. IPN-KŚZzNP ss. 506, il. (Centralny Projekt Badawczy IPN Opozycja w Polsce 1976-1989. Encyklopedia Solidarności).

589. KOZŁOWSKA Magdalena: Świetlana przyszłość? Żydowski Związek Młodzieży Cukunft wobec wyzwań międzywojennej Polski. Kraków-Budapeszt 2016 Austeria ss. 346, nlb. 29, il. (Polscy Żydzi. Studia i teksty; 2).

590. RASZEJA Stefan: Akademickie Koło Pomorzan w Poznaniu pierwsza powojenna próba integracji Kociewiaków. Rydwan. Nr 6: 2011 s. 107-114.

Lata 1946-1948.

591. RĘDZIŃSKI Kazimierz: Towarzystwo Dom Zdrowia uczącej się młodzieży polskiej „Pomoc Bratnia" w Zakopanem (1900-1918). Prace Naukowe Akademii im. Jana Dtugosza. Pedagogika. T. 24: 2015 s. $505-522$.

592. ZASĘPA Henryk: Akademickie Koło Łowiczan. Roczniki Łowickie. T. 13: 2016 s. 163-192. W 1. 1921-1933. 